\title{
Archeological Impact Evaluations and Surveys in the Texas Department of Transportation's Bryan, Corpus Christi, San Antonio, and Yoakum Districts, 2000-2001
}

Ross C. Fields

Prewitt and Associates, Inc.

Karl W. Kibler

Cross Timbers Geoarcheological Services

E. Frances Gadus

Prewitt and Associates, Inc.

Amy M. Holmes

Prewitt and Associates, Inc.

Follow this and additional works at: https://scholarworks.sfasu.edu/ita

Part of the American Material Culture Commons, Archaeological Anthropology Commons, Environmental Studies Commons, Other American Studies Commons, Other Arts and Humanities Commons, Other History of Art, Architecture, and Archaeology Commons, and the United States History Commons

Tell us how this article helped you.

This Article is brought to you for free and open access by the Center for Regional Heritage Research at SFA ScholarWorks. It has been accepted for inclusion in Index of Texas Archaeology: Open Access Gray Literature from the Lone Star State by an authorized editor of SFA ScholarWorks. For more information, please contact cdsscholarworks@sfasu.edu. 


\section{Archeological Impact Evaluations and Surveys in the Texas Department of Transportation's Bryan, Corpus Christi, San Antonio, and Yoakum Districts, 2000-2001}

Creative Commons License

(C) $(1) \Theta \Theta$

This work is licensed under a Creative Commons Attribution-NonCommercial-No Derivative Works 4.0 International License. 


\title{
ARCHEOLOGICAL IMPACT EVALUATIONS AND SURVEYS IN THE TEXAS DEPARTMENT OF TRANSPORTATION'S BRYAN, CORPUS CHRISTI, SAN ANTONIO, AND YOAKUM DISTRICTS, 2000-2001
}

\author{
by \\ Ross C. Fields \\ Karl W. Kibler \\ E. Frances Gadus \\ and \\ Amy M. Holmes \\ with Contributions by \\ Christopher W. Ringstaff
}

Principal Investigator: Ross C. Fields

REPORTS OF INVESTIGATIONS, NUMBER 133

Prewitt and Associates, Inc. Cultural Resources Services Austin, Texas

ARCHEOLOGICAL STUDIES PROGRAM, REPORT NO. 35

Texas Department of Transportation

Environmental Affairs Division

February 2002

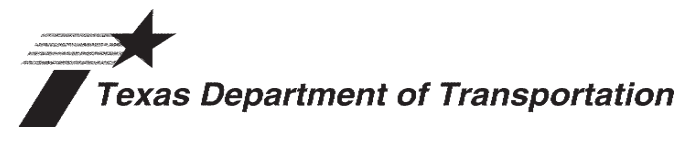




\title{
ARCHEOLOGICAL IMPACT EVALUATIONS AND SURVEYS IN THE TEXAS DEPARTMENT OF TRANSPORTATION'S BRYAN, CORPUS CHRISTI, SAN ANTONIO, AND YOAKUM DISTRICTS, 2001-2002
}

\author{
Copyright (C) 2002 \\ Texas Department of Transportation (TxDOT)
}

TxDOT owns all rights, title, and interest in and to all data and other information developed for this project. Brief passages from this publication may be reproduced without permission provided that credit is given to TxDOT. Permission to reprint an entire chapter, section, figures or tables must be obtained in advance from the Supervisor of the Archeological Studies Program, Environmental Affairs Division, Texas Department of Transportation, 125 East $11^{\text {th }}$ Street, Austin, Texas, 78701. Copies of this publication have been deposited with the Texas State Library in compliance with State Depository requirements.

Printed by TxDOT, Austin, Texas

On acid-free, $60 \mathrm{lb}$. paper

January 2002

jointly published by the

Texas Department of Transportation

Environmental Affairs Division

Archeological Studies Program

Nancy A. Kenmotsu, Ph.D., Supervisor

Archeological Studies Program Report No. 35

A. McGraw, Series Editor

and

Prewitt and Associates, Inc.

Cultural Resources Services

Austin, Texas

Reports of Investigations, No. 133 


\section{TABLE OF CONTENTS}

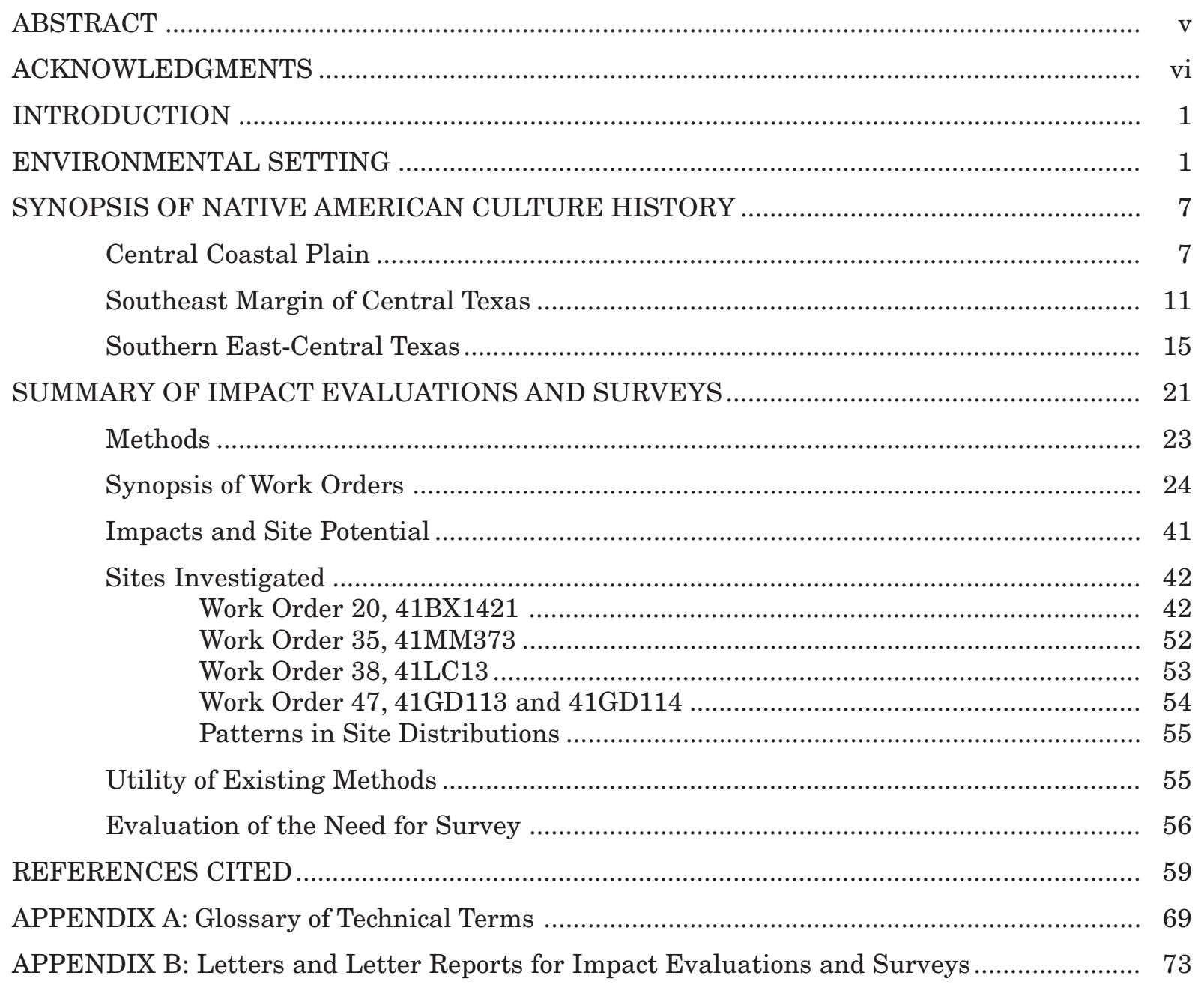




\section{LIST OF FIGURES}

1. Locations of the Bryan, Corpus Christi, San Antonio, and Yoakum Districts in

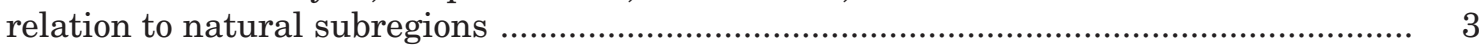

2. Major drainages in the Bryan, Corpus Christi, San Antonio, and Yoakum Districts ....... 5

3. Map of the study area showing the locations of all Impact Evaluations and Surveys ..... 22

4. Schematic cross section of a bridge approach showing common disturbance factors....... 42

\section{LIST OF TABLES}

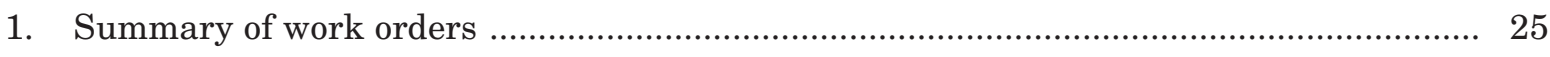

2. Summary of existing impacts by work order ........................................................... 43

3. Summary of archeological sites investigated ........................................................... 52 


\begin{abstract}
This document constitutes the final report of work done by Prewitt and Associates, Inc. (PAI), under a contract from the Texas Department of Transportation (TxDOT) to provide archeological services in four TxDOT districts-Bryan, Corpus Christi, San Antonio, and Yoakumin east-central and south-central Texas. Under this contract, PAI completed Impact Evaluations and Surveys to assist TxDOT in meeting the requirements of their Memorandum of Understanding with the Texas Historical Commission and a Programmatic Agreement between the Advisory Council on Historic Preservation, the Federal Highway Administration, the Texas Historical Commission, and TxDOT. The contract began on 8 February 2000 and concluded on 8 February 2002. During these two years, 46 work orders were completed.

The 46 work orders consisted of 71 Impact Evaluations, 20 Surveys, 5 Surveys with Geoarcheological Evaluations, and 1 work order to produce this report. Combined, these work orders entailed efforts at 58 bridge replacements, 16 projects involving primarily road widening or realignment, and 1 project consisting of creation of a wetland mitigation area. During completion of these work orders, five newly discovered or previously recorded archeological sites were investigated.

Fifteen of the Impact Evaluations led to a recommendation that an archeological survey be completed before construction. The remaining 56 Impact Evaluations resulted in a recommendation that no survey be required based on the extent of disturbance and the limited potential for sites with good integrity. Three of the Surveys investigated sites that were recommended for testing to assess eligibility for listing in the National Register of Historic Places and designation as State Archeological Landmarks. The other 22 Surveys either did not find any archeological sites or investigated sites that could be assessed as ineligible for National Register listing and State Archeological Landmark designation using the survey data.
\end{abstract}




\section{ACKNOWLEDGMENTS}

A number of people contributed to the successful completion of this project. Al McGraw managed the contract for the Archeology Studies Program, Environmental Affairs Division, Texas Department of Transportation, with the oversight of Nancy Kenmotsu and the assistance of Steve Ahr, Tim Meade, and Cynthia Tennis. At Prewitt and Associates, Ross C. Fields served as Principal Investigator, and Douglas K. Boyd was the Quality Control Officer. Amy M. Holmes, E. Frances Gadus, and Christopher W. Ringstaff served as Project Archeologists, and Ms. Holmes also filled the position of Project Geoarcheologist. These people performed most of the fieldwork and were responsible for writing most of the reports on individual work orders included as Appendix B; the site descriptions included in the body of the report are extracted from the work order reports. Karl W. Kibler prepared the Environmental Setting section of the report and one of the culture history summaries (Southeast Margin of central Texas); Ms. Gadus wrote one of the other summaries (Central Coastal Plain); and Ms. Holmes compiled Tables 1 and 2. Mr. Fields wrote the remainder of the report. Support at Prewitt and Associates was provided by Karen M. Gardner (laboratory supervision, photograph cataloging, and curation); Brian J. Wootan and Sandra L. Hannum (production of graphics); and Audra L. Pineda and Jane Sevier (report editing and production). 


\section{INTRODUCTION}

This document constitutes the final report of work done by Prewitt and Associates, Inc. (PAI), under a contract (P.O. No. C442000027194000) from the Texas Department of Transportation (TxDOT) to provide archeological services in four TxDOT districts-Bryan, Corpus Christi, San Antonio, and Yoakum-in east-central and south-central Texas. The contract began on 8 February 2000 and concluded on 8 February 2002. During those two years, 45 work orders for fieldwork were completed, with the final one issued in early September 2001 so that the draft version of this report could be submitted in November 2001, allowing time for review and revisions before the end of the contract.

Under this contract, PAI completed Impact Evaluations and Surveys to assist TxDOT in meeting the requirements of their Memorandum of Understanding with the Texas Historical Commission and a Programmatic Agreement between the Advisory Council on Historic Preservation, the Federal Highway Administration, the Texas Historical Commission, and TxDOT. TxDOT defines Impact Evaluations as "on-site inspection. . documenting existing impacts or other conditions which may preclude the presence of intact archeological deposits within the project area for a proposed Transportation Activity." Impact Evaluations are thus an initial step to determine whether survey of a particular area is warranted, given the anticipated effects of the project, the existing level of disturbance, and the likelihood of archeological deposits in good context.

TxDOT defines surveys as "archeological field work. . .of a proposed Transportation Activity to locate archeological remains, if any, including on-foot examination of the surface, shovel testing, and subsurface trenching by mechanical means where appropriate." As described below, PAI completed 45 work orders involving 71 Impact Evaluations and 25 Surveys. Five of the surveys included geoarcheological evaluations, and 20 did not. Most of these projects focused on replacing bridges and on country and farm-to-market roads. Other kinds of Transportation Activities included widening roads, constructing new bypasses, and creating a wetland mitigation area.

The body of this report consists of three major sections. A brief characterization of the environmental setting of the four TxDOT districts follows this introduction. Three brief synopses of Native American culture histories are presented next. One deals with the central Texas coast and adjoining coastal plain and encompasses the Corpus Christi District and most of the Yoakum District, one covers the southeast margin of central Texas and applies to most of the San Antonio District, and one is for the southern part of east-central Texas and covers the Bryan District and the northern part of the Yoakum District. The third section summarizes the work done under this contract. It discusses the methods employed in the Impact Evaluations and Surveys and evaluates their effectiveness. It also presents tables listing the Impact Evaluations and Surveys and their topographic and geologic settings, soils, land use, vegetation, and presence or absence of archeological sites. The sites investigated are described, and the existing disturbances that affect the potential of project areas to contain sites with sufficient integrity to be eligible for National Register of Historic Places listing or State Archeological Landmark designation are listed and discussed. The third section also provides an evaluation of the need for survey based on the results of this project. A references cited section and two appendixes follow the body of the report. Appendix A is a glossary of technical terms, and Appendix $\mathrm{B}$ (on CD-ROM) contains the letters and reports submitted to TxDOT for all Impact Evaluations and Surveys done under the contract.

\section{ENVIRONMENTAL SETTING}

The Bryan, Corpus Christi, San Antonio, and Yoakum Districts cover a 43-county area in east-central and south-central Texas and along the central Texas coast. Most of the fourdistrict area lies within the Gulf Coastal Plain physiographic province, its inland (western) edge hinging on the southern and eastern margins of the Edwards Plateau of the Great Plains province (Fenneman 1931, 1938). The intersection of these two physiographic provinces has been the scene of an interesting and dynamic geologic history (see Spearing 1991).

Geologically, the San Antonio District straddles a deep-seated fracture zone and site of past orogenic events that separates the stable continental interior to the west from the subsiding 
Gulf basin to the east and southeast. During the Cretaceous period as the Gulf of Mexico formed, clastic sediments and carbonates were deposited along the broad marginal shelf of the Gulf basin. These Lower Cretaceous sandstones and limestones found throughout the dissected margins of the Edwards Plateau represent cycles of marine transgression and regression. By upper Cretaceous times, infilling of the Gulf basin and shoreline progradation predominated, as Upper Cretaceous sandstones and mudstones throughout the central portion of the San Antonio District show. Marine regression and shoreline progradation continued during the Tertiary and Quaternary and are represented by various sandstone and mudstone units present throughout all four districts.

The different rock units have a major influence on the topography, flora, and hydrology across the four-district area. Five different natural regions lie within the area, due in part to these lithological variations (Figure 1). Encompassed within these are 10 subregions: the Oak Woodlands of the Oak Woods and Prairies region; the Blackland Prairie of the Blackland Prairies region; the Dunes/Barrier, Estuarine Zone, and Upland Prairies and Woods of the Gulf Coast Prairies and Marshes region; the Coastal Sand Plains, the Brush Country, and the Bordas Escarpment of the South Texas Brush Country region; and the Live Oak-Mesquite Savanna and the Balcones Canyonlands of the Edwards Plateau region (LBJ School of Public Affairs 1978).

The Oak Woodlands subregion covers most of the Bryan District and smaller portions of the San Antonio and Yoakum Districts. The Blackland Prairie subregion covers parts of the Bryan, San Antonio, and Yoakum Districts. The Dunes/Barrier, Estuarine Zone, and Upland Prairies and Woods subregions are limited to the Corpus Christi and Yoakum Districts, and the Coastal Sand Plains are limited to the southern part of the Corpus Christi District. The Brush Country and Bordas Escarpment subregions cover the western Corpus Christi and southern San Antonio Districts, and the Live Oak-Mesquite Savanna and the Balcones Canyonlands are limited to the northern and western parts of the San Antonio District.

The modern plant communities vary from subregion to subregion across the four-district area (see Diamond et al. 1987). Diamond et al.
(1987:205) classify these plant communities by their dominant growth form (e.g., trees, shrubs, grasses, graminoids, or forbs). They recognize forests (tree canopy cover $\geq 61$ percent), woodlands (tree canopy cover 26-60 percent), shrublands (communities of $0.5-3.0$-m-tall shrubs with a canopy cover $\geq 26$ percent), herbaceous communities ( $<25$ percent canopy cover of woody plants) consisting of grassland- and forb-dominated communities, swamps (arboreal-dominated wetlands), and marshes (herbaceous-dominated wetlands). The Oak Woodlands subregion consists of deciduous forests of overcup oak (Quercus lyrata), post oak (Q. stellata), and black hickory (Carya texana) and woodlands of bluejack oak (Q. incana), pine (Pinus sp.), blackjack oak (Q. marilandica), and post oak, as well as bogs of Sphagnum sp. and Rhynchospora sp. and marshes of gulf cordgrass (Spartina spartinae) and rushes and sedges (Juncus sp.).

The Blackland Prairie consists of tall grasslands (dominants $\geq 1 \mathrm{~m}$ tall) comprised of little bluestem (Schizachyrium scoparium), Indiangrass (Sorghastrum nutans), gamagrass (Tripsacum dactyloides), switchgrass (Panicum virgatum), and silveanus dropseed (Sporobolus silveanus). Riparian deciduous forests are of hackberry (Celtis laevigata), elm (Ulmus sp.), overcup oak, post oak, and black hickory.

In the Dunes/Barrier subregion, tall grasslands of seacoast bluestem (S. scoparium var. littoralis), forb-dominated communities of cenicilla (Sesuvium portulacastrum) and beach morning glory (Ipomoea stolonifera), and marshes of marshhay cordgrass (S. patens), smooth cordgrass ( $S$. alterniflora), gulf cordgrass, and rushes and sedges prevail. The Estuarine Zone also consists of marshes of the same cordgrass, rush, and sedge species. The Upland Prairies and Woods subregion consists of forests of water oak (Q. nigra) and live oak (Q. virginiana); woodlands of pecan (C. illinoensis), mesquite (Prosopis glandulosa), huisache (Acacia farnesiana), post oak, and live oak; tall grasslands of brownseed paspalum (Paspalum plicatulum), little bluestem, Indiangrass, gamagrass, and switchgrass; marshes of gulf cordgrass, marshhay cordgrass, rushes, and sedges; and swamps of buttonbush (Cephalanthus occidentalis). The Coastal Sand Plains are dominated by evergreen woodlands of live oak and seacoast bluestem, tall grasslands of seacoast bluestem, and marshes of 


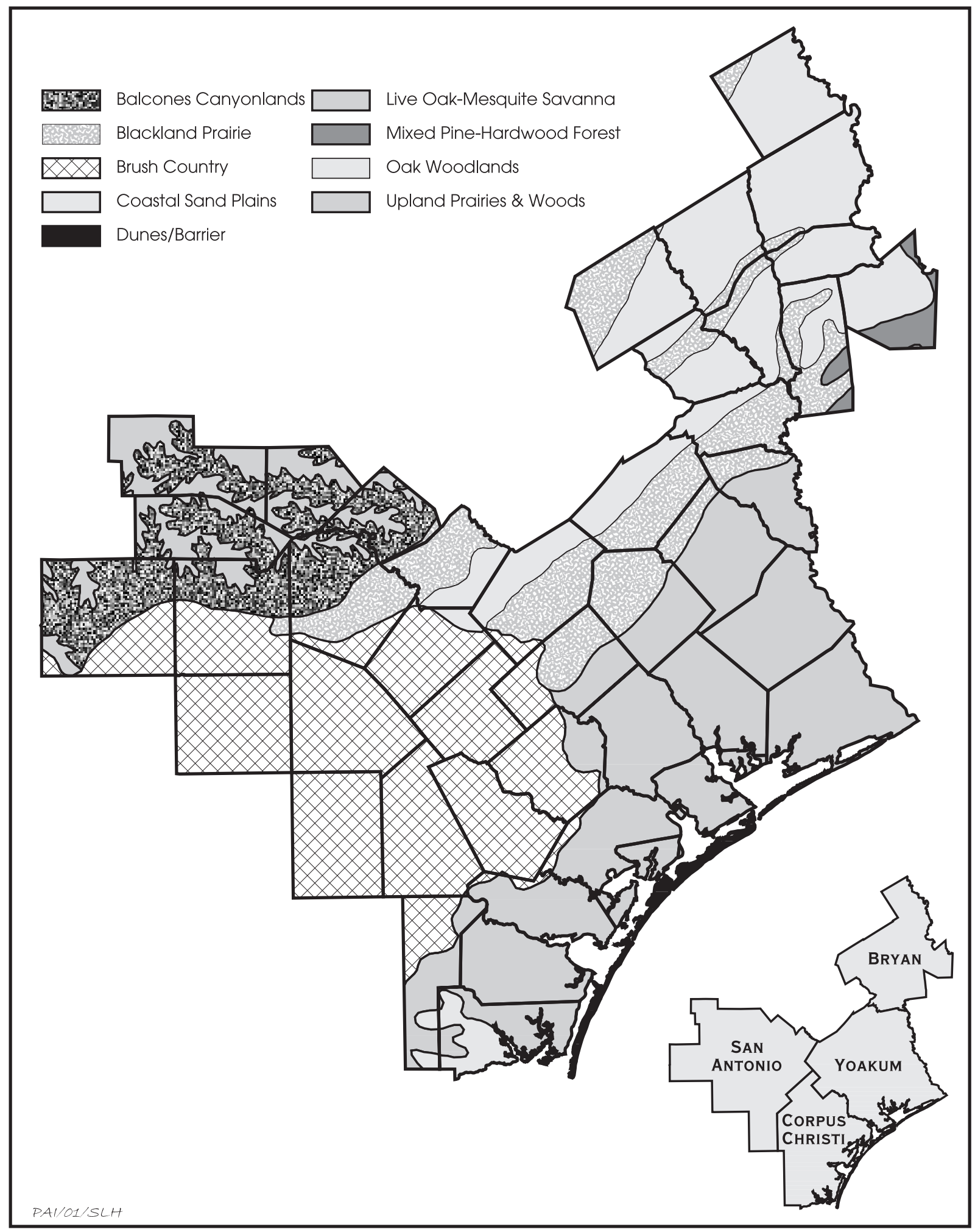

Figure 1. Locations of the Bryan, Corpus Christi, San Antonio, and Yoakum Districts in relation to natural regions. 
saltgrass (Distichlis spicata), gulf cordgrass, rushes, and sedges.

The Brush Country subregion consists of deciduous forests of hackberry and elm, woodlands of mesquite and huisache, and deciduous shrublands of blackbrush (Acacia rigidula) and fern acacia ( $A$. berlandieri). Evergreen shrublands of ceniza (Leucophyllum frutescens) and medium grasslands (dominants $0.5-1.0 \mathrm{~m}$ tall) of cane bluestem (Bothriochloa barbinodis) and mesquite are also part of the Brush Country floral community. Deciduous shrublands of fern acacia dominate the plant community of the Bordas Escarpment subregion.

The Live Oak-Mesquite Savanna subregion of the Edwards Plateau consists of deciduous forests of hackberry and elm and deciduous and evergreen woodlands of Lacey oak (Q. glaucoides), ashe juniper (Juniperus ashei), and live oak. Grasslands are also part of the floral community and consist of medium-tall grasslands of curly mesquite (Hilaria belangeri) and sideoats grama (Bouteloua curtipendula) and short grasslands (dominants $<0.5 \mathrm{~m}$ ) of blue grama (B. gracilis), buffalo grass (Buchloe dactyloides), and tobosa grass (H. mutica). The plant community of the Balcones Canyonlands consists of deciduous forests of bald cypress (Taxodium distichum), sycamore (Platanus occidentalis), hackberry, and elm and evergreen and deciduous woodlands of Texas oak (Q. texana), ashe juniper, live oak, and Lacey oak.

The major drainages within the four-district area are the Trinity, Brazos, Colorado, Guadalupe, San Antonio, and Nueces Rivers (Figure 2). Along the Texas coast, several smaller rivers and their basins separate these larger drainage basins. They include the San Bernard, Navidad, Mission, and Aransas Rivers. The Trinity River enters the Bryan District at Freestone County and flows southeast along the eastern edge of the Bryan District. It leaves the district as it enters Lake Livingston and exits Walker County. The Trinity River floodplain averages $5-6 \mathrm{~km}$ in width along this stretch and is flanked by large segments of Pleistocene-age terraces (Proctor et al. 1970; Shelby et al. 1968a, 1968b). Holocene alluvium is also mapped along several of the larger tributaries of the Trinity River, including Richland Creek, Tehuacana Creek, Upper Keechi Creek, Lower Keechi Creek, Boggy Creek, and Bedias Creek.

The Brazos River enters the four-district area at Milam and Robertson Counties, flowing southeast across the Bryan District and along the eastern edge of the Yoakum District (at Austin County), at which point it exits the study area. The floodplain along this stretch of the Brazos varies from 2 to $12 \mathrm{~km}$ in width (Proctor et al. 1970, 1979, 1981). Large, segmented, late Pleistocene terraces border the Holocene floodplain along its course. Dissected remnants of even higher gravelly Pleistocene terraces also are found sporadically along the upper slopes of the Brazos River valley. Three large tributaries enter the Brazos along this stretch of river. The Little River has a floodplain near its confluence with the Brazos of 5-6 km in width and is bordered by higher Pleistocene terraces. The Navasota River Holocene floodplain is $1-3 \mathrm{~km}$ wide and is also flanked by Pleistocene terraces. Yegua Creek has a Holocene floodplain that is ca. $3 \mathrm{~km}$ wide and is bordered intermittently by Pleistocene terraces. Holocene alluvium also is mapped for the tributary networks of these three drainages (Proctor et al. 1970, 1981). Other smaller tributaries of the Brazos River that display mapped Holocene alluvium include Pond, Walnut, Cedar, New Year, Caney, Jackson, and Mill Creeks.

The Colorado River enters the Yoakum District in Fayette County and flows southeast to Matagorda Bay and the Gulf of Mexico. The Holocene floodplain of the Colorado is up to $7.5 \mathrm{~km}$ wide, but at points near La Grange, upstream from Columbus, and downstream from Wharton, the floodplain becomes very narrow as the channel wedges between Pleistocene terraces and bedrock valley walls (Brown et al. 1987; Proctor et al. 1979). Tributaries of the Colorado that display mapped Holocene alluvium include Buckners, Cummins, and Skull Creeks.

The Guadalupe River is one of two larger river systems that are almost fully contained in the four-district area. The Guadalupe River heads in the northwestern portion of the San Antonio District and flows east and then southeast across the Yoakum District before it empties into San Antonio Bay. Near its headwaters, the Holocene floodplain of the Guadalupe is very narrow, and floodplain and terrace alluvium are not mapped separately (Barnes and Rose 1981; Brown et al. 1974). As the Guadalupe River enters the Balcones Canyonlands, its valley narrows, and the river becomes canyon confined. 


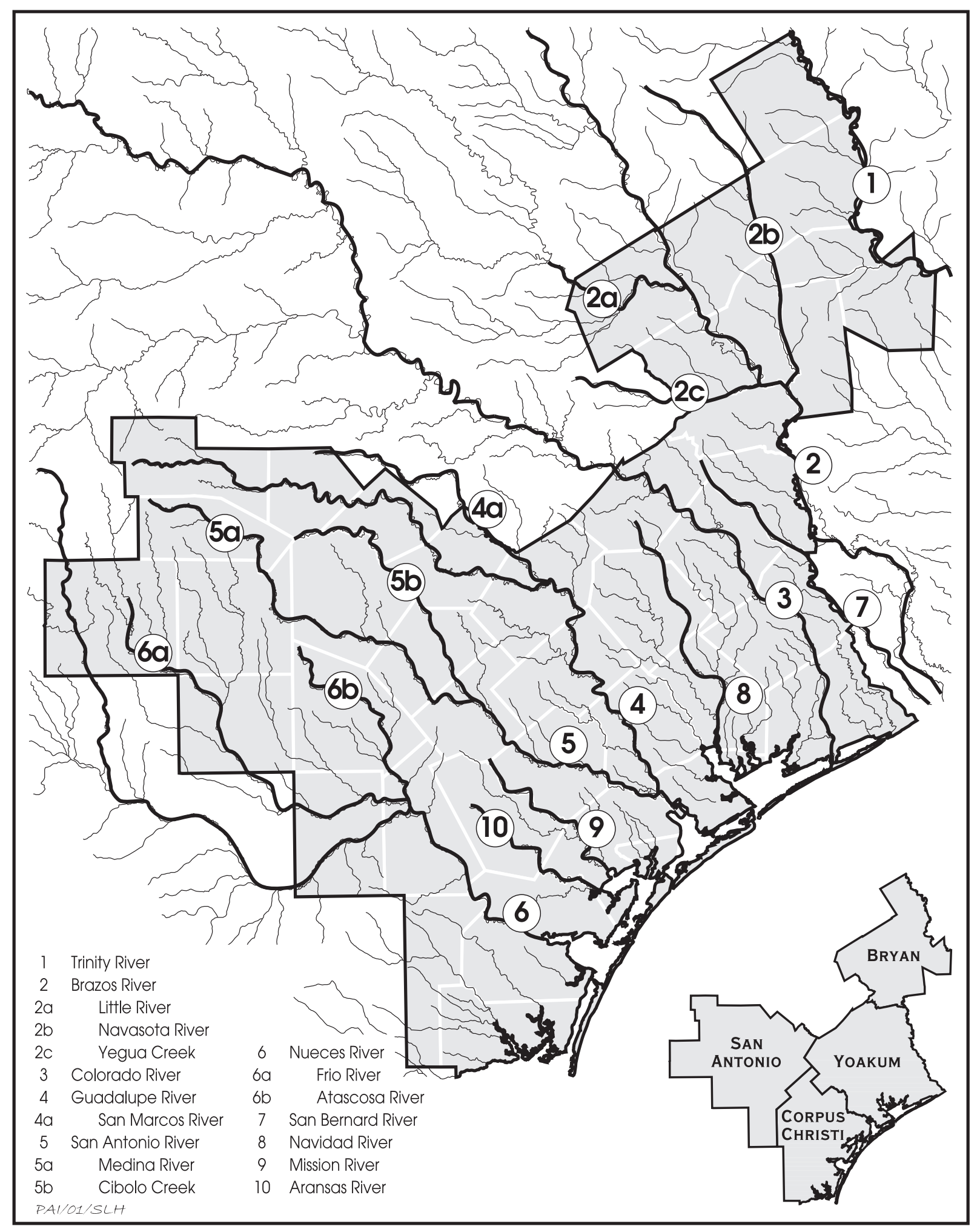

Figure 2. Major drainages in the Bryan, Corpus Christi, San Antonio, and Yoakum Districts. 
Floodplain and terraces are not individually mapped, or they are so small that they are not mapped at all (Brown et al. 1974). Crossing the Balcones Fault zone, the Guadalupe turns and flows southeast. As it exits the fault zone and enters the Gulf Coastal Plain, its valley and floodplain widen. On the Coastal Plain the upper reaches of the Guadalupe River floodplain are less than $0.5 \mathrm{~km}$ to $4.5 \mathrm{~km}$ wide and flanked sporadically by large Pleistocene terraces. Along its lower course, the floodplain is 1.0 to $7.5 \mathrm{~km}$ wide and bordered intermittently by Pleistocene terraces and terraces of the Deweyville formation (Brown et al. 1987). Throughout its headwaters and the Balcones Canyonlands, tributaries of the Guadalupe River are small. Tributaries Johnson Creek, Turtle Creek, and Verde Creek all have mapped Holocene and Pleistocene alluvium. On the Gulf Coastal Plain, the tributaries are much larger. The San Marcos River, Peach Creek, Sandies Creek, and Coleto Creek, as well as many of their tributaries, have wide Holocene floodplains that are flanked intermittently by Pleistocene terraces.

The San Antonio River is the second river system fully contained within the four-district area. Tributaries of the San Antonio River head in the northwestern portion of the San Antonio District and merge in and south of the city of San Antonio. Southeast of the city, the San Antonio River turns and flows southeast across the Corpus Christi District before it joins the Guadalupe River just northwest of San Antonio Bay.

Headwater tributaries of the San Antonio with mapped late Quaternary floodplains and terraces include the Medina River, Medio Creek, Leon Creek, Olmos Creek, Cibolo Creek, and Salado Creek. As these drainages come together (Brown et al. 1974), the valley and floodplain widen as the river flows across the Gulf Coastal Plain. Bordered by large Pleistocene terraces, the floodplain of the San Antonio River is up to $4 \mathrm{~km}$ wide. Larger tributaries of the San Antonio River on the Gulf Coastal Plain with mapped alluvium include Manahuilla Creek, Cabeza Creek, Hord Creek, Escondido Creek, and Ecleto Creek (Brown et al. 1987).

The Nueces River enters the San Antonio District in Uvalde County, flowing south and leaving the study area once it exits the county. Along its course through Uvalde County, the Nueces River valley is narrow, though the Holocene floodplain and late Quaternary terraces are mapped separately (Brown et al. 1974; Waechter et al. 1977). Tributaries along this portion of the Nueces course are small, though a few such as the West Nueces River and Indian Creek display mapped Holocene floodplains and Pleistocene terraces (Brown et al. 1974; Waechter et al. 1977). The Nueces River reenters the San Antonio District at McMullen County, flowing northeast and entering the Corpus Christi District at Live Oak County. Here, the river turns and flows southeast to Nueces and Corpus Christi Bays. Along this portion of its course, the Nueces floodplain is up to $4 \mathrm{~km}$ wide and is up to $6 \mathrm{~km}$ wide near its mouth. Pleistocene terraces flank the Holocene floodplain. Tributaries along this stretch of the Nueces River include two large rivers, the Frio and Atascosa, and many smaller creeks. The Frio and Atascosa Rivers and their network of tributaries display extensive Holocene floodplains up to $2.5 \mathrm{~km}$ wide and large Pleistocene terraces (Brown et al. 1976). The many smaller tributaries with mapped Holocene floodplains include Green Branch Creek, Piscachar Creek, Guadalupe Creek, Elm Creek, Spring Creek, Mule Creek, Cow Creek, Dragon Creek, Salt Branch, and Sulphur Creek.

The smaller coastal river systems-which include the San Bernard, Navidad, Mission, and Aransas Rivers-also display drainage networks with mapped alluvial surfaces. The San Bernard basin lies between the Brazos and Colorado Rivers. The San Bernard River heads in Austin and Colorado Counties in the Yoakum District and flows southeast along the northeast boundary of the district (Wharton-Fort Bend County line). It exits the district at the intersection of Wharton, Fort Bend, and Brazoria Counties. The Holocene floodplain of the San Bernard is very narrow, less than $0.5 \mathrm{~km}$ (Aronow et al. 1982; Proctor et al. 1979). Before it exits the district, the San Bernard enters the old Colorado River valley, which is now occupied by Caney Creek. The Holocene floodplain alluvium merges with that of Caney Creek and the Colorado River to form an extensive floodplain 11-14 km wide (Aronow et al. 1982).

The Navidad River lies between the Colorado and Guadalupe drainage basins. It heads in Fayette County in the Yoakum District and flows south-southeast to Lavaca Bay. Along its upper reaches, the Holocene floodplain of the Navidad is very narrow and not even mapped 
along some stretches, though large Pleistocene terraces flank the channel (Proctor et al. 1979). Along its lower course, the floodplain is ca. $1-3 \mathrm{~km}$ wide (Brown et al. 1987; Proctor et al. 1979). The Lavaca River, a larger tributary of the Navidad River, heads in Lavaca County in the Yoakum District and joins the Navidad River downstream in Jackson County. The Holocene floodplain is ca. $1.5 \mathrm{~km}$ wide and is bordered by Pleistocene terraces along its course (Brown et al. 1987; Proctor et al. 1979). Other tributaries of the Navidad River displaying mapped Holocene alluvium include East Navidad River, West Navidad River, Sandy Creek, West Sandy Creek, Mulberry Creek, and Big Rocky Creek.

The Mission and Aransas Rivers lie between the San Antonio and Nueces River basins. The Mission River heads in Bee and Goliad Counties in the Corpus Christi District and flows southeast to empty in Mission Bay. The Mission River and its network of tributaries (Blanco Creek, Mucorrera Creek, Indian Creek, and Medio Creek) display narrow Holocene floodplains along sections of their courses, as well as Pleistocene terraces (Brown et al. 1987). The Aransas River and its tributaries head in Bee County and flow southeast, emptying into the southern end of Copano Bay. Like the Mission River and its tributaries, the Aransas River and its tributaries (Aransas Creek, Poesta Creek, and Chiltipin Creek) have narrow Holocene floodplains along sections of their courses, as well as Pleistocene terraces (Brown et al. 1987).

\section{SYNOPSIS OF NATIVE AMERICAN CULTURE HISTORY}

\section{Central Coastal Plain}

Many people, institutions, and governmental agencies have undertaken archeological investigations on the central coastal plain of Texas. Among the more prominent of these are excavations by The University of Texas at Austin and the Works Progress Administration at the Johnson and Kent-Crane sites in the Copano Bay and Aransas Bay areas (Campbell 1947, 1952); Story's (1968) excavations at the Ingleside Cove and Anaqua sites in San Patricio and Jackson Counties; excavations at 41AU37 and 41AU38 along Allen's Creek in southern Austin County by The University of Texas at Austin (Hall 1981); excavations by the Univer- sity of Texas at San Antonio (UTSA) at the Hinojosa site situated approximately $60 \mathrm{~km}$ inland from Corpus Christi Bay (Black 1986); explorations by the Texas Historical Commission (Mallouf et al. 1973) in the projected area of Palmetto Bend Reservoir along the Lavaca and Navidad Rivers of Jackson County; UTSA survey and site testing in the area of Coleto Creek Reservoir in Victoria and Goliad Counties (Fox and Hester 1976; Fox et al. 1979); extensive survey and excavation efforts, primarily by UTSA, at Choke Canyon Reservoir in Live Oak and McMullen Counties (Hall et al. 1982, 1986); excavations by the Texas Department of Transportation (TxDOT) at the Loma Sandia site in Live Oak County and subsequent analysis by The University of Texas at Austin (Taylor and Highley 1995); Robert A. Ricklis's (1990, 1996) work at the Holmes and McKinzie sites, among others, in the Corpus Christi and Copano Bay area; testing and data recovery excavations at sites along the Victoria Barge Canal in Victoria and Calhoun Counties (Gadus et al. 1999; Weinstein 1992); and recent work by the Texas Historical Commission at La Salle's Fort St. Louis (Davis and Bruseth 2000), as well as work at other Spanish Colonial Mission-period sites (Calhoun 1999; Hindes et al. 1999; Ricklis 1999; Walter 1999). Summaries of the prehistory of the region based on these investigations, and more complete bibliographies concerning previous work, have been compiled by Black (1989a), Weinstein (1992), Hester (1995), Ricklis (1995), and Tomka et al. (1997).

The earliest occupation of the coastal plain occurred in the Paleoindian period ca. 11,000 to 8,000 years ago. The first half of this period is marked by the occurrence of Clovis and Folsom dart points, almost always in isolated contexts. For instance, a Clovis point was recovered from San Patricio County near the mouth of the Nueces River (Hester 1976), and a Folsom point was recovered on Oso Creek (Hester 1980:6). Excavated Paleoindian components on the coastal plain include the deep terrace sites of Buckner Ranch located in Bee County, the Berger Bluff site in Goliad County, and the Johnston-Heller and J-2 Ranch sites in Victoria County. The Buckner Ranch site produced late Pleistocene fauna and hearth-like clusters of burned rocks, as well as Folsom, Plainview, Scottsbluff, and Angostura points (Sellards 1940). Hester (1978:8-9), in a reevaluation of Sellards's 
data, concluded that the site "served as a campsite for a succession of Paleo-Indian groups" possibly spanning 3,000 years. Though this site is the only one of the excavated components to produce a Folsom point, in a more recent discussion Hester (1995:434) states "no Folsom camps or kill sites have been located."

Late Paleoindian points such as Plainview and Golondrina have been recovered from the Johnston-Heller site and the J-2 Ranch site (Birmingham and Hester 1976; Fox et al. 1979). Clear Fork tools also were recovered at the Johnston-Heller site. The Berger Bluff site, now inundated by Coleto Creek Reservoir, produced a deeply buried hearth dated to ca. 8,000 to 6,000 years ago. This site is of interest because its faunal assemblage includes small animals not thought to be characteristic of a Paleoindian big-game subsistence pattern (Brown 1996: 497-498; Weinstein 1992:60). Investigation of these components indicates the earliest Americans' long-lived, slowly changing adaptation to the near-coast.

Evidence of Paleoindian use of the coastal zone also comes from isolated finds in eroded or disturbed contexts. The erosion is in part the result of a dramatic sea level change associated with the end of the last glaciation. At that time, sea level was much lower than today, and the Gulf shoreline was appreciably farther south of its present position (Aten 1983:117, 146). As sea level began to rise, it likely inundated many Paleoindian sites. Both artifacts and fossil bones have been recovered from Texas beaches and are believed to be eroding from submerged, relict deltaic landforms that contain these ancient sites. One such area that has produced artifacts and fossil bones is 41MG4, the Sargent Beach site. The site produced one late Paleoindian Angostura point, as well as Archaic Pedernales and Kent points and fossil bones, including horse, bison, and mammoth teeth. Fossil bones and teeth of mastodon, mammoth, bison, horse, camel, deer, and turtle without associated artifacts have been recovered from several nearby disposal areas for dredged materials along the Gulf Intracoastal Waterway west of the San Bernard River (Black and Cox 1983) and to the south in alluvium of the ancestral Palo Blanco River of northern Kenedy County (Shum 1980).

Toward the end of the Paleoindian period, a disruption in large game populations may have precipitated a greater reliance on a broadbased subsistence strategy (Aten 1983:152157). This presumed but probably overstated change in subsistence strategy has been used to mark the beginning of the Archaic period. There also is evidence of climatic fluctuations and additional episodes of sea level rise within this period. These fluctuations have been used to divide the Archaic into early, middle, and late subperiods.

The Early Archaic spans the period from 8000 to 5000 B.P. when sea level was still well south of its present location (Aten 1983:117). As with Paleoindian sites, few Early Archaic sites are known, and it has been suggested that populations and site densities continued to be low on the entire coastal plain (Story 1985:37). Projectile points diagnostic of the period include Gower, Wells, Bell, Andice, Martindale, Uvalde, and related forms (Black 1989a:49; Weinstein 1992:57). Inland along the edge of the coastal plain, sites are associated with upland landforms and high terraces, though several components within deep alluvium are known from the Choke Canyon area of Live Oak County (Scott and Fox 1982). Examples of sites from the coastal bend include 41VT17 (Fox and Hester 1976), the McKenzie site (Ricklis 1988), and the Swan Lake site (Prewitt et al. 1987). Though the Early Archaic components at these sites are ephemeral, they demonstrate early use of the estuarine bay shore environment. During the late part of the Early Archaic, the number of coastal components increased, as did the intensity of the occupations. It appears that both shellfish and fish were exploited to the extent that these early components likely functioned as fishing camps (Ricklis 1988:101-102, 1995: 272-278).

The coastline reached its present position in the Middle Archaic, which lasted from 5000 to 3000 B.P., with the climate approaching modern conditions at the end of the period (Aten 1983:137, 316; Story 1990:244). It has been suggested that these changes may have enhanced coastal resources enough that populations and site densities increased (Story 1985:39, 1990:244). Toward the end of this period, extensive shell middens appeared, signaling that the bays and estuaries had developed to the extent that shellfish had become a ubiquitous resource. On the coast in Aransas and Nueces Counties, this intensive exploitation 
of estuarine resources was first given the appellation Aransas Focus (Campbell 1947, 1952). Distinctive shell tools such as Busycon whorl scrapers and columella gouges mark Aransas sites. Similar tools have been recovered from shell midden sites as far north along the coast as Lavaca Bay and the lower reach of Caney Creek in Matagorda County (Fritz 1975:129).

To tighten the chronological and spatial parameters for this archeological manifestation, the Aransas Complex was defined for the Late Archaic period based on work at the Kent-Crane site (Campbell 1958; Corbin 1974). The Middle Archaic manifestation has been labeled the Kent Phase (Weinstein 1992:61). Projectile points including Matamoros, Bulverde, and Palmillas mark the Kent Phase. Other Middle Archaic period projectile points with inland ties include Morhiss, Nolan, Travis, and Refugio (Black 1989a:49; Weinstein1992:61).

Inland, data from the Choke Canyon Reservoir sites suggest that open camps along stream courses on natural levees and low terraces marked the Middle Archaic period. Features such as formal hearths, earth ovens, and concentrations of burned rocks point to an emphasis on use of plant resources (Hall et al. 1986). Possible baking pit features with associated concentrations of burned rocks also have been identified at coastal shell midden sites. One such Middle Archaic shell midden, 41CL9 situated in Calhoun County along the upper Guadalupe River estuary, also produced faunal data indicating that terrestrial resources contributed significantly to the coastal resource base (Gadus et al. 1999:35-73). These data suggest that, in general, subsistence practices may not have differed greatly between coastal and inland sites.

The Late Archaic period, which dates from ca. 3000 to 1250 B.P., is marked by a continuation and intensification of Aransas adaptations on the coast. Some sites, such as Mustang Lake on San Antonio Bay and Ingleside Cove on Corpus Christi Bay, produce faunal data that suggest intensive fishing (Ricklis 1995:281-280). Inland, the presence of grinding implements and large deposits of burned rocks at the Choke Canyon sites suggest continued, intensive exploitation of plant resources (Hester 1995:441). Point types found on the coast include Ensor, Darl, and Fairland. Inland point types for this period include Frio, Marcos, Montell, Morhiss,
Castroville, and Ellis (Black 1989a:51; Weinstein 1992:57). Overall, this period saw a continued increase in populations and trend toward defined territories (Story 1985:44-45, 48).

One indication of population increase is the expansion of formal cemeteries. Cemeteries appeared in the Middle Archaic period and grew in size and number though the Late Archaic and into the Late Prehistoric period (Hall 1995a:56 57). An extensive Middle Archaic through Late Prehistoric period cemetery has been excavated at Allen's Creek (Hall 1981). The site, 41AU36, is located on the Brazos River approximately $115 \mathrm{~km}$ north of the coast in Austin County. Burials showed an increase in traumatic deaths, specifically during the Late Archaic period, that might be considered evidence of a boost in hostilities suggesting greater territorial competition (Hall 1981:284-285). Closer to the coast, the Blue Bayou cemetery (41VT94) and the Morhiss cemetery (41VT1) are situated on the lower reach of the Guadalupe River in Victoria County (Campbell 1976:81-85; Huebner 1988). The Morhiss cemetery has been dated to the Archaic period by diagnostic projectile points recovered from the associated habitation site. Because shell ornaments and many lithic materials were recovered from the habitation site, investigators have suggested that the inhabitants had both inland and coastal interactions (Hall 1995a:49-50). Similar interactions can be suggested from the inland formal cemetery at the Loma Sandia site in Live Oak County (Taylor and Highley 1995). But Hall (1995b:645646) points out that though the grave furnishings from Loma Sandia suggest interaction with nearby coastal cultures, the overriding connection appears to be with cultures of the Rio Grande Plain. These suggested differences in interaction provide data needed for understanding territorial affiliations across the coastal plain.

The Late Prehistoric period began variously along the Texas coastal plain at ca. 1700 to 1250 B.P. It was marked by the addition of pottery and the bow and arrow to an otherwise Archaic technological repertoire (Aten 1983:297-304; Corbin 1976:91; Weinstein 1992:57). Scallorn arrow points, one of the earliest forms found on the coast, have been recovered from burials at the Blue Bayou site dating to the early Late Prehistoric, ca. A.D. 430-990 
(Huebner 1988). Scallorn points and expanding-stem arrow point forms also were recovered from more-inland sites such as the Berger Bluff site located in Goliad County (Brown 1983) and sites in the Choke Canyon area of Live Oak County (Hall et al. 1986). In many cases, no ceramics were associated with these components, suggesting separate arrival or development of the two technologies. Similarities of these components to the early Late Prehistoric Austin phase components of central Texas have been acknowledged (Brown 1983: 80-81; Weinstein 1992:63).

Slightly later but before A.D. 1000, bonetempered ceramics and expanding-stem arrow points are known from the Choke Canyon sites (Black 1989a:52), and Scallorn points and sandy paste ceramics like ceramics from the upper Texas coast appeared on the central coast. Scallorn points and sandy paste ceramics were recovered from the Anaqua site and other sites located along the lower Lavaca and Navidad Rivers in Jackson County (Mallouf et al. 1973:136; Story 1968), as well as the Kent-Crane site in Aransas County (Cox and Smith 1988). Weinstein (1992:64) suggests that these components are recognizable cultural manifestations that preceded introduction of Rockport ceramics along the south and central coasts.

Rockport ceramics, a sandy paste ware decorated with asphalt designs and incising, occur most often with Perdiz and Fresno points. Other arrow point types occasionally found include Starr, Padre, Scallorn, Young, Cliffton, and McGloin (Corbin 1974:43). The occurrence of these artifact types along the coast-generally in Kleberg, Nueces, San Patricio, Aransas, and Refugio Counties-has been used to define the Rockport phase of the Late Prehistoric-Historic period (Campbell 1952, 1958; Story 1968; Suhm et al. 1954). The Rockport phase has been linked to the historically known Karankawa Indians because that group continued to produce the distinctive asphalt-decorated and asphaltcoated ceramics well into historic times.

Archeological studies of prehistoric and historic Karankawa adaptive strategies suggest that these people took advantage of both the coastal estuarine and adjoining prairie-riverine resources. Based on sites in the Corpus Christi Bay and Copano Bay area, Ricklis (1996:100-124) discerned a seasonal pattern in the occupation of coastal and nearby inland sites that may reflect this strategy. Two Late Prehistoric site types have been identified. One is a shoreline fishing camp that has extensive deposits of estuarine resource remains, and the other is an inland hunting camp with large quantities of terrestrial game such as deer and bison (Ricklis 1996:33). Seasonal data based on fish otoliths and Rangia cuneata samples indicate that the fishing camps were occupied in the fall through winter or early spring and that hunting camps were occupied in the spring and summer (Ricklis 1996:70-71, 89-95). In this model, fishing camps were occupied at a time of year when a reliable resource- that is, fishwas concentrated along the coast and allowed people to mass. Concomitantly, hunting camps represent population dispersal geared toward more-scattered resources-bison and deer. How far inland the Karankawa may have journeyed on their seasonal round and what interactions they may have had with inland-based groups are questions that require additional research.

Though the Karankawa may have moved inland seasonally to hunt bison and deer, faunal evidence from Hinojosa site in Jim Wells County and the Choke Canyon sites suggests that resident inland groups may have focused both on large game and on a wide range of smaller animals (Steele 1986; Steele and Hunter 1986). Recognition of a related lithic tool kit emphasized the importance of large game such as bison to the subsistence base (Black 1989a:53-54). Consisting of Perdiz arrow points, small end scrapers, and beveled knives, this tool kit has been linked to the Toyah phase cultures that appear to have originated on the Southern Plains and moved south to central Texas, probably in response to southwardexpanding bison herds (Black 1989a:57). The Toyah phase tool kit has been identified at the Hinojosa site and is often found within Rockport phase sites on the central coast (Black 1986:254-255; Ricklis 1995:285, 287). But the mechanisms behind adoption of this Toyah technology and its meaning for the coastal and nearcoastal peoples have yet to be clearly defined (see Johnson [1994] for a wide-ranging discussion of the Toyah culture).

Coastal aboriginal groups were affected not only by inland aboriginal groups, but they also bore the brunt of early contact with European explorers and colonists. The first encounter was 
that of the Spanish shipwreck survivor and eventual trader Alvar Nuñez Cabeza de Vaca, who lived and traveled with various aboriginal groups across coastal Texas ca. 1528 (Hester 1999:17-19). Reestablishing Cabeza de Vaca's movements places him on the Texas coast in the vicinity of San Antonio, Copano, and Corpus Christi Bays (Campbell and Campbell 1981:2-9). The Karankawa also met Robert Sieur de La Salle on his fateful expedition that ended along Matagorda Bay in the winter of 1685 (Ricklis 1996:1,112). Recent work at the site of La Salle's Fort St. Louis (41VT4) and the excavation of La Salle's ship, the Belle, in Matagorda Bay will provide new information on this contact and the lives of the Frenchmen who participated in that expedition (Davis and Bruseth 2000). The French presence on the Texas coast was short, but the Spanish, with their emphasis on establishing missions and presidios, had a lasting effect.

Spanish attempts to establish missions and presidios along the coastal plain continued through the 1700s. These included Mission Espiritu Santo, established in 1722 in the present vicinity of Jackson County and then moved to Victoria County in 1726, Presidio La Bahia and Mission Rosario established in 1749 and 1754 in Goliad County, and Mission Nuestra Señora de Refugio, first located in Calhoun County and then moved to Refugio County in 1795 (Ricklis 1996:145). Recent investigations of some of these sites, including the major ongoing studies of TxDOT at the Mission Refugio site, have provided information on the mobility patterns, economic activities, and interactions of both Spanish and Native American occupants (Calhoun 1999; Ricklis 1999; Walter 1999). These investigations, as well as work on Late Prehistoric and historic aboriginal sites, appear to indicate that coastal aboriginal groups kept their ethnic identities despite attempts by the Spanish to missionize them, and to some extent they fit the mission system into their aboriginal subsistence pattern (Ricklis 1996:159-168). Consequently, local coastal Native American groups, such as the Karankawa, survived as much-reduced but viable groups into the nineteenth century. Native groups did not, however, survive the aggressive Anglo-American settlement of the Texas coast that took place during the nineteenth and twentieth centuries.

\section{Southeast Margin of Central Texas}

The archeological record of the central Texas region is known from decades of investigations of stratified open air sites and rockshelters throughout the Edwards Plateau, its highly dissected eastern and southern margins, and the adjoining margins of physiographic regions to the east and south (see Collins [1995] for review). Traditionally, the central Texas archeological area has included the Balcones Canyonlands and Blackland Prairie - that is, the northern part of the San Antonio District (e.g., Prewitt 1981; Suhm 1960). These two areas are on the periphery of the central Texas archeological area, and their archeological records and projectile point style sequences contain elements that suggest influences from and varying degrees of contact over time with other areas such as the Lower Pecos and Gulf Coastal Plain (Collins 1995; Johnson and Goode 1994). Archeological sites in these two areas of the San Antonio District that have contributed important information include the Richard Beene site at Applewhite Reservoir (McGraw and Hindes 1987; Thoms et al. 1996; Thoms and Mandel 1992), the Cibolo Crossing site at Camp Bullis (Kibler and Scott 2000), the Panther Springs Creek site in Bexar County (Black and McGraw 1985), the Jonas Terrace site in Medina County (Johnson 1995), the Camp Pearl Wheat site in Kerr County (Collins et al. 1990), 41BX1 in Bexar County (Lukowski 1988), 41BX300 in Bexar County (Katz 1987), and several sites at Canyon Reservoir (Johnson et al. 1962). For more-complete bibliographies concerning archeological work done in the region, see Black (1989b), Collins (1995), and Johnson and Goode (1994).

Surficial and deeply buried sites, rockshelter sites, and isolated artifacts represent Paleoindian (11,500-8800 B.P.) occupations of the Central Texas region. The period is often described as having been characterized by small but highly mobile bands of foragers who were specialized hunters of Pleistocene megafauna. But Paleoindians probably used a much wider array of resources (Meltzer and Bever 1995:59), including small fauna and plant foods. Faunal remains from Kincaid Rockshelter and the Wilson-Leonard site (41WM235) support this view (Bousman 1998; Collins 1998; Collins et al. 1989). Longstanding ideas about Paleoindian 
technologies also are being challenged.

Collins (1995) divides the Paleoindian period into early and late subperiods. Two projectile point styles, Clovis and Folsom, are included in the early subperiod. Clovis chipped stone artifact assemblages, including the diagnostic fluted lanceolate Clovis point, were produced by bifacial, flake, and prismatic-blade techniques on high-quality and oftentimes exotic lithic materials (Collins 1990). Along with chipped stone artifacts, Clovis assemblages include engraved stones, bone and ivory points, stone bolas, and ochre (Collins 1995:381; Collins et al. 1992). Clovis points are found evenly distributed along the eastern edge of the Edwards Plateau, where the presence of springs and outcrops of chert-bearing limestone are common (Meltzer and Bever 1995:58). Sites within the area yielding Clovis points and Clovis-age materials include Kincaid Rockshelter (Collins et al. 1989), Pavo Real (Henderson and Goode 1991), and San Macros Springs (Takac 1991). A probable Clovis polyhedral blade core and blade fragment were found at the Greenbelt site in San Antonio (Houk et al. 1997). Analyses of Clovis artifacts and site types suggest that Clovis peoples were well-adapted, generalized hunter-gatherers with the technology to hunt larger game but not solely rely on it. In contrast, Folsom tool kits-consisting of fluted Folsom points, thin unfluted (Midland) points, large thin bifaces, and end scrapers-are more indicative of specialized hunting, particularly of bison (Collins 1995:382). Folsom points have been recovered from Kincaid Rockshelter (Collins et al. 1989) and Pavo Real (Henderson and Goode 1991).

Postdating Clovis and Folsom points in the archeological record are a series of dart point styles (primarily unfluted lanceolate darts) for which the temporal, technological, or cultural significance is unclear. Often, the Plainview type name is assigned these dart points, but Collins (1995:382) has noted that many of these points typed as Plainview do not parallel Plainview type-site points in thinness and flaking technology. Recent investigations at the WilsonLeonard site (see Bousman 1998) and a statistical analysis of a large sample of unfluted lanceolate points by Kerr and Dial (1998) have shed some light on this issue. At WilsonLeonard, the Paleoindian projectile point sequence includes an expanding-stem dart point termed Wilson, which dates to ca. 10,0009500 B.P. Postdating the Wilson component is a series of unfluted lanceolate points referred to as Golondrina-Barber, St. Mary's Hall, and Angostura, but their chronological sequence is poorly understood. Nonetheless, it has become clear that the artifact and feature assemblages of the later Paleoindian subperiod appear to be Archaic-like in nature and in many ways may represent a transition between the early Paleoindian and succeeding Archaic periods (Collins 1995:382).

The Archaic period for central Texas dates from ca. 8800 to $1300-1200$ B.P. (Collins 1995) and generally is believed to represent a shift toward hunting and gathering of a wider array of animal and plant resources and a decrease in group mobility (Willey and Phillips 1958:107108). In the eastern and southwestern United States and on the Great Plains, development of horticultural-based, semisedentary to sedentary societies succeeds the Archaic period. In these areas, the Archaic truly represents a developmental stage of adaptation as Willey and Phillips (1958) define it. For central Texas, this notion of the Archaic is somewhat problematic. An increasing amount of evidence suggests that Archaic-like adaptations were in place before the Archaic (see Collins 1995:381-382, 1998; Collins et al. 1989) and that these practices continued into the succeeding Late Prehistoric period (Collins 1995:385; Prewitt 1981:74). In a real sense, the Archaic period of Central Texas is not a developmental stage, but an arbitrary chronological construct and projectile point style sequence. Establishment of this sequence is based on several decades of archeological investigations at stratified Archaic sites along the eastern and southern margins of the Edwards Plateau. Collins (1995) and Johnson and Goode (1994) have divided this sequence into three parts-early, middle, and late-based on perceived (though not fully agreed upon by all scholars) technological, environmental, and adaptive changes.

Early Archaic (8800-6000 B.P.) sites are small, and their tool assemblages are diverse (Weir 1976:115-122), suggesting that populations were highly mobile and densities low (Prewitt 1985:217). It has been noted that Early Archaic sites are concentrated along the eastern and southern margins of the Edwards Plateau (Johnson and Goode 1994; McKinney 
1981). This distribution may indicate climatic conditions at the time, given that these environments have more reliable water sources and a more diverse resource base than other parts of the region. Early Archaic projectile point styles include Hoxie, Gower, Wells, Martindale, and Uvalde. Clear Fork and Guadalupe bifaces and a variety of other bifacial and unifacial tools are common to Early Archaic assemblages. Construction and use of rock hearths and ovens, which had been limited during late Paleoindian times, became commonplace. The use of rock features suggests that retaining heat and releasing it slowly over an extended period were important in food processing and cooking and reflects a specialized subsistence strategy. Such a practice probably was related to cooking plant foods, particularly roots and bulbs, many of which must be subjected to prolonged periods of cooking to render them consumable and digestible (Black et al. 1997:257; Wandsnider 1997; Wilson 1930). Botanical remains, as well as other organic materials, are often poorly preserved in Early Archaic sites, so the range of plant foods exploited and their level of importance in the overall subsistence strategy are poorly understood. But recovery of charred wild hyacinth (Camassia scilloides) bulbs from an Early Archaic feature at the Wilson-Leonard site provides some insights into the types of plant foods used and their importance in the Early Archaic diet (Collins et al. 1998). Significant Early Archaic sites include the Richard Beene site in Bexar County (Thoms and Mandel 1992), the Camp Pearl Wheat site in Kerr County (Collins et al. 1990), and the Jetta Court site in Travis County (Wesolowsky et al. 1976).

During the Middle Archaic period (60004000 B.P.), the number and distribution of sites, as well as their size, probably increased as population densities grew (Prewitt 1981:73; Weir 1976:124, 135). Macrobands may have formed at least seasonally, or more small groups may have used the same sites for longer periods (Weir 1976:130-131). Development of burned rock middens toward the end of the Middle Archaic suggest a greater reliance on plant foods, although tool kits still imply a considerable dependence on hunting (Prewitt 1985:222-226). Middle Archaic projectile point styles include Bell, Andice, Taylor, Baird, Nolan, and Travis. Bell and Andice points reflect a shift in lithic technology from the preceding Early Archaic
Martindale and Uvalde point styles (Collins 1995:384). Johnson and Goode (1994:25) suggest that the Bell and Andice darts are parts of a specialized bison-hunting tool kit. They also believe that an influx of bison and bison-hunting groups from the Eastern Woodland margins during a slightly more mesic period marked the beginning of the Middle Archaic. Though no bison remains were recovered or present, Bell and Andice points and associated radiocarbon ages were recovered from the Cibolo Crossing (Kibler and Scott 2000), Panther Springs Creek, and Granberg II (Black and McGraw 1985) sites in Bexar County. Bison disappeared as more-xeric conditions returned during the late part of the Middle Archaic. Later Middle Archaic projectile point styles represent another shift in lithic technology (Collins 1995:384; Johnson and Goode 1994:27). Prewitt (personal communication 2000) postulates that the production and morphology of Travis and Nolan points are similar to projectile points from the Lower Pecos region. Because they appeared earlier in the Lower Pecos than in central Texas, such characteristics as beveled stems and overall morphology may have originated in the Lower Pecos. At the same time, a shift to more-xeric conditions saw the burned rock middens develop, probably because intensified use of a specific resource (geophytic or xerophytic plants) or resource patches meant the debris of multiple rock ovens and hearths accumulated as middens on stable to slowly aggrading surfaces, as Kelley and Campbell (1942) suggested many years ago. Johnson and Goode (1994:26) believe that the dry conditions promoted the spread of yuccas and sotols, and that it was these plants that Middle Archaic peoples collected and cooked in large rock ovens.

During the succeeding Late Archaic period (4000 to 1300-1200 B.P.), populations continued to increase (Prewitt 1985:217). Within stratified Archaic sites such as Loeve-Fox, Cibolo Crossing, and Panther Springs Creek, the Late Archaic components contain the densest concentrations of cultural materials. Establishment of large cemeteries along drainages suggests certain groups had strong territorial ties (Story 1985:40). A variety of projectile point styles appeared throughout the Late Archaic period. Johnson and Goode (1994:29-35) divide the Late Archaic into two parts, Late Archaic I and II, based on increased population densities and 
perceived evidence of Eastern Woodland ceremonial rituals and religious ideological influences. Middle Archaic subsistence technology, including the use of rock and earth ovens, continued into the Late Archaic period. Collins (1995:384) states that, at the beginning of the Late Archaic period, the use of rock ovens and the resultant formation of burned rock middens reached its zenith and that the use of rock and earth ovens declined during the latter half of the Late Archaic. There is, however, mounting chronological data that midden formation culminated much later and that this high level of rock and earth oven use continued into the early Late Prehistoric period (Black et al. 1997:270284; Kleinbach et al. 1995:795). A picture of prevalent burned rock midden development in the eastern part of the central Texas region after 2000 B.P. is gradually becoming clear. This scenario parallels the widely recognized occurrence of post- 2000 B.P. middens in the western reaches of the Edwards Plateau (see Goode 1991).

The use of rock and earth ovens (and the formation of burned rock middens) for processing and cooking plant foods suggests that this technology was part of a generalized foraging strategy. The amount of energy involved in collecting plants, constructing hot rock cooking appliances, and gathering fuel ranks most plant foods relatively low based on the resulting caloric return (Dering 1999). This suggests that plant foods were part of a broad-based diet (Kibler and Scott 2000:134) or part of a generalized foraging strategy, an idea Prewitt (1981) put forth earlier. At times during the Late Archaic, this generalized foraging strategy appears to have been marked by shifts to a specialized economy focused on bison hunting (Kibler and Scott 2000:125-137). Castroville, Montell, and Marcos dart points are elements of tool kits often associated with bison hunting (Collins 1968). Archeological evidence of this association is seen at Bonfire Shelter in Val Verde County (Dibble and Lorrain 1968), Jonas Terrace (Johnson 1995), Oblate Rockshelter (Johnson et al 1962:116), John Ischy (Sorrow 1969), and Panther Springs Creek (Black and McGraw 1985).

The Archaic period represents a hunting and gathering way of life that was successful and that remained virtually unchanged for more than 7,500 years. This notion is based in part on fairly consistent artifact and tool assemblages through time and place and on resource patches that were used continually for several millennia, as the formation of burned rock middens shows. This pattern of generalized foraging, though marked by brief shifts to a heavy reliance on bison, continued almost unchanged into the succeeding Late Prehistoric period.

Introduction of the bow and arrow and, later, ceramics into Central Texas marked the Late Prehistoric period. Population densities dropped considerably from their Late Archaic peak (Prewitt 1985:217). Subsistence strategies did not differ greatly from the preceding period, although bison again became an important economic resource during the late part of the Late Prehistoric period (Prewitt 1981:74). Use of rock and earth ovens for plant food processing and the subsequent development of burned rock middens continued throughout the Late Prehistoric period (Black et al. 1997; Kleinbach et al. 1995:795). Horticulture came into play very late in the region but was of minor importance to overall subsistence strategies (Collins 1995:385).

In central Texas, the Late Prehistoric period generally is associated with the Austin and Toyah phases (Jelks 1962; Prewitt 1981:82-84). Austin and Toyah phase horizon markers, Scallorn-Edwards and Perdiz arrow points, respectively, are distributed across most of the state. Violence and conflict often marked introduction of Scallorn and Edwards arrow points into central Texas-many excavated burials contain these point tips in contexts indicating they were the cause of death (Prewitt 1981:83). Subsistence strategies and technologies (other than arrow points) did not change much from the preceding Late Archaic period. Prewitt's (1981) use of the term "Neoarchaic" recognizes this continuity. In fact, Johnson and Goode (1994:39-40) and Collins (1995:385) state that the break between the Austin and Toyah phases could easily and appropriately represent the break between the Late Archaic and the Late Prehistoric.

Around 1000-750 B.P., slightly more-xeric or drought-prone climatic conditions returned to the region, and bison came back in large numbers (Huebner 1991; Toomey et al. 1993). Using this vast resource, Toyah peoples were equipped with Perdiz point-tipped arrows, end scrapers, fourbeveled-edge knives, and plain bone-tempered 
ceramics. Toyah technology and subsistence strategies represent a completely different tradition from the preceding Austin phase. Collins (1995:388) states that formation of burned rock middens ceased as bison hunting and group mobility obtained a level of importance not witnessed since Folsom times. Although the importance of bison hunting and high group mobility hardly can be disputed, the argument that burned rock midden development ceased during the Toyah phase is tenuous. A recent examination of Toyah-age radiocarbon assays and assemblages by Black et al. (1997) suggests that their association with burned rock middens represents more than a "thin veneer" capping Archaic-age features. Black et al. (1997) claim that burned rock midden formation, although not as prevalent as in earlier periods, was part of the adaptive strategies of Toyah peoples.

Hester (1989) and Newcomb (1961) provide historical accounts of Native Americans and their interactions with the Spanish, the Republic of Mexico, the Texas Republic, and the United States throughout the region. The beginning of the late seventeenth and early eighteenth centuries was an era of more-permanent contact between Europeans and Native Americans as the Spanish moved northward out of Mexico to establish settlements and missions on their northern frontier (see Castañeda [1936-1958] and Bolton [1970] for extended discussions of the mission system and Indian relations in Texas and the San Antonio area). There is little available information on aboriginal groups and their ways of life except for the fragmentary data Spanish missionaries gathered. In the San Antonio area and areas to the south, these groups have been referred to collectively as Coahuiltecans because of an assumed similarity in way of life, but many individual groups may have existed (Campbell 1988). Particular Coahuiltecan groups, such as the Payaya and Juanca, have been identified as occupying the San Antonio area (Campbell 1988). This area also served as a point of contact between the southward-advancing Apaches and the Spanish, with native groups often caught in between. Disease and hostile encounters with Europeans and intruding groups such as the Apache were already wreaking their inevitable and disastrous havoc on native social structures and economic systems by this time.
Establishment of the mission system in the first half of the eighteenth century to its ultimate demise around 1800 brought the peaceful movement of some indigenous groups into mission life, but others were forced in or moved in to escape the increasing hostilities of southward-moving Apaches and Comanches. Many of the Payaya and Juanca lived at Mission San Antonio de Valero (the Alamo), but so many died there that their numbers declined rapidly (Campbell 1988:106, 121-123). By the end of the mission period, European expansion and disease and intrusions by other Native American peoples had decimated many Native American groups. The small numbers of surviving Payaya and Juanca were acculturated into mission life. The last references to the Juanca and Payaya were recorded in 1754 and 1789, respectively, in the waning days of the mission (Campbell 1988:98, 123). By that time, intrusive groups such as the Tonkawa, Apache, and Comanche had moved into the region to fill the void. Outside of the missions, few sites attributable to these groups have been investigated. To complicate matters, many aboriginal ways of life endured even after contact with the Spanish. For example, manufacture of stone tools continued even for many groups settling in the missions (Fox 1979). The nineteenth century brought the final decimation of the Native American groups and the U.S. defeat of the Apaches and Comanches and their removal to reservations.

\section{Southern East-Central Texas}

This synopsis focuses on the southern part of east-central Texas-the Bryan District and the northern part of the Yoakum District. Most of this area is within the Oak Woods and Prairies region, although Blackland Prairie occurs along the western and southern edges and in a narrow band through the middle. The archeology of parts of this area is reasonably well understood because several large-scale projects involving excavations have been undertaken. Among those projects that have contributed important information are Richland-Chambers Reservoir in Freestone and Navarro Counties (Bruseth and Martin 1987; McGregor and Bruseth 1987); Lake Limestone in Leon, Limestone, and Robertson Counties (Mallouf 1979); Jewett Mine in Freestone and Leon Counties 
(Espey, Huston and Associates, Inc. 1984; Fields 1987, 1990; Fields and Klement 1995; Fields et al. 1991; Gadus et al. 2001); Calvert Mine in Robertson County (Davis et al. 1987; Robinson and Turpin 1993); Sandow Mine in Lee and Milam Counties (Rogers 1997; Rogers and Kotter 1995; Rogers 1999); Gibbons Creek Mine in Grimes County (Rogers 1993, 1994, 1995); Somerville Lake in Burleson, Lee, and Washington Counties (Peterson 1965; Thoms and Ahr 1996); Cummins Creek Mine in Fayette County (Kotter et al. 1991); Fayette Power Plant in Fayette County (Skelton 1977); 41BU16 in Burleson County, the Kennedy Bluffs and Bull Pen sites in Bastrop County, and the Black Hopper site in Fayette County excavated because of Texas Department of Transportation projects (Bement 1989; Ensor and Mueller-Wille 1988; Fullem 1977; Roemer and Carlson 1987); and miscellaneous excavations such as those at the Winnie's Mound and Frisch Auf! sites (Bowman 1985; Hester and Collins 1969). Not surprisingly given its location, the archeology of this region often has been seen as reflecting influences from adjoining regions with better-defined cultural histories, with the strength of these influences varying across the area. For example, Caddoan influences predominate in the northern part of the study area, coastal influences are especially strong on the southeastern edge, and similarities to central Texas are most pronounced on the southern and western margins.

As elsewhere in Texas, excavated and reported Paleoindian materials from southern east-central Texas are scarce, but a variety of early points have been found, largely in mixed or surface contexts, and it is clear that this part of Texas was used throughout the period from ca. 10,000 to 6500 B.C. Presumably, this use was by hunter-gatherer groups with low population densities and high residential mobility. One significant early find, estimated to date between 12,000 and 10,000 B.P., was at the DuewellNewberry site in Brazos County (Carlson et al. 1984). The find consisted of mammoth remains deeply buried in Brazos River alluvium. Although no artifacts were found in association, some of the bones contained cut marks indicating human modification. Other early materials from the region include a few San Patrice points from Richland-Chambers Reservoir (McGregor and Bruseth 1987:176-179); one Folsom point from Lake Limestone (Mallouf 1979:44); a
Golondrina point, several untyped lanceolate points, and a radiocarbon assay of 8940 B.P. from the Lambs Creek knoll site at the Jewett Mine (Fields 1995:304), as well as a Clovis point, a Meserve-Dalton point, and two San Patrice points from two other sites (Day 1984:83; Fields et al. 1991:317); a San Patrice point and a Plainview-like point from the lowermost stratum at the Winnie's Mound site (Bowman 1985:44); a Plainview point and a Golondrina point from the Chesser site at the Sandow Mine (Rogers and Kotter 1995:134); occasional Dalton and San Patrice points from sites at the Gibbons Creek Mine (Rogers 1995:166); a Dalton point from Somerville Lake (Thoms and Ahr 1996:13); and a few Plainview and Meserve points from sites in the Fayette Power Plant Project area (Skelton 1977:124).

Many of the excavated sites in the region have components dating to the Archaic period (ca. 8500-1250 B.P.), and it is clear that the area supported sizeable populations by the last third of the period. Materials dating to the early and middle parts of the period are widespread but not very abundant. For example, the relatively intensive work at Richland-Chambers Reservoir and Lake Limestone and Jewett Mine at the north end of the study area suggests limited use of the western edge of the Oak Woodlands before the Late Archaic, although for both areas it has been noted that data pertaining to the early to middle parts of the Archaic may be scarce in part because sites dating to this interval lie deeply buried or were removed by extensive erosion during the mid-Holocene (Fields 1995:302; McGregor and Bruseth 1987:229). Only a few radiocarbon assays predating 4000 B.P. were obtained from these project areas, and only one excavated site, Charles Cox at the Jewett Mine, contains a substantial component that might be Early or Middle Archaic in age (Fields 1995:303-305). A variety of untyped dart points with expanding and parallel stems appear to represent this component, but later materials are mixed in as well, and the deposits were not dated by radiocarbon. Points dated to this interval in central Texas-for example, Bell, Andice, Calf Creek, and Hoxie-occur at both Richland-Chambers Reservoir and the Jewett Mine, but only in very small numbers.

Similar conclusions can be reached for the other project areas listed above. The work at the Calvert Mine has not revealed evidence of 
significant Early to Middle Archaic occupations, and the evidence from the Sandow Mine is limited as well-an early split-stem point, an Angostura-Hoxie point, and two Travis points from the Chesser site and a Martindale point from 41LE120 (Rogers 1997:52; Rogers and Kotter 1995:134). Early to Middle Archaic materials elsewhere in the region, all from sites that date predominantly later, include a Hoxie point from 41GM166 at the Gibbons Creek Mine (Rogers 1995:166-167); an Angostura-like point from Somerville Lake (Thoms and Ahr 1996:13); a few Travis, Nolan, Hoxie, and Uvalde points from the Cummins Creek Mine (Kotter et al. 1991:111, 124, 136); single Gower and Angostura points from the Fayette Power Plant (Skelton 1977:124, 125); and a Travis point from the Black Hopper site (Fullem 1977:11).

Two excavated sites with substantial Early to Middle Archaic components are Winnie's Mound and Kennedy Bluffs, although the primary components at both of these sites are Late Archaic. At the former, a Bell point, a Hoxie point, five Gower-Uvalde-like points, two Gowerlike points, and five Hoxie-Gower-Uvalde-like points were found in the lower strata, along with at least one hearth (Bowman 1985:43-47, 70). At Kennedy Bluffs, only a few Early to Middle Archaic points (one Travis, one Tortugas-Taylor, two Angostura, one Gower-like, and one Nolan) were found in the area TxDOT excavated, but many items dating to this interval were documented among the materials collectors recovered from another part of the site (Bement et al. 1989:35-36, 71-154). Given the limited information available for this part of the period, it is difficult to say much about adaptations and life. It does appear, however, that the region was used in a limited fashion, presumably reflecting low population densities among mobile hunter-gatherers.

The late part of the Archaic period-after about 4000 B.P.- presents a very different picture. All parts of the area that have been studied archeologically contain sites dating to this period, and the Late Archaic represents the earliest time for which much is known about Native American life. One of the more-complete pictures of the archeology of the Late Archaic for this region comes from the Oak Woodlands at the eastern margin of the Blackland Prairie on the north edge of the study area. Along Richland and Chambers Creeks, Late Archaic groups appear to have been hunter-gatherers whose subsistence pursuits focused on wild plant foods such as hickory nuts and prairie turnip and faunal taxa such as deer, turtles, small mammals, birds, and fish (McGregor and Bruseth 1987:236-240). Although presumably not sedentary, these groups clearly used the area intensively for residential purposes, and populations appear to have increased while territory sizes decreased. A conspicuous component of the record is the so-called Wylie pit, examples of which were excavated at the Bird Point Island and Adams Ranch sites. These were large features that appear to have been used for communal processing of vegetal resources (and later as cemeteries), perhaps in the context of band aggregation in tension zones as territories decreased in size (McGregor and Bruseth 1987:237).

The Navasota River valley and the area eastward to and across the Trinity River divide also were occupied with increased intensity during the Late Archaic period (Fields 1995:307-309), although there is no evidence for the kind of population aggregations indicated at Richland-Chambers Reservoir. Faunal and macrobotanical remains were not preserved in the Late Archaic components at Lake Limestone and the Jewett Mine, except for the ubiquitous hickory nut shells, and thus data on subsistence are limited. Nonetheless, it is surmised that these hunter-gatherers subsisted on a variety of wild plant foods and game, especially deer. Of the 20 excavated components assigned to this period, 15 are interpreted as residential bases and 5 as procurement or processing locations. Five of the residential-base components are situated along the Navasota River and appear to represent general-purpose campsites, and the others are in the uplands to the east and consist of 2 general-purpose residential bases and 8 residential bases at which activities focused heavily on plant processing and secondarily on hunting. This distinction suggests that Late Archaic settlement systems were based on the occurrence of plant foods. The analysis units interpreted as procurement-processing locations appear to have focused primarily on plant processing and then on hunting-related activities. Four of these are along streams in the uplands, and the fifth is along a Navasota River tributary to the west. The data from these 20 components are 
consistent with the idea that Late Archaic groups were chiefly foragers because procurement-processing locations suggesting logistical use are not frequent. Settlement systems appear to have been highly scheduled, probably by season, with residential sites in riverine settings differing from those in the uplands. Comparisons with earlier components at Lake Limestone and the Jewett Mine are difficult, but the much greater frequency of Late Archaic components and the overall greater intensity of use suggest increased population densities, decreased territories, or both. The occurrence of the Late Archaic cemetery at the Cottonwood Springs site along Lambs Creek on the east side of the Navasota River valley also points to this shift (Fields and Klement 1995).

Not only do constellations of projectile point styles (e.g., Dawson, Gary, Godley, Kent, Neches River oletha, and Yarbrough) from the RichlandChambers, Lake Limestone, and Jewett Mine areas indicate ties to the north and east rather than to the south and west, but each of these areas also has yielded information suggesting that ceramics may have been introduced into the material culture of local groups during the latest part of the Late Archaic, as they were across most of Texas to the east (where this interval usually is called the Early Ceramic period and sometimes the Woodland period).

At Richland-Chambers Reservoir, distinctive shell-tempered sherds were recovered from contexts dated between A.D. 200 and 700 at the Adams Ranch site (McGregor and Bruseth 1987:180-181), apparently representing the earliest ceramic industry in this part of the Trinity River basin. At Lake Limestone and the Jewett Mine, a few shell-tempered sherds, a few sherds with a fine kaolin paste but no obvious temper, and larger numbers of sandy paste ceramics and grog- or bone-tempered ceramics were found in contexts that appeared to predate arrow points (i.e., the latter part of the Late Archaic). Although some of these could be genuinely early, especially the sandy paste wares that are so reminiscent of the early ceramics that predominate in east Texas south of the Sabine River, it is possible that the other sherds intruded from later deposits (Fields 1995:308). In either case, sherds were sufficiently infrequent to suggest that, although ceramic containers may have been a notable addition to the material culture, they were not abundant.
The Late Archaic archeology of the other project areas in southern east-central Texas has not been deciphered to the same extent as that at Richland-Chambers Reservoir and the Jewett Mine, but it is clear that similar, though not identical, cultural developments occurred within hunter-gatherer groups across the region. The single excavated site at the Calvert Mine, 41RT267, apparently contains a Late Archaic component, but small sample sizes and the lack of features hamper interpretation (Robinson and Turpin 1993). Both of the excavated sites at the Sandow Mine-the Chesser site and the Walleye Creek site-have strong Late Archaic components. At these sites, many burned rock features were found in association with dart point types such as Bulverde, Pedernales, Lange, Marshall, Marcos, Ensor, Darl, and Fairland (Rogers 1999:96; Rogers and Kotter 1995:134). Although these types show distinct ties to Central Texas in general, Rogers (1999:96-97) argues that the last three represent more-local types especially common to the eastern margin of the Edwards Plateau. A single sandy paste sherd was recovered from the Chesser site, but it is unclear if it relates to terminal Archaic or Late Prehistoric use of the site. In either case, ceramics were a less-prominent part of the material culture here than they were farther to the east and north. The limited faunal and macrobotanical remains recovered suggest reliance on Carya nuts and deer (Rogers 1999:28, 31-32; Rogers and Kotter 1995:42-45, C-1-10).

To the east, two sites along the Brazos River, Winnie's Mound and 41BU16, have significant Late Archaic components (Bowman 1985; Roemer and Carlson 1987). Perhaps most important, both apparently contained cemeteries probably Late Archaic in age. Cemeteries here and elsewhere across the region perhaps represent increased population densities and definition of territories. The projectile point styles recovered-Bulverde, Darl, Dawson, Edgewood, Ensor, Fairland, Frio, Gary, Kent, Lange, Marcos, Pedernales, and Yarbrough-are a mix of types characteristic of central and eastern Texas. Winnie's Mound yielded a few sandy paste sherds, and 41BU16, a larger ceramic collection that is hard to relate typologically to ceramics in surrounding regions.

At the Gibbons Creek Mine on the east edge of the study area, most of the excavated sites 
have Late Archaic components, and Rogers (1995:167) suggests that this reflects "a less mobile population relying more heavily on the area's plant resources, particularly hickory nuts." Rock hearths are common at these sites, but other kinds of features are not. Not surprisingly, the most common dart point types-Gary, Kent, and Palmillas-show strong connections to the eastern part of the state rather than to central Texas (Rogers 1995:167). As at the Jewett Mine and Richland-Chambers Reservoir to the north, ceramics may have been added to the material culture during the latest Archaic. These early ceramics were sandy paste wares comparable to early ceramics elsewhere in southeastern Texas (Rogers 1995:167).

At Somerville Lake on Yegua Creek, the single site excavated, Erwin's Bridge, contained a strong Late Archaic component, although it was difficult to isolate it from the Late Prehistoric component (Peterson 1965). Most of the kinds of projectile points recovered-Bulverde, Castroville, Darl-like, Elam, Fairland, Palmillas, and Pedernales-resemble those from the Sandow Mine not far to the northwest, with both collections indicating ties to central Texas to the west. Erwin's Bridge yielded a small collection of ceramics, primarily sandy paste, but it is impossible to tell if these relate to the late Archaic or Late Prehistoric occupations.

Moving farther south into the Colorado River basin, the Kennedy Bluffs and Bull Pen sites in Bastrop County and most of the tested sites at the Fayette Power Plant and the Cummins Creek Mine have Late Archaic components. Both the Kennedy Bluffs site and the Bull Pen site contained evidence of extensive use of burned rock features associated with point styles typical of central Texas to the west, especially Pedernales, with Bulverde, Marcos, Montell, and Marshall-like points also at Kennedy Bluffs and Ensor, Fairland, and Darl at Bull Pen (Bement et al. 1989:21-30, 37-44; Ensor and Mueller-Wille 1988:181-183). These sites have been interpreted as seasonal base camps used repeatedly by hunter-gatherers for a variety of maintenance, extractive, and processing tasks (Ensor and Mueller-Wille 1988:183-200). At the Fayette Power Plant, a number of sites yielded similar styles of pointsPedernales, Marshall, Ensor, Darl, and Fairland. The last three types were especially common and indicated "a marked increase in site utili- zation and exploitation of the local resources" during terminal Archaic times (Skelton 1977:125-126). Several of the tested sites at the Cummins Creek Mine contained Darl, Ensor, Pedernales, and Mahomet points and were interpreted as having been used as short-term campsites during the Late Archaic period (Kotter et al. 1991:118-119, 159-160, 177).

Sites dating to the Late Prehistoric, after ca. A.D. 700, also are common across most of the region. As for the preceding period, good data on how Native Americans used the region comes from Richland-Chambers Reservoir and Lake Limestone and nearby Jewett Mine. Sites dating to this interval are frequent at RichlandChambers Reservoir, especially for the early half of the period, and it appears that there was a significant decline in population densities after about A.D. 1300 (McGregor and Bruseth 1987:245). The data suggest that most of the excavated sites with Late Prehistoric components were used for residential purposes (McGregor and Bruseth 1987:241, 244, 246), although there are some sites, for example the streamside concentrations of mussel shells and artifacts at $41 \mathrm{FT} 193$ and $41 \mathrm{NV} 139$, that probably had more-limited use. The house patterns at the Bird Point Island site point to intensive use by sedentary hunter-gatherers during the first half of the period, and other components that are contemporaneous, slightly earlier, or later (for example, at Bird Point Island, Adams Ranch, Irvine, and Little Cedar Creek) have middens and many features suggesting intensive use but no houses. These components may represent occupations that were seasonal in length. Macrobotanical remains point to use primarily of wild plant foods-hardwood nuts, a variety of seeds, tubers, and rhizomes (McGregor and Bruseth 1987:243). The only tropical cultigen is maize, and it occurs in very small quantities only in contexts dating to the last half of the period, so groups who lived in this area were predominantly hunters and gatherers. Alba, Scallorn, and Steiner arrow points were used during the early part of the period, and Perdiz and Cliffton points are more characteristic of the late part. Gary dart points may have been used through the early Late Prehistoric (McGregor and Bruseth 1987:183). Ceramics are moderately common and clearly relate to Caddoan wares, with most of the identified types (for example, Maydelle Incised, Poyner 
Engraved, and Weches Fingernail Impressed) indicating contact with groups in the Neches River drainage, east of the Trinity.

Work at Lake Limestone along the Navasota River and the Jewett Mine in the uplands to the east identified 12 components dating predominantly to the Late Prehistoric period, although not all are well dated (Fields 1995:313-317; Gadus et al. 2001). Six are interpreted as residential bases, and the other 6 are procurement-processing locations. These sites suggest that the Late Prehistoric period saw a change in settlement strategies from the Late Archaic and that there were changes within the Late Prehistoric period as well. During the early part of the period, residential activities were increasingly restricted to lowland sites, while the uplands were used mostly for hunting-related procurement and processing tasks. This pattern indicates that logistical strategies became more important, but there is no evidence that groups also became more sedentary within the upper Navasota River basin itself. Only one site, McGuire's Garden, contained the kinds of features and other remains that suggest permanent (or nearly so) occupation, with this unusually sedentary use dating to a short interval around A.D. 1300. During the late part of the period, the area apparently saw a return to forager-oriented hunter-gatherer strategies entailing more equable use of upland and lowland settings. Faunal remains indicate that deer, turtles, and rabbits were hunted commonly, and other small mammals, bison, fish, birds, lizards, and snakes were represented as well. Hickory nut shells are by far the most common plant remains. The only evidence for horticulture came from the McGuire's Garden site. Scallorn and Steiner are the most common early arrow point styles, and use of dart points appears to have persisted through the early part of the period (Fields 1995:314). Perdiz is the dominant later arrow point style. Ceramics occur widely but infrequently, being common at only a handful of sites that date mostly to the middle and late parts of the period. Nonetheless, they all relate strongly to Caddoan wares from east of the Trinity River, with the moredistinctive sherds showing typological affinities to early types such as Holly Fine Engraved and Weches Fingernail Impressed and later types such as Maydelle Incised, Killough Pinched, Poyner Engraved, and Patton Engraved. Be- cause Caddoan ceramics abound in these components but evidence for permanent occupations (i.e., structures) is scarce, Fields et al. (1991) suggested that Caddo Indians used most of these sites as base camps to support forays by hunting parties or other procurement and processing task groups, or perhaps groups in transit between the eastern and central parts of the state used them. It is equally plausible, however, that local hunter-gatherer groups created them and that the ceramics resulted from trade or borrowing of ideas about ceramic manufacture and decoration.

At the Calvert Mine in the uplands between the Brazos and Navasota Rivers, the primary component at the single excavated site, 41RT267, appears to date to the early Late Prehistoric period (Robinson and Turpin 1993:2369). It contained Scallorn, Alba, and Granbury points, as well as a single potsherd and several burned rock features, and was interpreted as having been used mostly as a hunting camp with occasional use as a domestic campsite (Robinson and Turpin 1993:71-72). Farther south at the Sandow Mine, both of the excavated sites have Late Prehistoric components, but they do not appear to represent intensive use. Materials diagnostic of this period include small numbers of Scallorn, Perdiz, Alba, and Cuney points; ceramics are scarce to absent (Rogers 1999:96; Rogers and Kotter 1995:136). At Somerville Lake not far to the southeast, arrow points typed as Alba, Cliffton, Granbury, Perdiz, Scallorn, and Young were recovered from the Erwin's Bridge site, along with a handful of undecorated potsherds (Peterson 1965:22-27, 36-43); small numbers of Alba, Scallorn, Perdiz and Bonham points and sandy paste sherds were found at other sites Thoms and Ahr (1996) recorded.

Eastward along the Brazos, an early Late Prehistoric component represented by a few Scallorn points, a small number of sandy paste sherds, and perhaps a few burials was documented at Winnie's Mound (Bowman 1985:43, 50, 61-63). Alba, Perdiz, and Scallorn points were found at 41BU16 nearby, along with both sandy paste and bone- or grog-tempered ceramics (Roemer and Carlson 1987:80-93); some of the burials at 41BU16 could relate to the Late Prehistoric component as well.

At the Gibbons Creek Mine at the southeast edge of the study area, Late Prehistoric 
remains are well represented, with substantial occupations at 41GM281 and 41GM282 and more-limited occupations at several other sites (Rogers 1993:77, 102, 174, 214, 1994:154, 1995:138-143, 164-165). The predominant early and late arrow point styles are Scallorn and Perdiz, respectively. The ceramics from most of the excavated sites (Rogers 1993:102, 160173, 210-212, 1994, 1995:108-123, 168-171) are the sandy paste ware that occurs throughout southeast Texas, first in late Archaic (or Woodland or Early Ceramic) contexts and then in some Late Prehistoric contexts (e.g., on the upper coast). Two sites (41GM281 and 41GM282) also have sizable samples of pottery tempered with grog or bone. Some of these probably are related to the Late Prehistoric San Jacinto ware that occurs on the upper coast to the east and southeast, and small numbers of sherds bear designs similar to those seen on Caddoan pottery to the northeast. Subsistence data from the Gibbons Creek Mine are especially sparse, but hardwood nutshells occur in most sites and liliaceous bulb fragments were recovered from a single site (Rogers 1993:74, 124, 214, 1994:120, 149, 1995:56, 153). Consistent with the lack of cultigens at Gibbons Creek is the low stable carbon isotope value on human remains from a Late Prehistoric burial at 41GM205 (Rogers 1993:D-1 through D-3). The combined evidence indicates that, for the most part, the Gibbons Creek sites represent shortterm residential occupations by hunter-gatherers.

In the Colorado River basin at the south end of the study area, Late Prehistoric components do not seem to be well represented. At the Cummins Creek Mine, only one minor Late Prehistoric occupation is represented by a single untyped arrow point from one of the four sites tested (Kotter et al. 1991:154). The Black Hopper, Kennedy Bluffs, and Bull Pen sites all contained sparse Late Prehistoric materials indicating limited occupations; arrow point types consisted of Scallorn, Perdiz, and Granbury, with none of the sites yielding ceramics (Bement et al. 1989:47; Ensor and MuellerWille 1988:116-118; Fullem 1977:12-13). One of the most substantial excavated Late Prehistoric components in this area was at the Cedar Bridge site at the Fayette Power Plant (Skelton 1977:127-128), where a Toyah occupation represented by Perdiz and Cliffton arrow points, bone-tempered ceramics, and bison bones was sampled. Another important Late Prehistoric component in the area was at the Frisch Auf! site, where Scallorn points and bone-tempered ceramics were found in association with a cemetery (Hester and Collins 1969).

Native American archeological materials dating to the protohistoric and early historic periods are scarce in southern east-central Texas. In fact, materials of this age are so rare as to be almost invisible archeologically in the project areas discussed above. But ethnohistoric accounts make it clear that historic Native Americans, both resident groups and immigrants, occupied the area (Bolton 1970; Campbell 1988; Newcomb 1993). Further, two historic routes from south Texas to east Texas, Camino de los Tejas and Camino Arriba, passed through present-day Milam, Robertson, Leon, Burleson, Madison, and Brazos Counties by the seventeenth and eighteenth centuries (McGraw et al. 1991:9). In the late 1740s and early 1750s, the Spanish located three missions-San Francisco Xavier de Horcasitas, San Ildefonso, and Nuestra Señora de la Candelaria-and a presidio (San Francisco Xavier de Gigedo) near one of these routes, not far from where Brushy Creek joins the Little River in Milam County (Gilmore 1996a, 1996b). The impetus for this action came when members of the Yojuane, Deadose, Mayeye, and Ervipiame asked that a mission be established in their territory. Other Native American groups reportedly associated with the missions were the Asinia, Top, Nabedache, Akokisa, Bidai, and Coco. For a variety of reasons, the Spanish had abandoned their efforts along lower Brushy Creek by the mid-1750s (Newcomb 1993:16-17).

\section{SUMMARY OF IMPACT EVALUATIONS AND SURVEYS}

Forty-six work orders distributed across all four TxDOT Districts were completed (Figure 3). These consisted of 71 Impact Evaluations, 20 Surveys, 5 Surveys with Geoarcheological Evaluation, and 1 work order to produce this report. Combined, these work orders entailed efforts at 59 bridge or relief structure replacements, 16 projects involving primarily road widening or realignment, and 1 wetland mitigation area. During completion of these work orders, five newly discovered or 


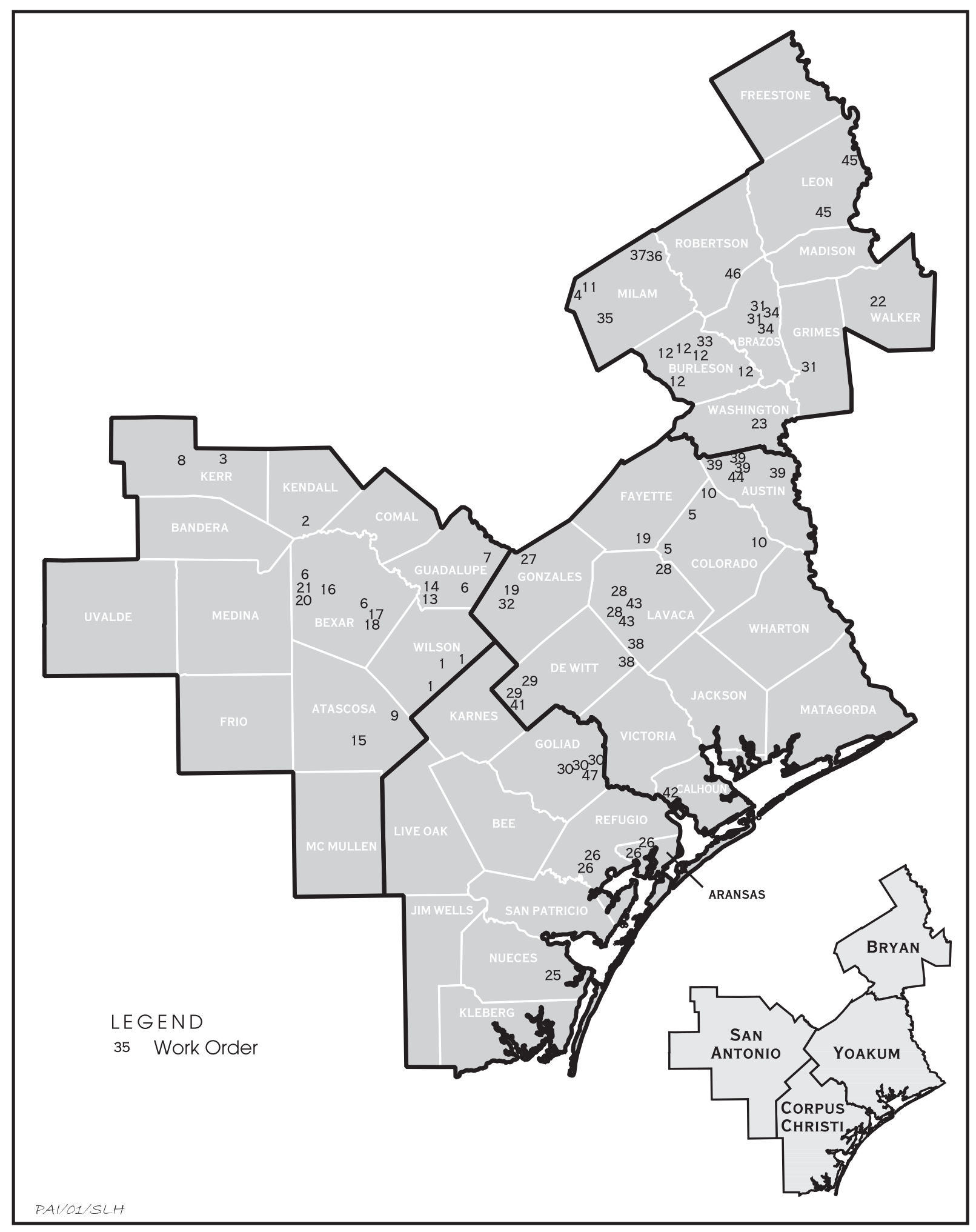

Figure 3. Map of the study area showing the locations of all Impact Evaluations and Surveys. 
previously recorded archeological sites were investigated. This section begins with an outline of the methods used in accomplishing the work orders. Next, the work efforts are summarized in terms of distribution, setting, presence or absence of sites, and recommendations, followed by a discussion of the existing disturbances observed as they relate to the potential for archeological remains in good context at these locations and descriptions of the sites investigated. The section closes with a discussion of the utility of the fieldwork done under these work orders and recommendations for future projects of this kind.

\section{Methods}

Each work order done under this contract began with acquisition of the appropriate USGS map(s), a file search at the Texas Archeological Research Laboratory and the online Texas Archeological Sites Atlas for known sites in and near the project area, and review of project plans to identify impact areas. The field methods employed varied depending on the type of project.

For Impact Evaluations, fieldwork typically consisted of on-the-ground examination of the existing right of way on both sides of the road along the full length of the project area. Where right-of-entry had not been obtained for known or potential impact areas beyond the existing right of way, these areas were inspected visually across fence lines. The ground surface and any disturbed areas (e.g., road cuts, the backdirt of recently placed fiber optic or telephone lines, plowed fields, and so on) within and adjoining the existing right of way were examined for evidence of archeological remains. The primary thrust, however, was to record the kinds and extent of disturbance and determine the likelihood of archeological remains in undisturbed contexts. In most cases, this entailed examining visible stream cutbanks and overall valley geometry to form an opinion about the thickness and extent of Holocene alluvium that could host buried archeological deposits. Typically, shovel tests were not dug since cutbanks provided adequate information on sediment thickness.

For each bridge replacement or other Transportation Activity, a standardized Impact Evaluation form was completed recording anticipated impacts, location and extent of disturbances (e.g., ditches, fill sections, underground utilities, gullying and erosion, and other), location and extent of undisturbed right of way; geologic-geomorphic setting; nature, thickness, and origin of sediments; archeological remains observed; recommendations; personnel; and time spent. Each project area also was documented with color photographs. One or two people did Impact Evaluations, with the typical bridge replacement requiring 1-2 hours. Each of the Impact Evaluations that involved long stretches of highway was carried out as a series of onthe-ground inspections (i.e., at each stream crossing) following the methods outlined above, with the intervening upland areas subjected to windshield inspection.

For Surveys and Surveys with Geoarcheological Evaluations, fieldwork included excavating enough backhoe or Gradall trenches, sometimes accompanied by shovel tests, to constitute a good-faith effort toward determining whether archeological sites are present. As listed in Table 1, 97 trenches were excavated in 23 of the 25 survey areas, ranging from as few as 1 trench to as many as 10 . On 5 surveys, a total of 24 shovel tests were dug in addition to trenches (range $=1-11$ tests). On 2 other surveys, only shovel tests were dug because there are no deep Holocene deposits requiring trenching. Nine tests were excavated in one survey area, and 71 were dug in the other. Only 6 of the surveys were restricted to existing rights of way; substantial parts of these survey areas (usually one-third to two-thirds) were disturbed by existing roads and bridges. These 6 surveys involved excavating 21 trenches and 2 shovel tests. The other 19 surveys were in relatively undisturbed proposed new rights of way or construction easements varying from 0.2 to 25 acres in size (median $=0.9$ acres; total $=88.03$ acres $)$. Seventy-six trenches and 102 shovel tests were excavated in surveying these areas. Trenches and shovel tests usually were placed according to the size and shape of each survey area, distributions of landforms, accessibility, and the locations of known sites rather than at specific intervals.

The trenches were at least $5 \mathrm{~m}$ long and $0.75 \mathrm{~m}$ wide and were usually at least $1.5 \mathrm{~m}$ deep (i.e., the anticipated maximum depth of substantial disturbance). After excavation, their walls were cleaned and examined for cultural materials. Stratigraphic descriptions were 
prepared for selected trenches to characterize the sediments. Shovel tests averaged $30 \mathrm{~cm}$ in diameter and were dug to varying depths depending on depth to bedrock, clay content, and water content. The sediments removed from shovel tests were screened through 1/4-inchmesh hardware cloth. A standardized Survey Summary Form was completed noting whether the survey included a geoarcheological evaluation; describing the areas subjected to surface survey and visibility, indicating the number, depth, and placement of shovel tests and trenches; listing the cultural materials observed and sites recorded; providing assessments and recommendations; and noting the personnel and time needed for the survey. Other documentation consisted of color photographs, Temporary Site Forms (for eventual submittal to the Texas Archeological Research Laboratory in TexSite format), stratigraphic profile descriptions, and project plans showing the locations of all trenches, shovel tests, and sites. Surveys usually were done by two-person crews; on Surveys with Geoarcheological Evaluations, one member of the crew was a geoarcheologist. The time required to complete the surveys varied depending on their size, the number of trenches and shovel tests excavated, and what was found. The range was 3-52 person-hours, with the median being 6.5 person-hours (excludes time spent by TxDOT personnel, including backhoe and Gradall operators).

\section{Synopsis of Work Orders}

As listed in Table 1, 13 of the 45 work orders involving fieldwork were in the Bryan District (Brazos, Burleson, Grimes, Leon, Milam, Robertson, Walker, and Washington Counties), 4 were in the Corpus Christi District (Aransas, Goliad, Nueces, and Refugio Counties), 15 were in the San Antonio District (Atascosa, Bexar, Guadalupe, Kendall, Kerr, and Wilson Counties), and 13 were in the Yoakum District (Austin, Colorado, DeWitt, Fayette, Gonzales, and Lavaca Counties). The projects in the Bryan District consisted of 12 Impact Evaluations, 10 Surveys, and 2 Surveys with Geoarcheological Evaluations for replacing 21 bridges and widening 1 road. In the Corpus Christi District, the work orders were for 12 Impact Evaluations and 1 Survey on 7 bridge replacements and 2 projects involving road widening ( 1 with con- struction of bypasses). The San Antonio District work orders consisted of 26 Impact Evaluations, 1 Survey, and 3 Surveys with Geoarcheological Evaluations entailing 9 bridge replacements and 12 road-widening projects. In the Yoakum District, 21 Impact Evaluations and 8 Surveys focused on replacement of 21 bridges, 1 roadwidening project, and 1 wetland mitigation project.

Not surprising given the focus on bridge replacements, many of the projects $(n=68)$ were restricted to Holocene alluvial settings (see Table 1). Another 18 Impact Evaluations and Surveys encompassed upland margins as well as Holocene alluvium, with the uplands mapped as a variety of Tertiary and Quaternary formations (Beaumont, Fleming, Goliad, and Willis), Pleistocene fluviatile terrace deposits, and the Upper Cretaceous Austin Chalk and Pecan Gap Chalk Formations. The 10 projects that were mostly in upland areas crossed the Pleistocene Lissie Formation, Pleistocene fluviatile terrace deposits, and the Eocene Wilcox, Carrizo Sand, Reklaw, Yegua, Manning, Wellborn, and Caddell Formations. A variety of soils are mapped for the project areas, ranging from loamy to clayey, sometimes stony, often shallow soils in the western part of the study area to dark, calcareous, clayey soils of the Blackland Prairie to loamy to sandy soils with clayey substrates in the Oak Woodlands to clayey to sandy soils, some with indurated caliche, in the south Texas Brush Country. Among the mapped Holocene alluvial soils in the areas examined during these work orders are Aransas clay, Boerne silt loam, Bosque clay loam, Brazos fine sand, Christine clay loam, Frio silty clay loam, Gowen clay loam, Meguin silty clay, Navaca clay, Oakalla silty clay loam, Odem fine sandy loam, Orif silt loam, Pursley loam, Trinity clay, and Uhland loam (see Table 1). Upland and old terrace soils in these areas include Axtell fine sandy loam, Burleson clay, Clodine loam, Crockett fine sandy loam, Hockley fine sandy loam, Houston Black clay, Jedd gravelly sandy loam, Katy fine sandy loam, Lewisville silty clay, Lufkin loam, Miguel fine sandy loam, Patrick clay loam, Queeny gravelly loam, Tabor fine sandy loam, Tarrant clay loam, Webb fine sandy loam, and Wilson silt loam.

Most of the Impact Evaluations and Surveys $(n=79)$ were in rural areas where adjoining lands were undeveloped and in pastures or 


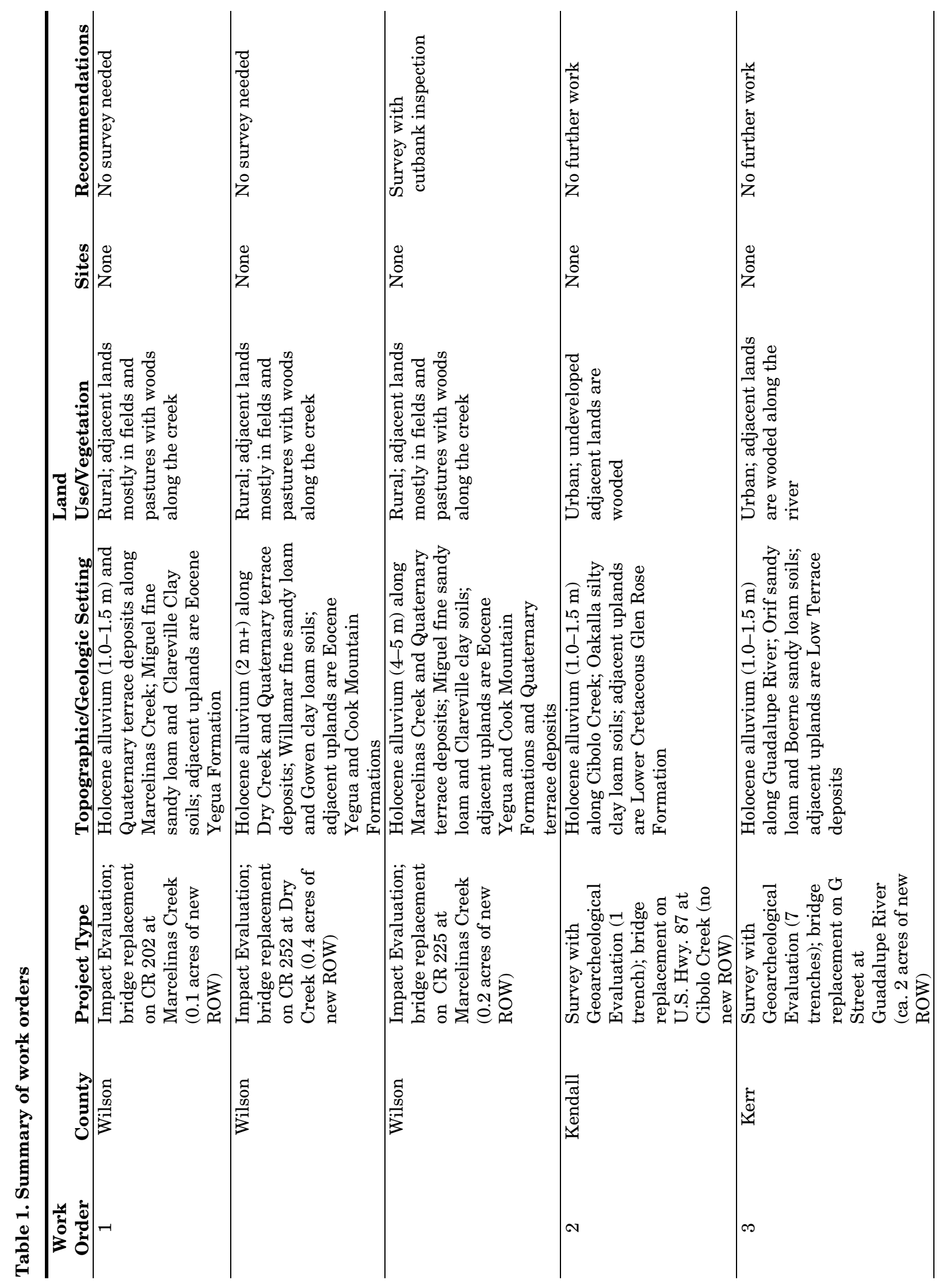




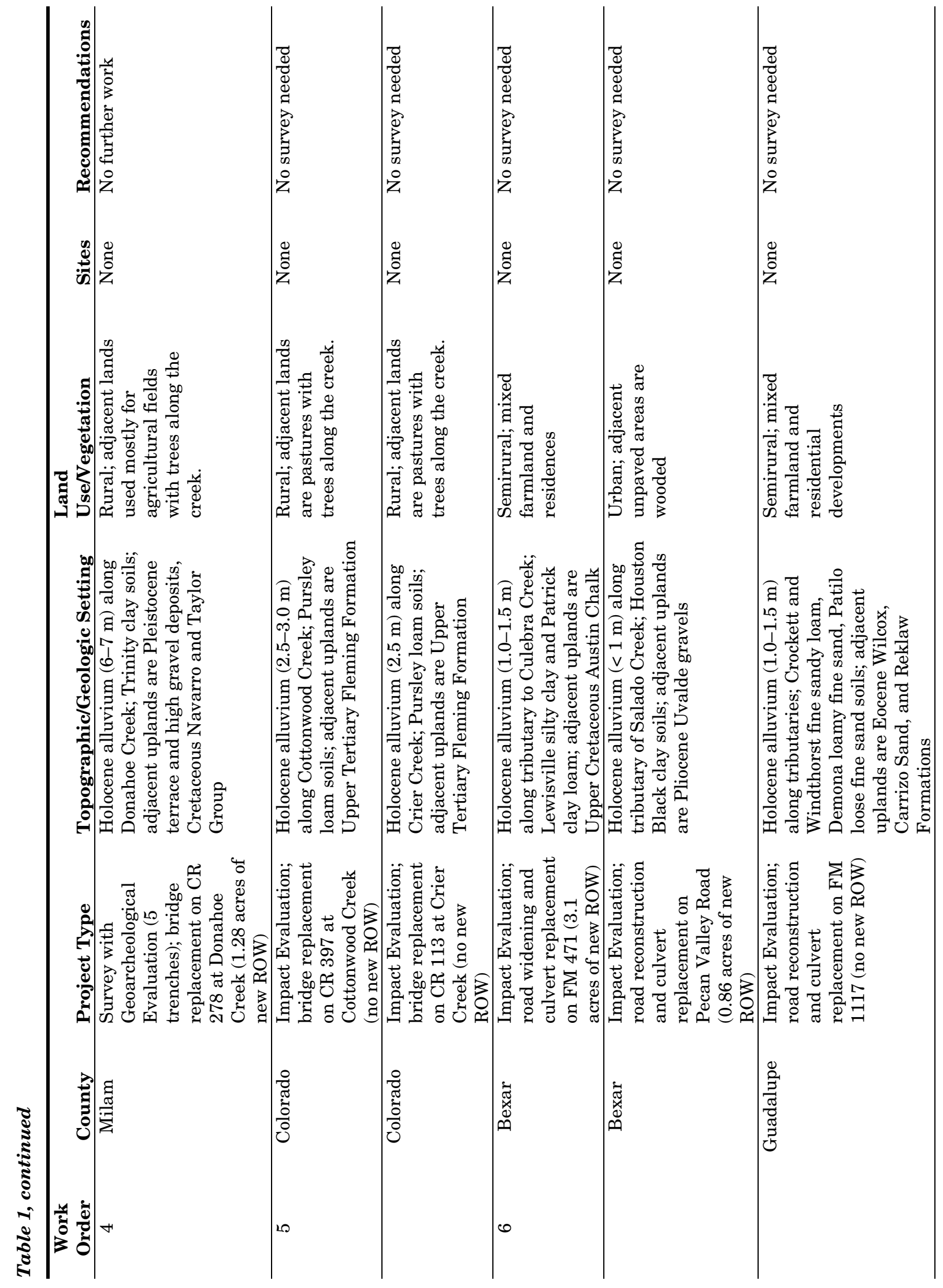




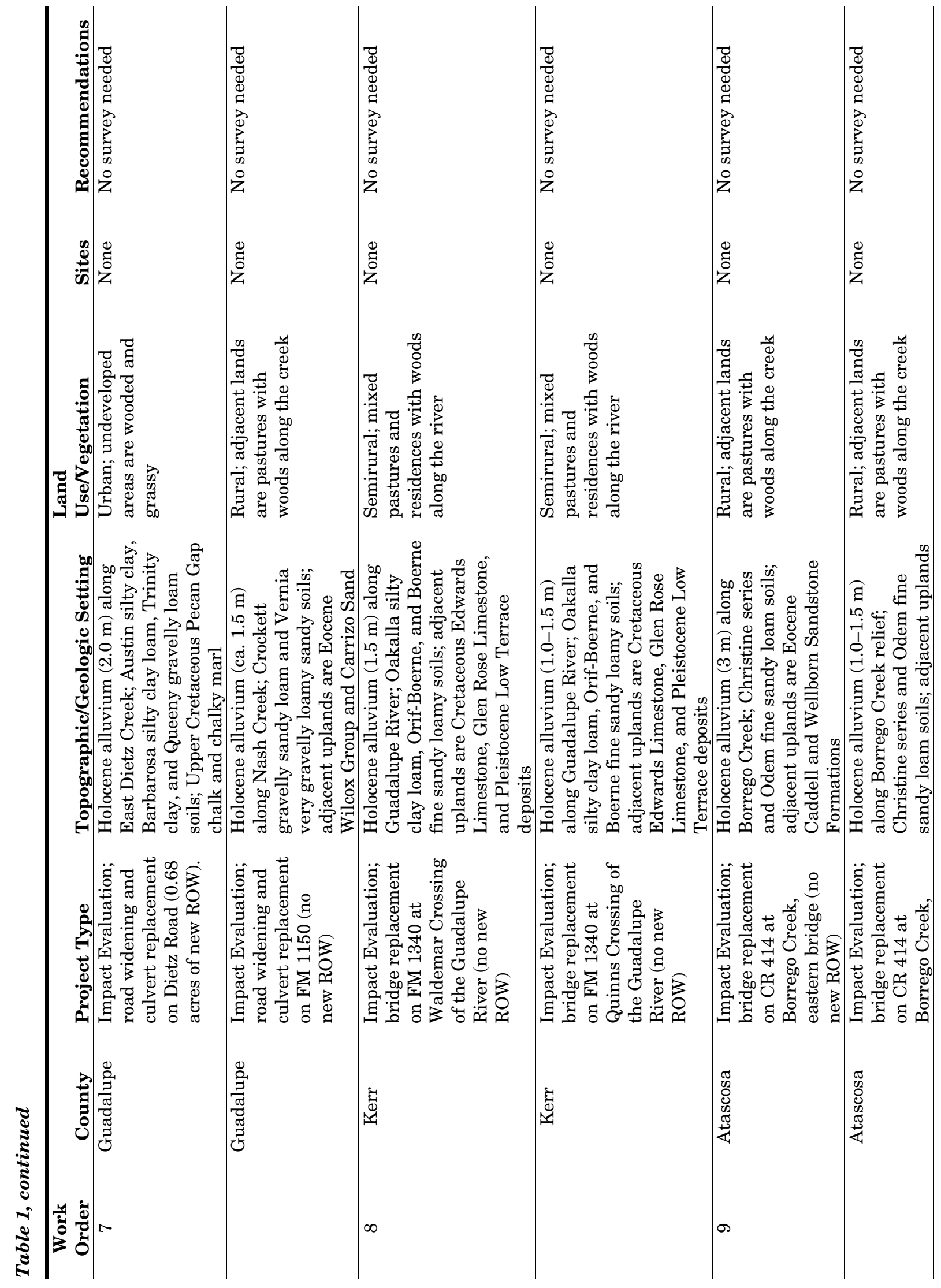




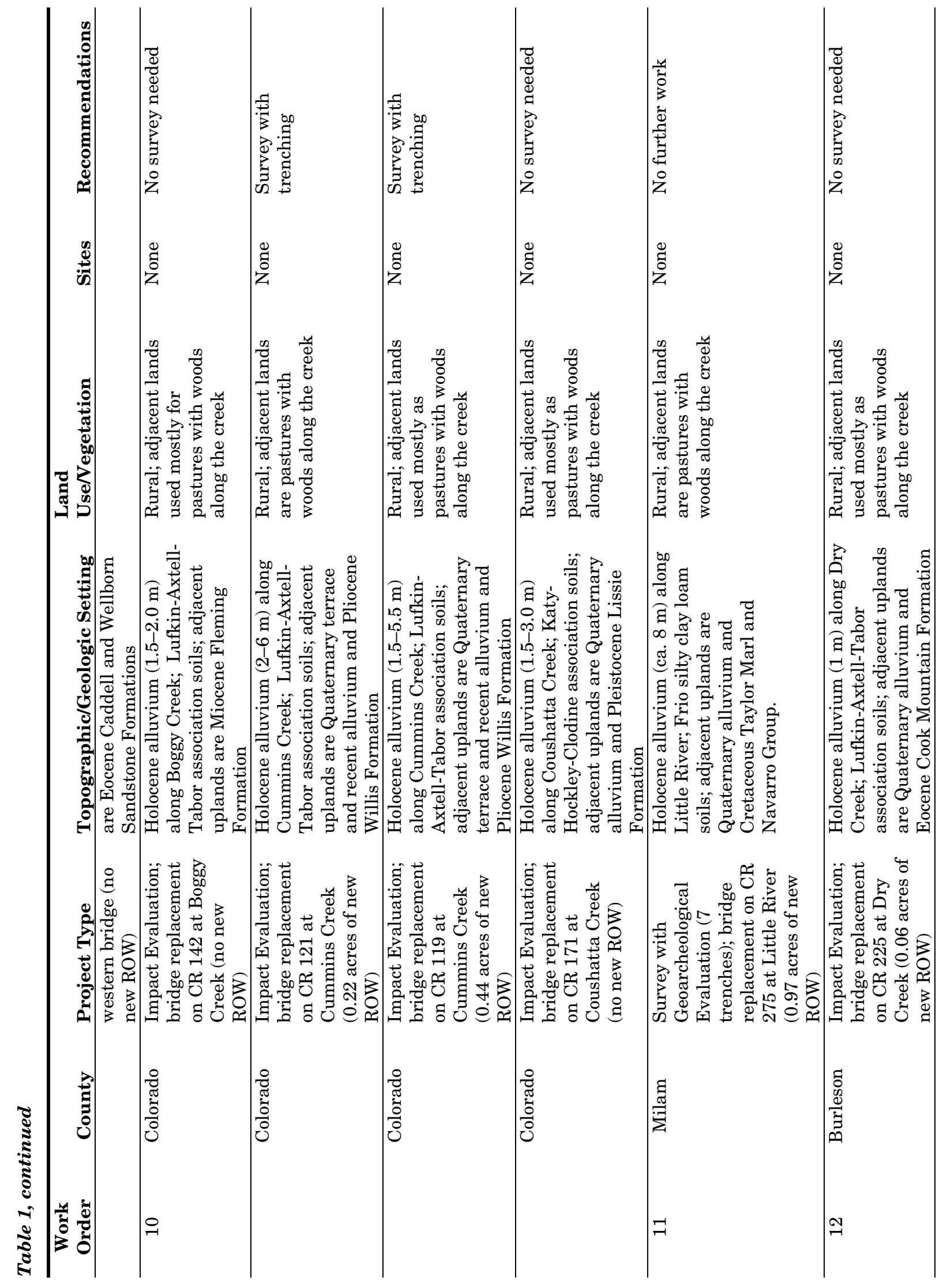




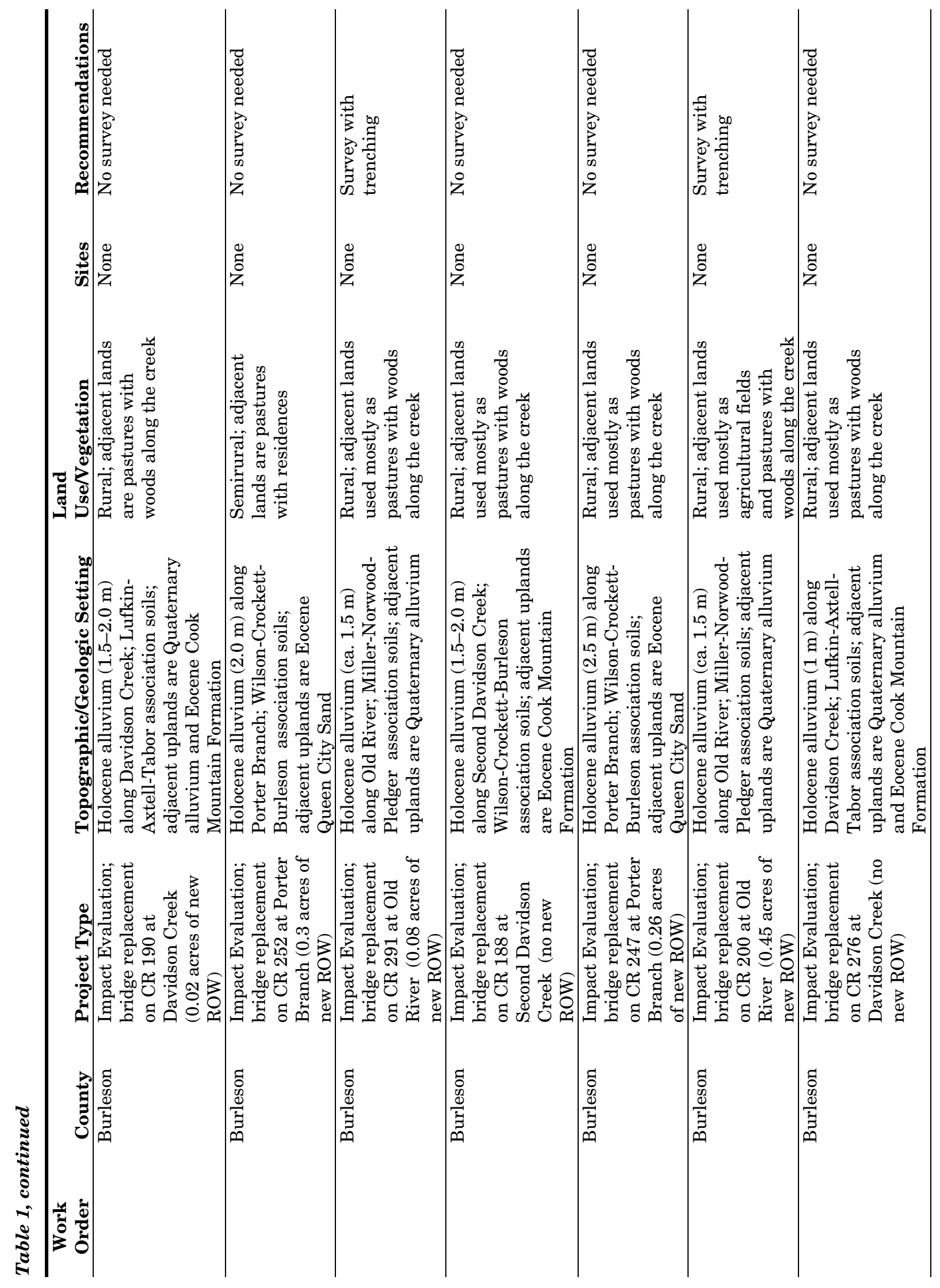




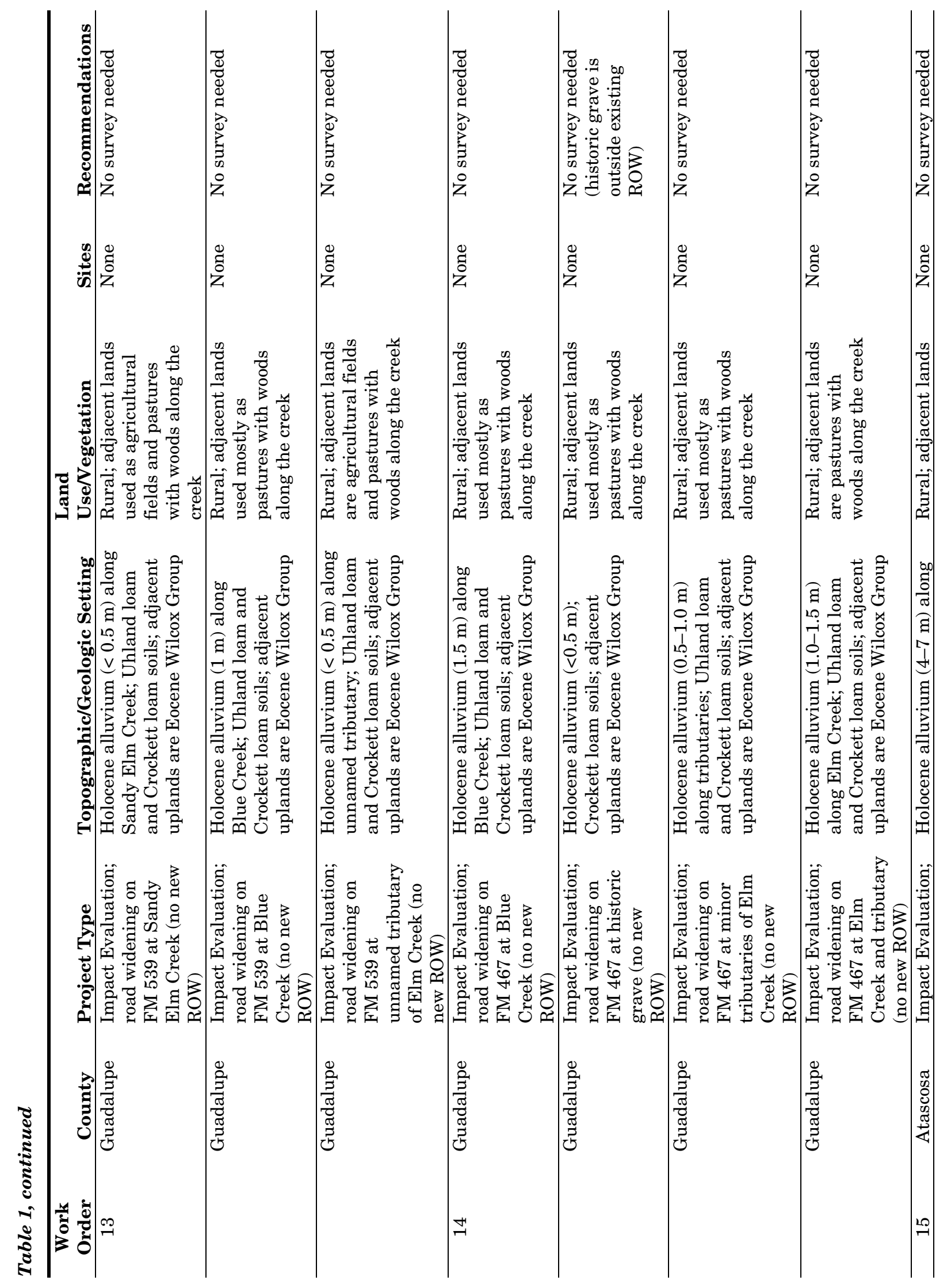




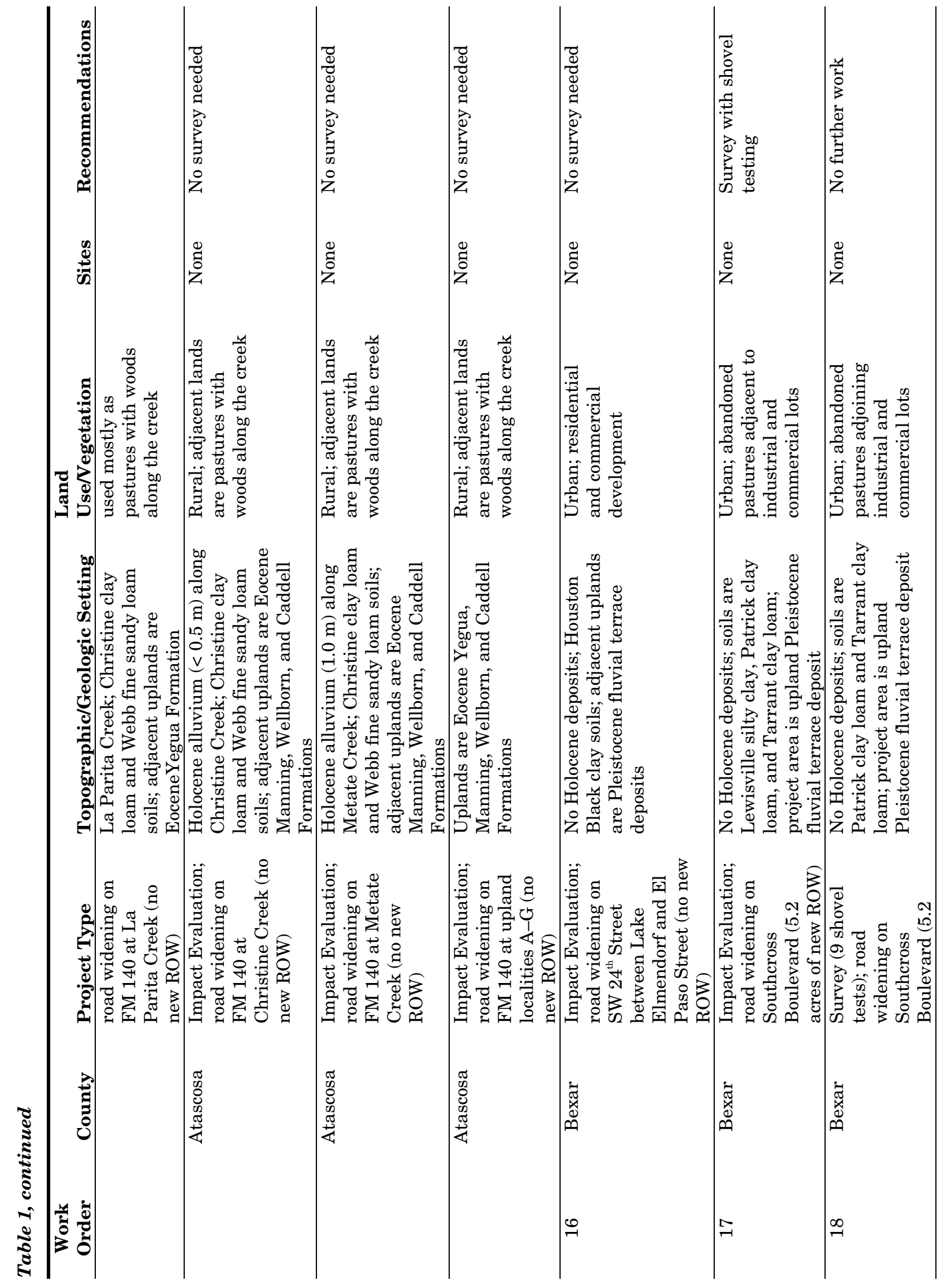




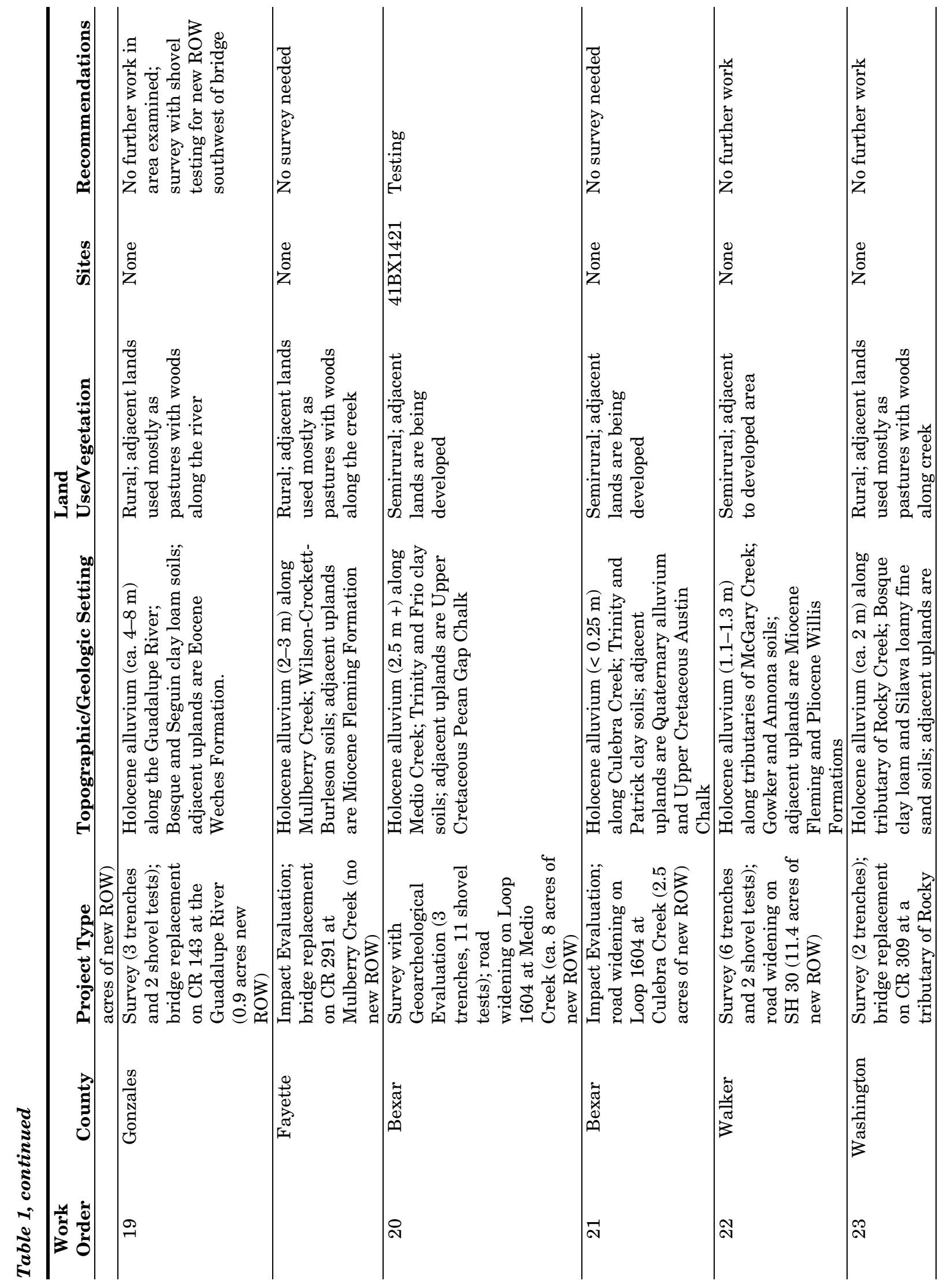




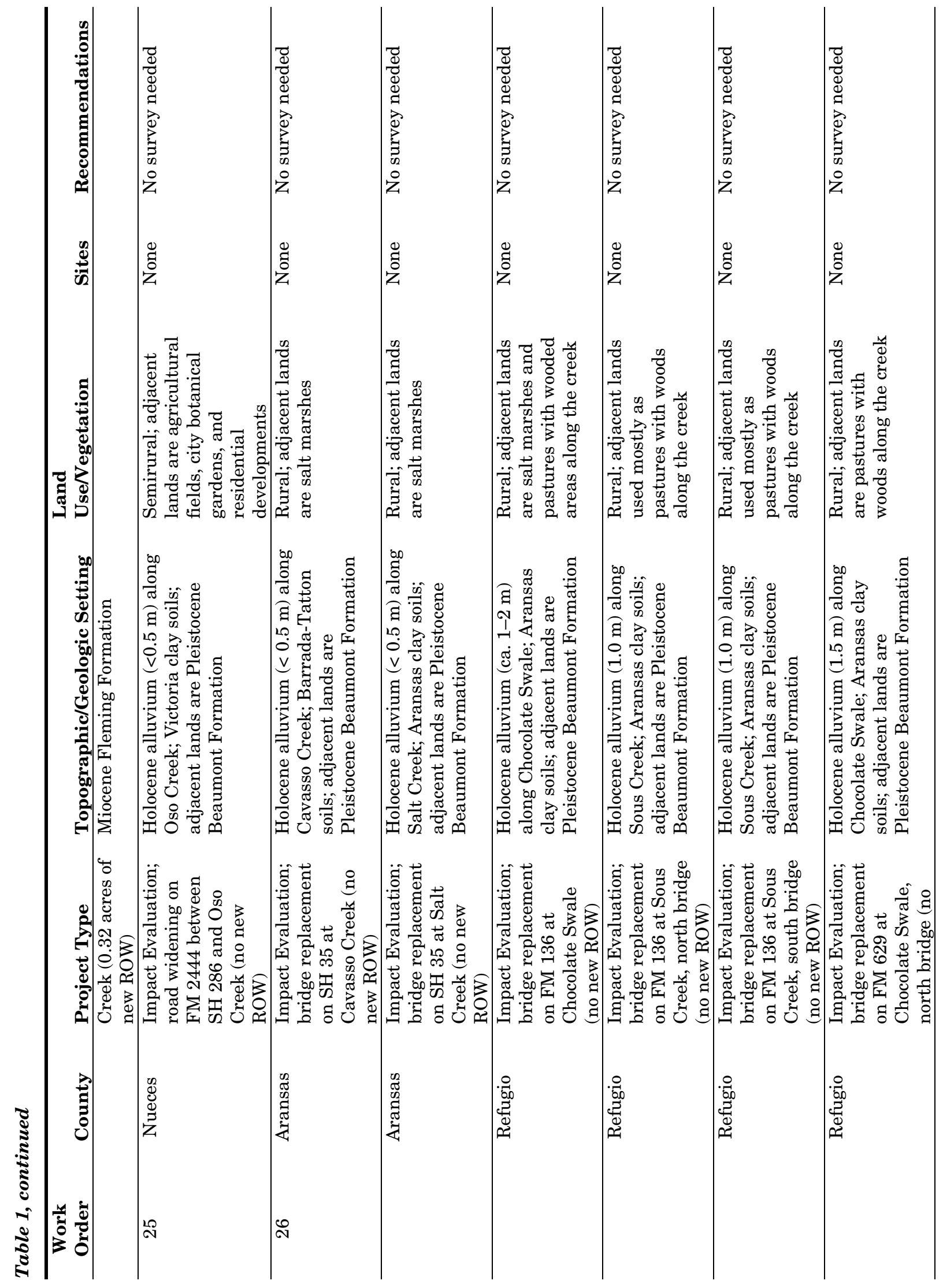




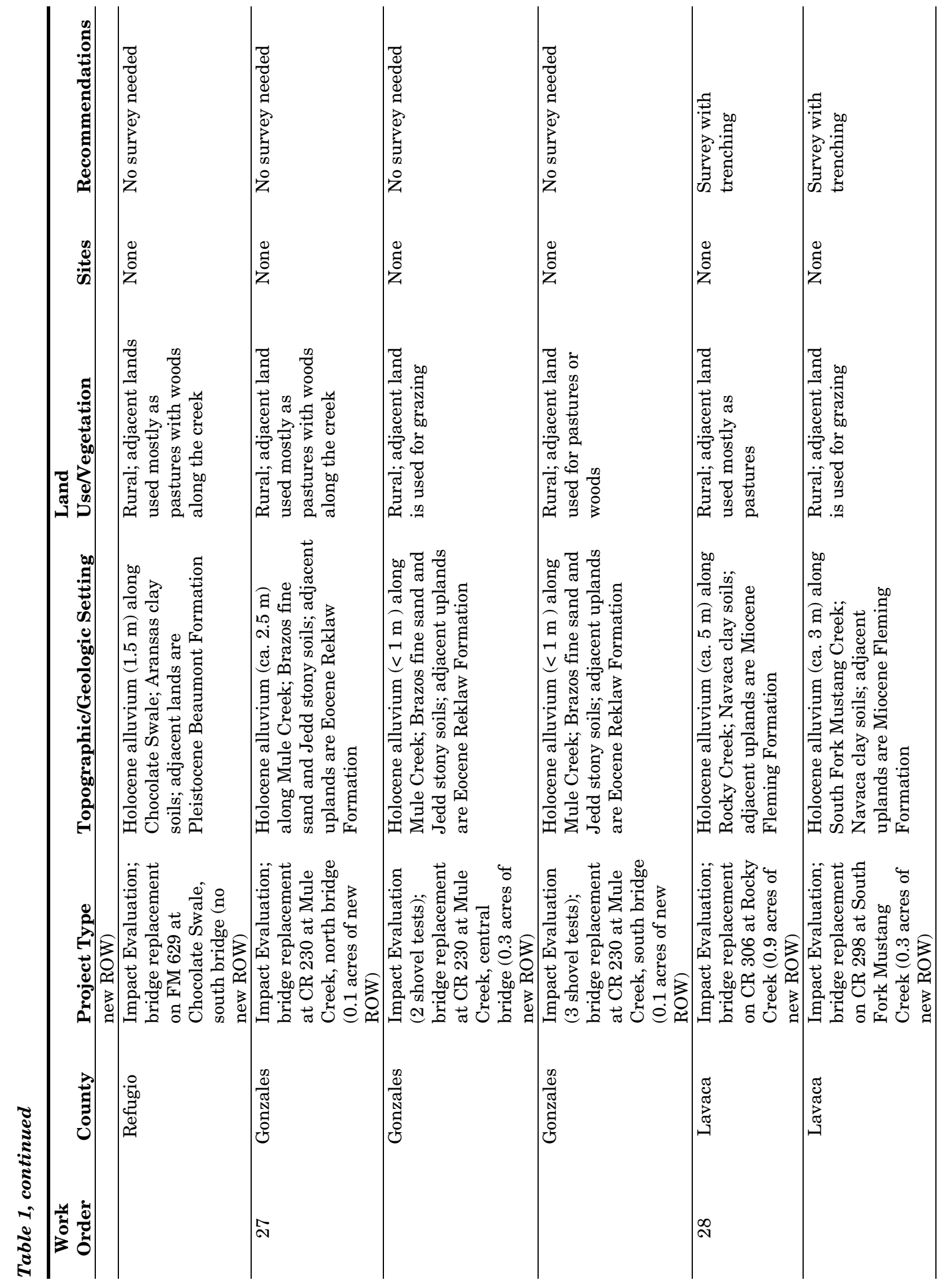




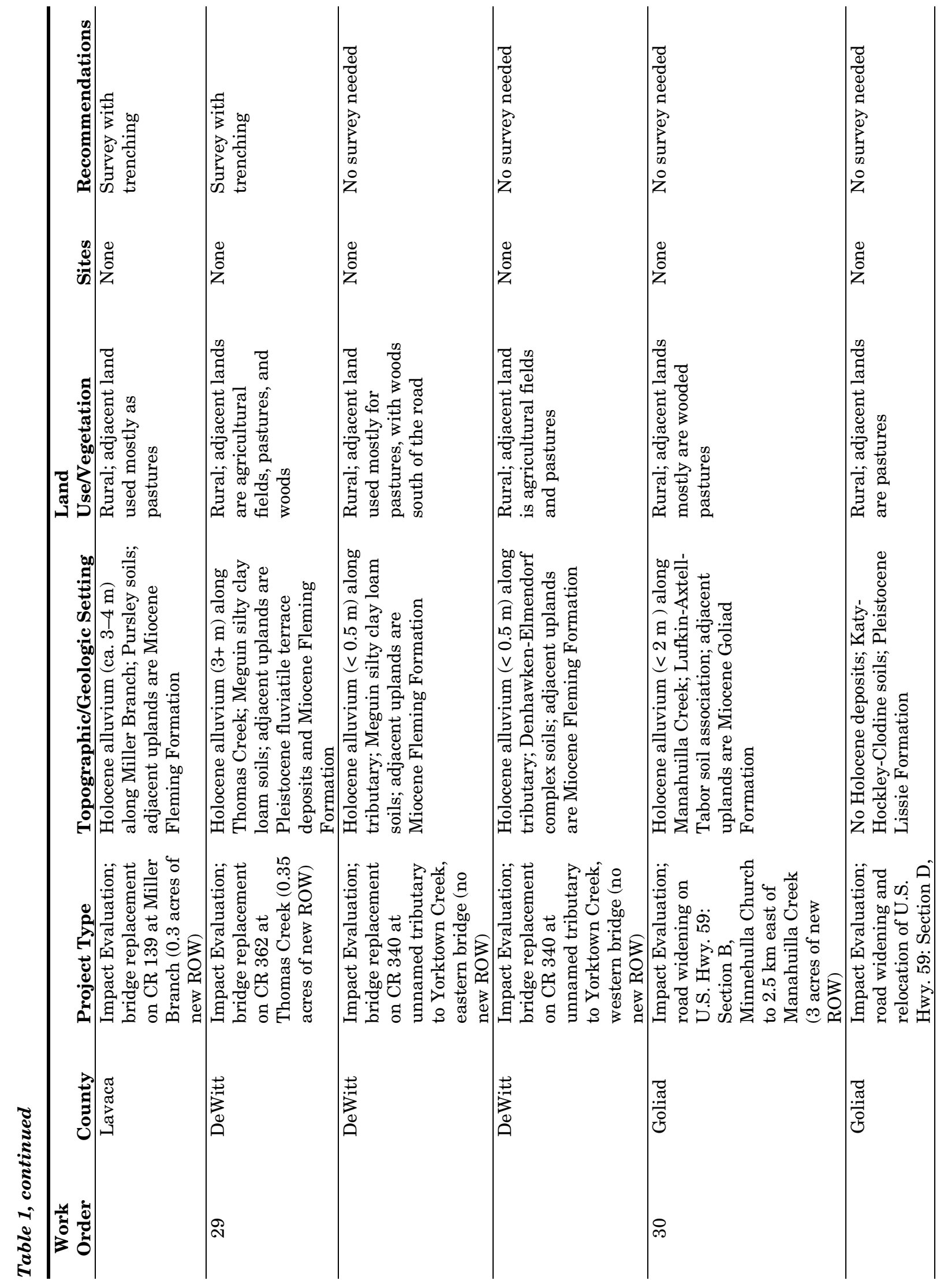




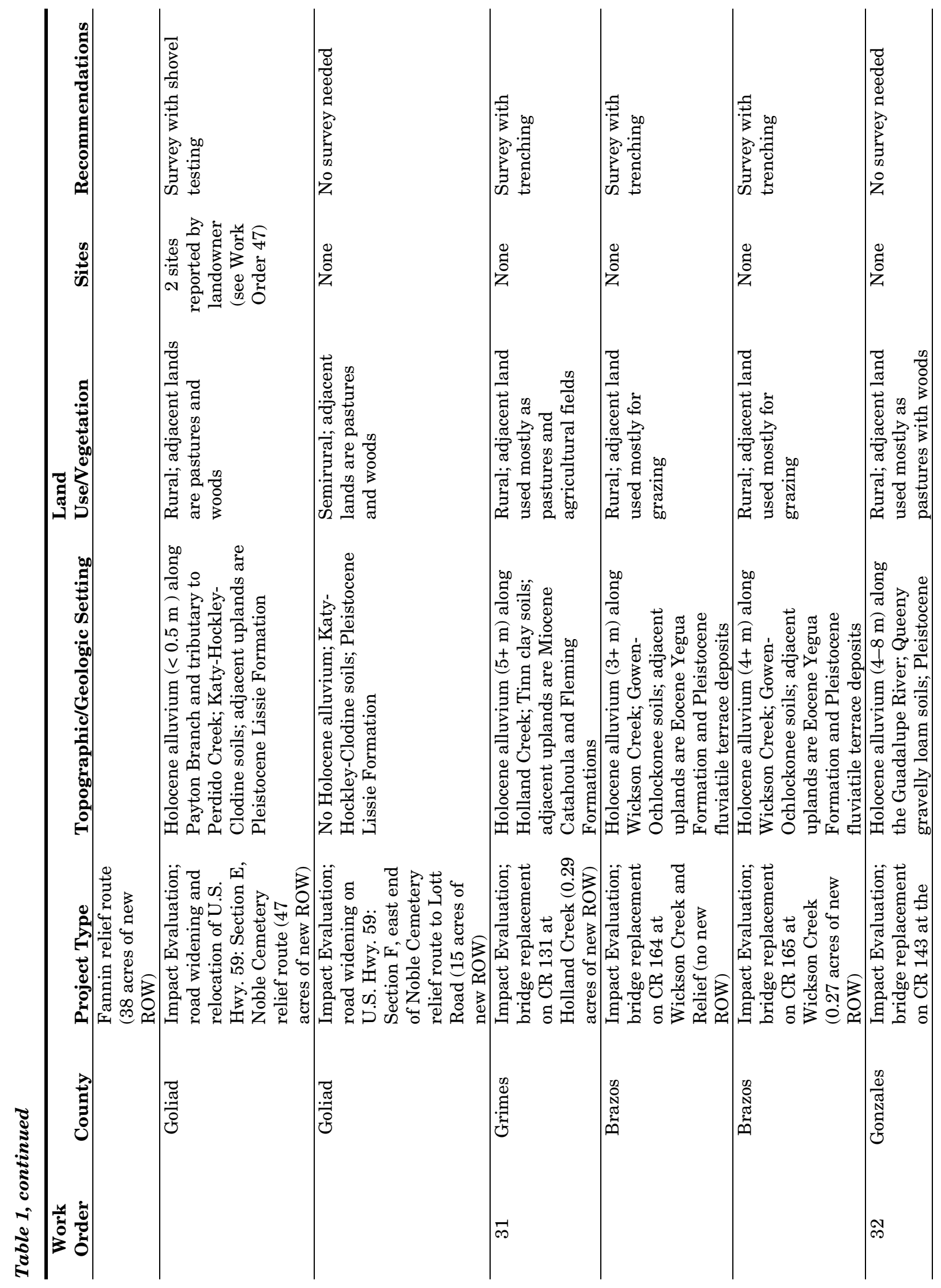




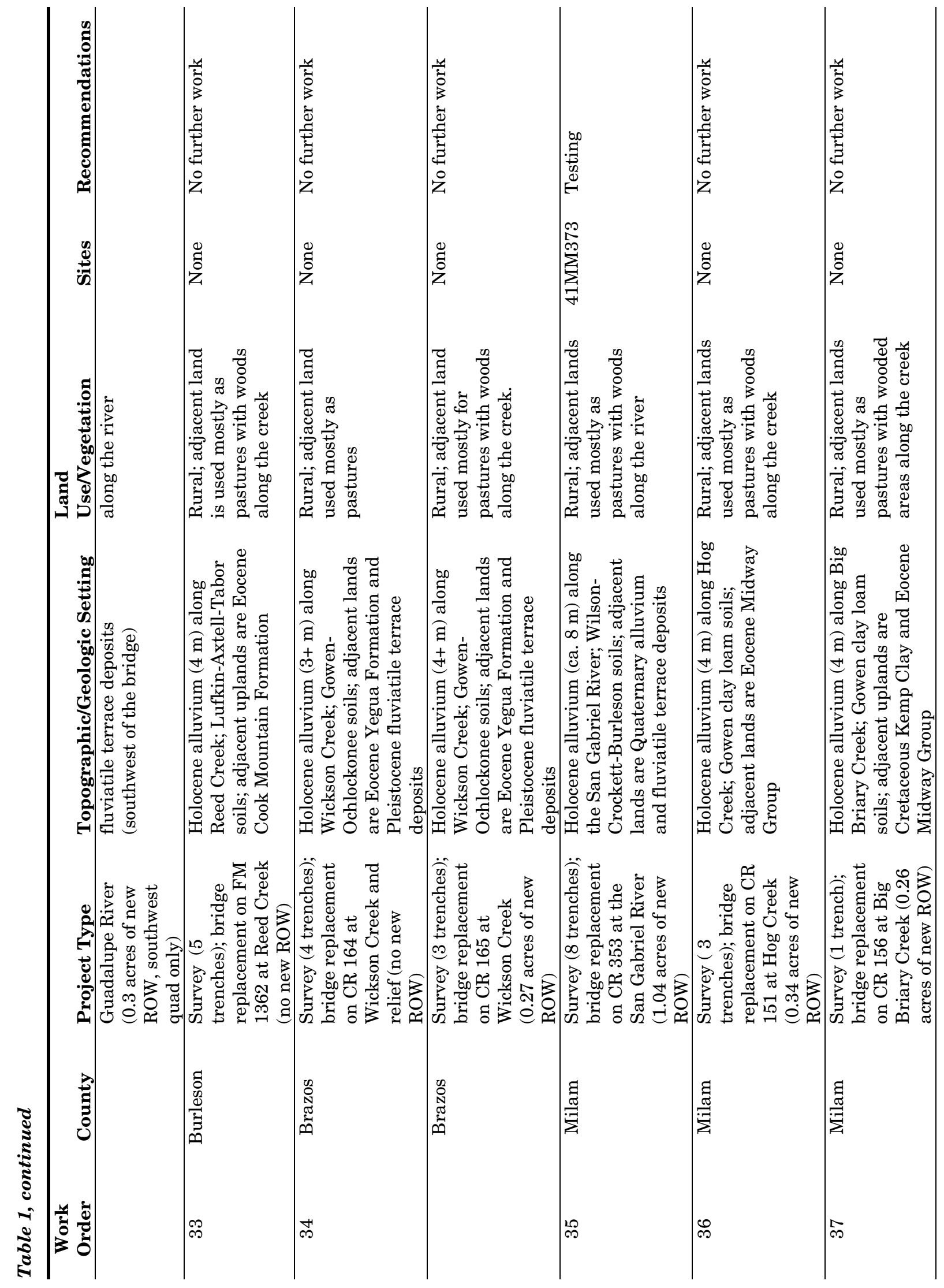




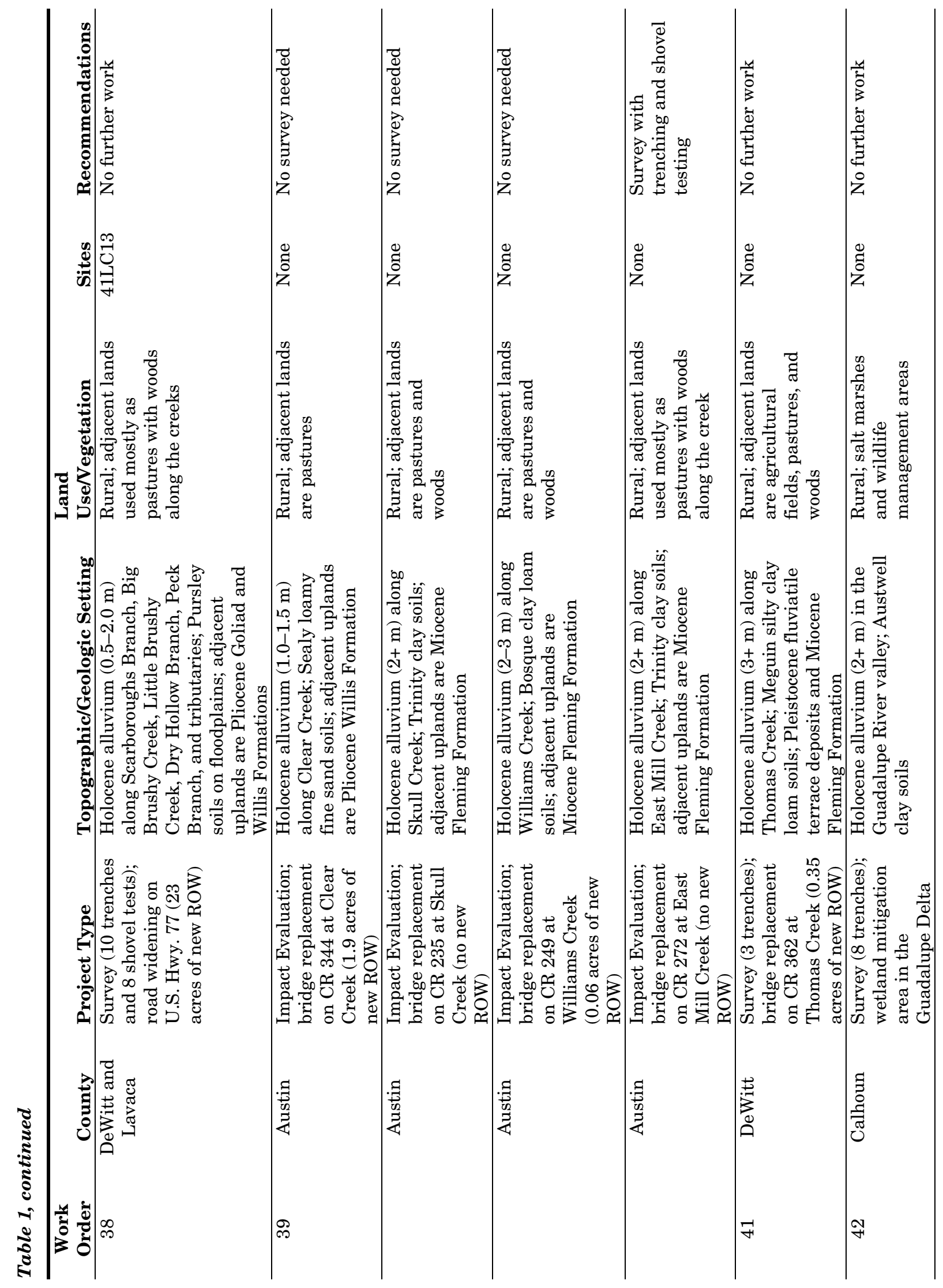




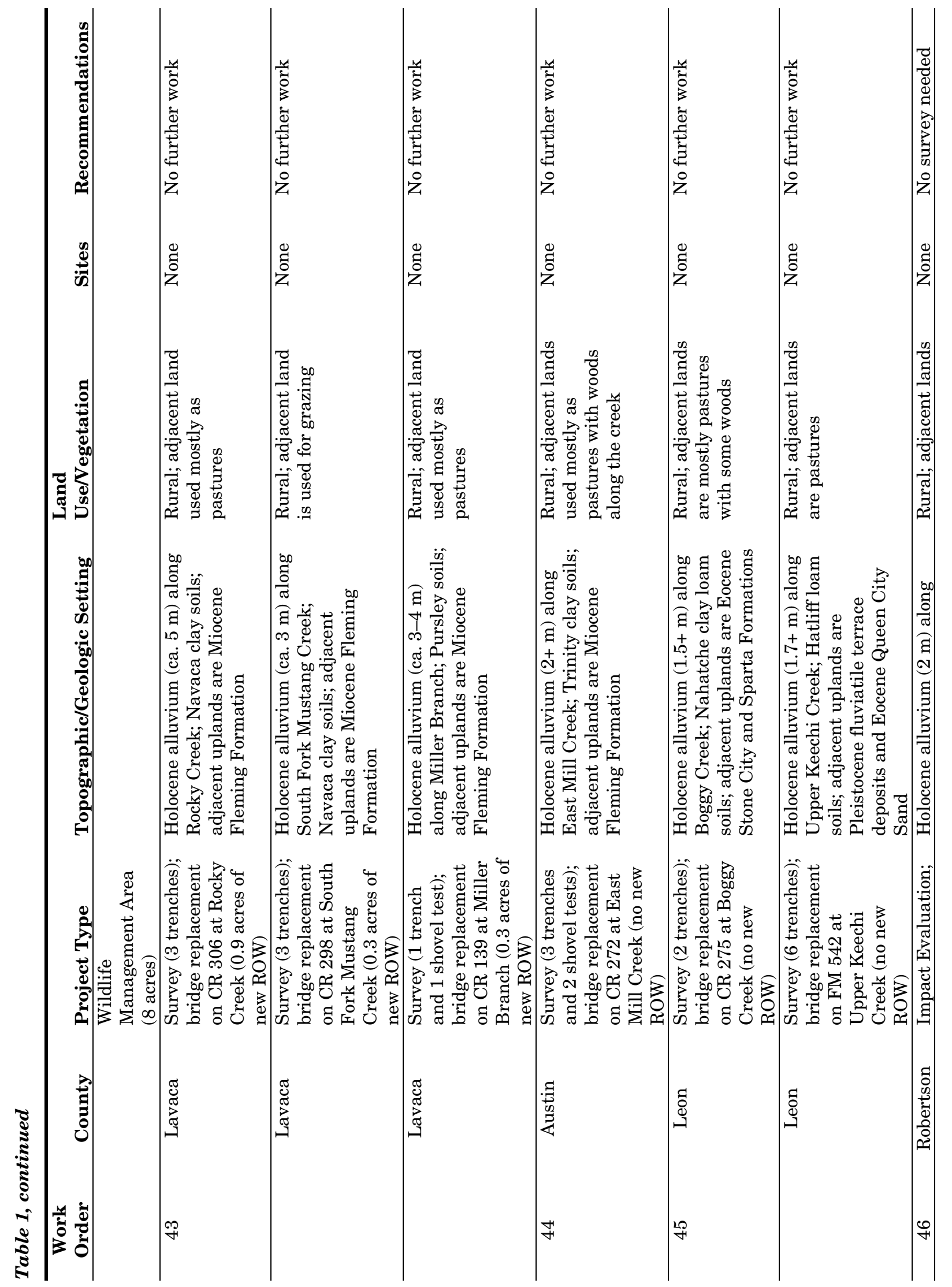




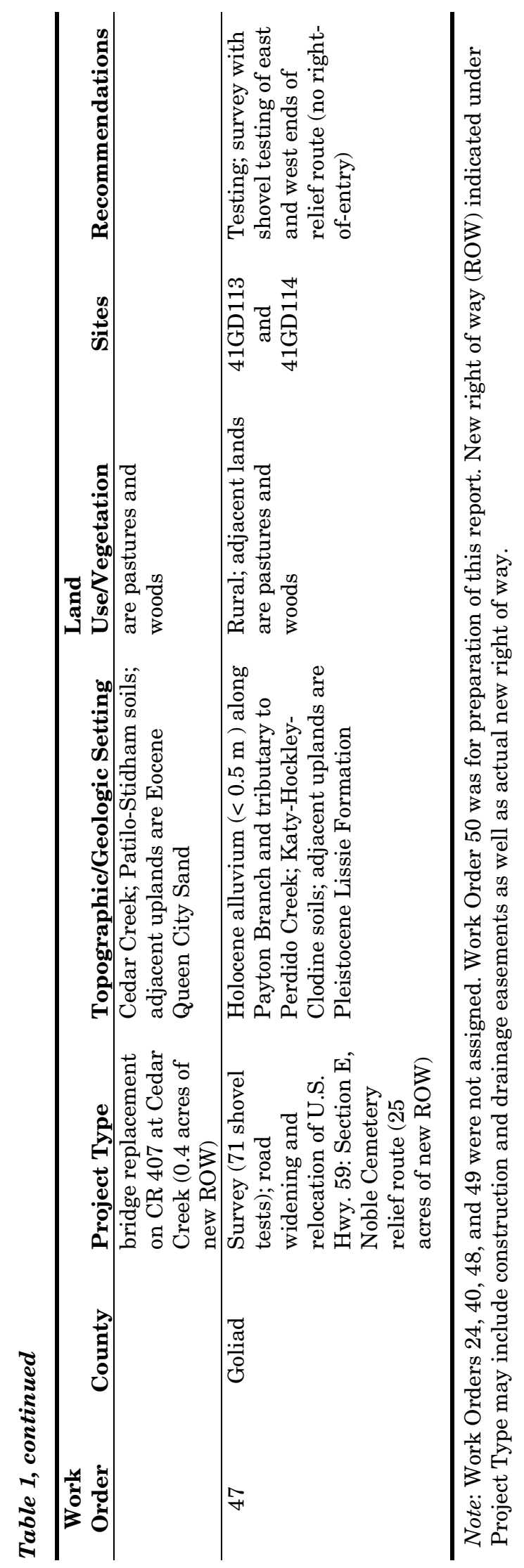


woods (see Table 1). Ten projects were in settings that can be classified as semirural (i.e., largely undeveloped but near low-density residential or commercial areas). Seven project areas were in urban settings (i.e., the cities of Boerne, Kerrville, San Antonio, and Shertz).

Fifteen of the Impact Evaluations resulted in recommendations that an archeological survey be completed before construction (see Table 1 ). This was the case most often when construction plans called for new right of way or an easement across areas with substantial (i.e., at least $1 \mathrm{~m}$ thick), undisturbed Holocene deposits that could host buried, prehistoric archeological remains in good context. The remaining $56 \mathrm{Im}$ pact Evaluations resulted in a recommendation that no survey be required based on the extent of disturbance and the limited potential for sites with good integrity. In most cases $(n=36)$, these Transportation Activities will require no new rights of way or easements, with all construction-related disturbances restricted to the existing rights of way.

Three of the Surveys investigated sites that were recommended for testing to assess eligibility for listing in the National Register of Historic Places and designation as State Archeological Landmarks (see Table 1). The other 22 Surveys either did not find any archeological sites or investigated sites that could be assessed as ineligible for National Register listing and State Archeological Landmark designation using the survey data.

\section{Impacts and Site Potential}

A primary thrust of the Surveys and especially of the Impact Evaluations performed under this contract was documentation of existing disturbances that would affect the potential of each project area to contain archeological sites with sufficient integrity to be eligible for listing in the National Register of Historic Places or designation as a State Archeological Landmark. In general, four kinds of disturbances were observed consistently within existing rights of way: fill sections, ditches, gullies, and underground utilities (Figure 4).

Fill sections to elevate the approaches to bridges above the adjoining floodplains were present at most of the bridge replacement project areas (Table 2). These fill sections ranged from less than $0.5 \mathrm{~m}$ in thickness to as much as
$10 \mathrm{~m}$, but most extended $0.5-2.0 \mathrm{~m}$ above the natural surface. Horizontally, they extended as little as $5 \mathrm{~m}$ from each end of a bridge to as much as several hundred meters, depending on the size of the valley and the kind of road. The higher and longer fill sections tended to be associated with the larger roads and larger streams. Typically, fill sections extended at least several meters beyond the edges of the pavement, in some cases occupying almost all of the existing right of way. It is difficult to quantify how much disturbance is associated with the placement of fill sections, but it is assumed that at least the upper $0.5 \mathrm{~m}$ of sediment beneath and beside fill sections is disturbed by heavy machinery during construction and later by compaction. Presumably, the larger the fill section, the deeper the disturbance.

In many cases, fill sections were bordered on both sides by shallow drainage ditches (see Table 2). These usually were less than $1 \mathrm{~m}$ deep, and often less than $0.5 \mathrm{~m}$, and they were up to several meters wide. Vegetation covered most, and thus they did not offer any subsurface visibility, but a few that recently had been maintained exposed subsurface deposits. Better exposures typically were provided by gully erosion, which occurred often in the bottoms of ditches running along the edges of fill sections and breaching the creek banks. In many cases, such gullies were present at one or more corners of a bridge, often extending to depths of $1 \mathrm{~m}$ or more (see Table 2).

The fourth kind of disturbance observed consistently was underground utilities. These were present in many project areas, with the most common kind being buried telephone or fiber optic lines (see Table 2). These almost always were at one or both edges of the existing right of way and were marked by signs or areas of recent disturbance from placement of the lines. Based on the extent of the recent disturbance, it appears that trenching for these lines usually had disrupted an area $0.5 \mathrm{~m}$ or less in width. Presumably, they vary in depth, with most probably being no deeper than $1 \mathrm{~m}$. Moreextensive disturbance probably is associated with other kinds of underground utilities, including water lines, sewer lines, and gas pipelines. These were not as ubiquitous as telephone and fiber optic lines, although some (especially water lines) may not be marked with signs as consistently as telephone and fiber optic lines. 


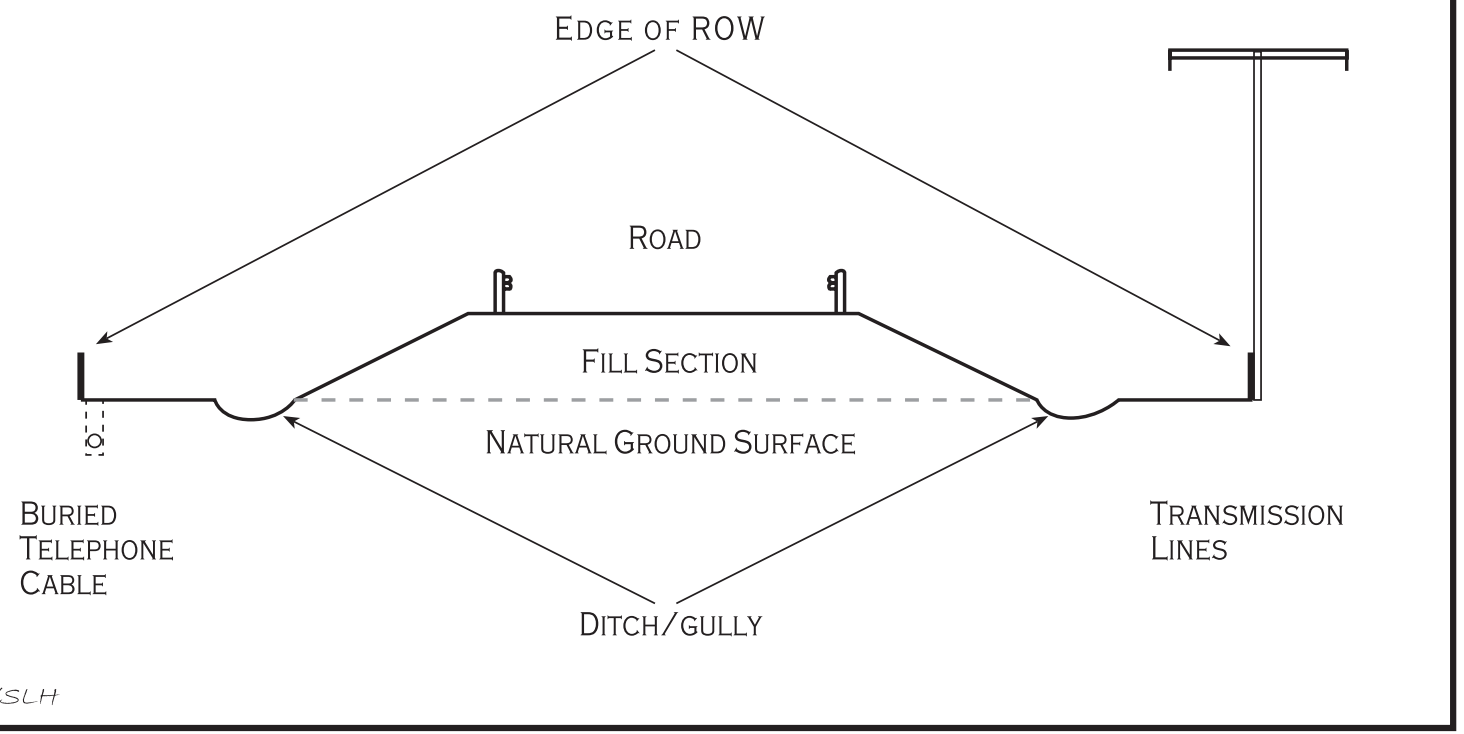

Figure 4. Schematic cross section of a bridge approach showing common disturbance factors.

A variety of other disturbances were noted less frequently (see Table 2). These included the following: constructed earthen berms to control runoff or creek flooding; severe erosion of creek banks; slope erosion; flood scouring; deposition of flood debris piles; uprooted trees; push piles from minor earth moving; road cutting; erosion associated with use of low-water crossings; creek channelization; placement of fill piles; the construction of dirt, gravel, or paved driveways, often with associated culverts, to access fields, businesses, and residences beyond existing rights of way; construction of boat ramps; plowing of fields by existing rights of way; use of two-track roads; tire ruts; cattle trampling; construction and maintenance of railroad beds near existing rights of way; excavation of stock tanks on adjoining lands; excavation of borrow pits; and nearby commercial or residential development. Overhead transmission and telephone lines, which were observed along the edges of the rights of way at many locations, occurred more frequently but caused little disturbance.

By combining information on the observed or presumed depth of these disturbance factors, their horizontal extent, the size of the existing right of way, and planned new right of way or construction easements, it was possible to identify areas where disturbance has been so se- vere that archeological remains (if present) would be unlikely to survive with good integritythat is, areas where survey was not warranted. Areas lacking such disturbance typically were recommended for survey, especially if the potential for sites was considered high (i.e., on terraces or upland margins overlooking medium-sized and larger water courses) or if there were thick alluvial deposits that could host archeological remains in stratified contexts present.

\section{Sites Investigated}

Five archeological sites were investigated during four work orders. Descriptions of these sites, drawn from the original reports included on CD-ROM in Appendix B, are presented below. Table 3 summarizes the materials observed and recommendations made.

\section{Work Order 20, 41BX1421}

Site 41BX1421 was discovered on the $\mathrm{T}_{2}$ terrace within the channel easement and new right of way west of Loop 1604 at Medio Creek in Bexar County. It is $37 \times 38 \mathrm{~m}$ in size and is limited to the area between Medio Creek and its southern tributary. Lithic debitage, a biface, modified flakes, cores, and tested cobbles were 


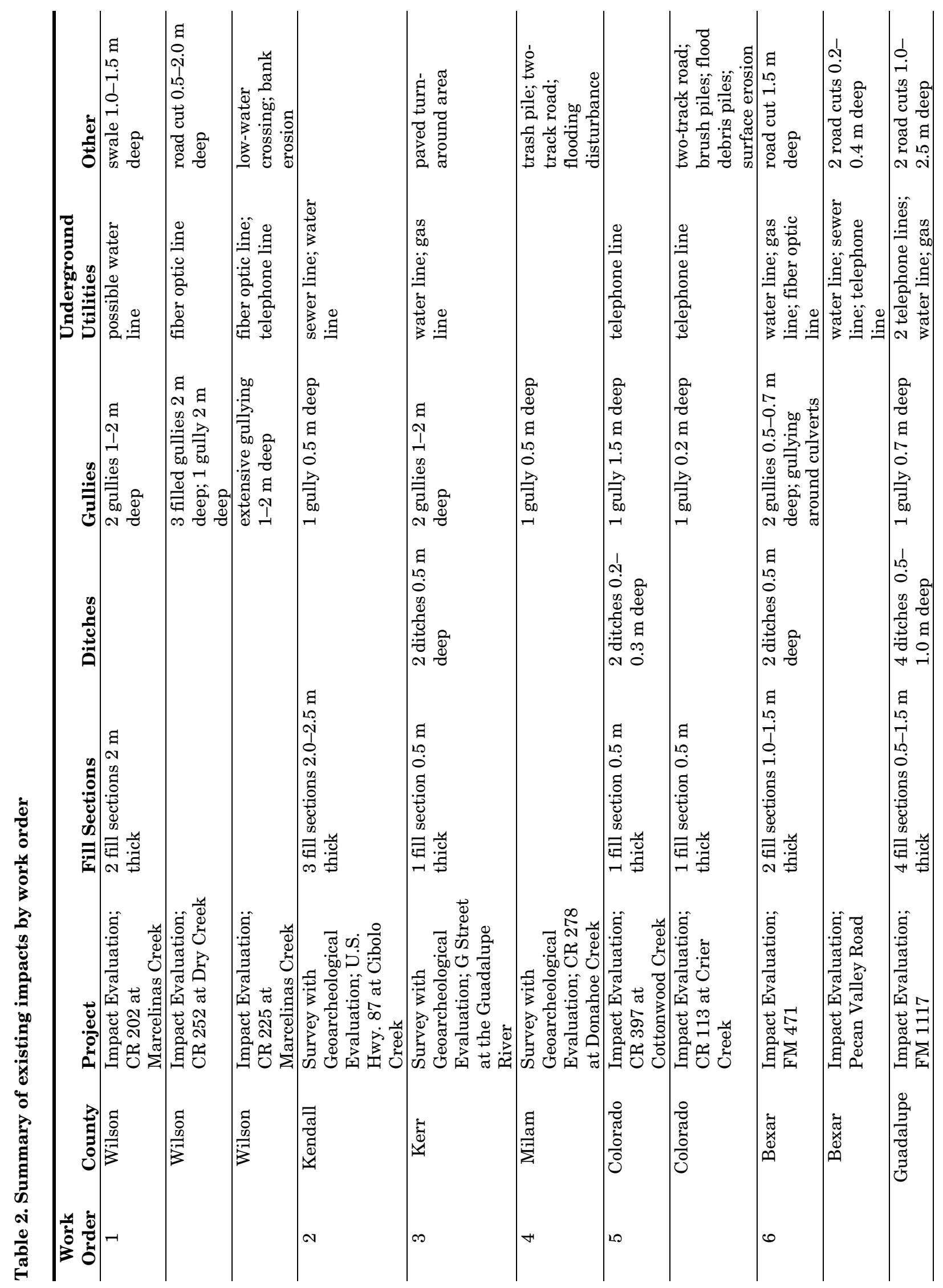




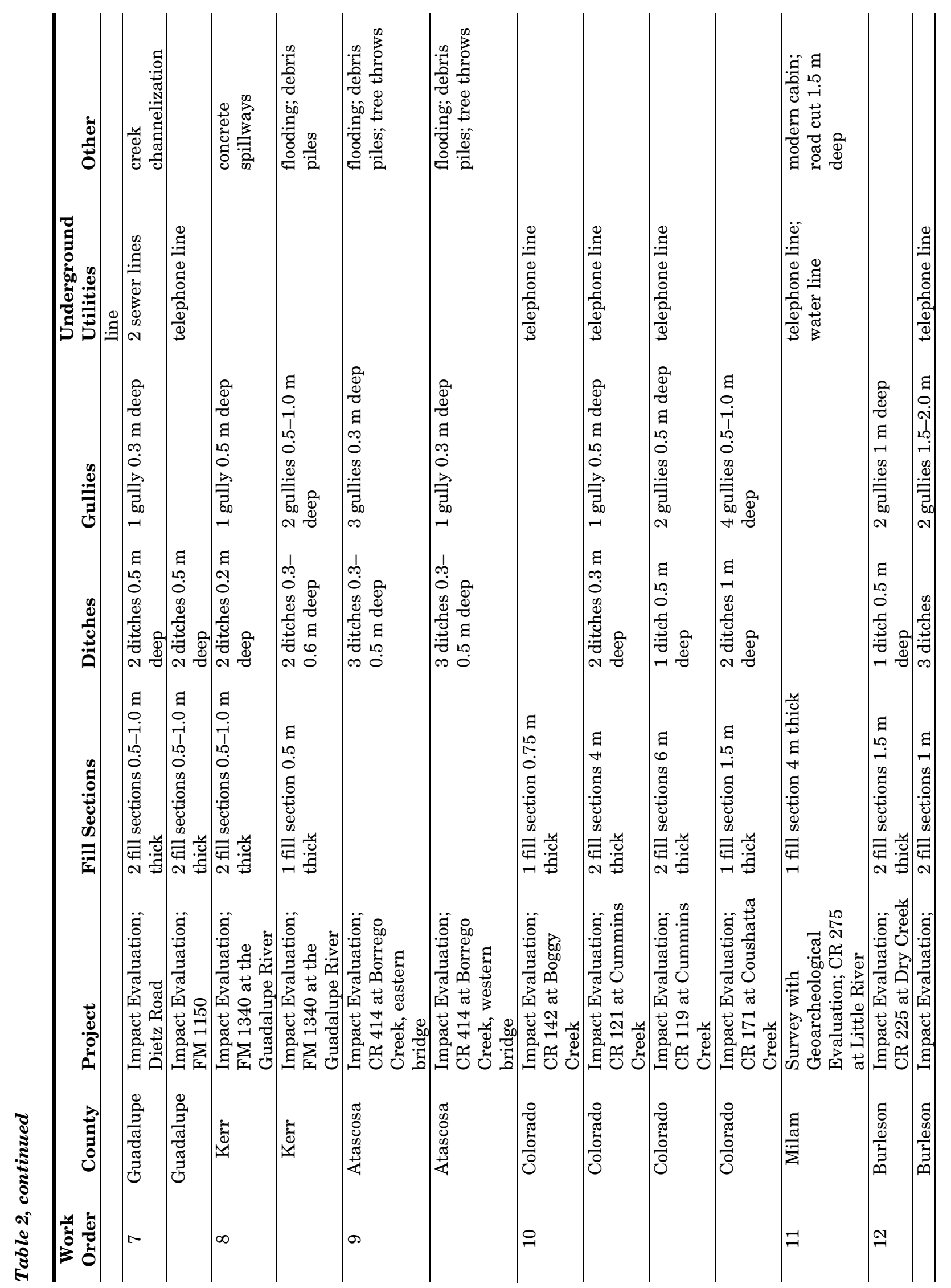




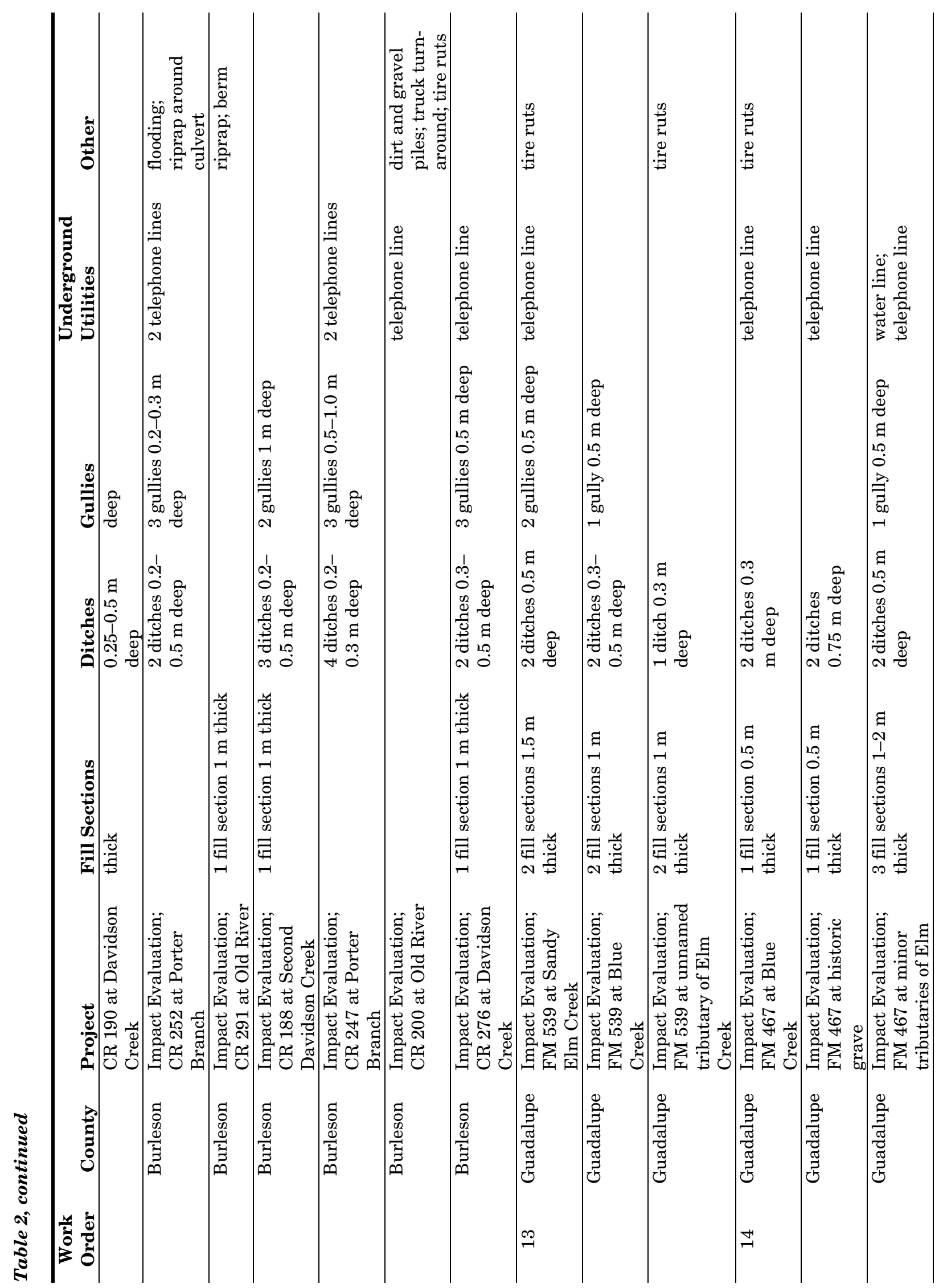




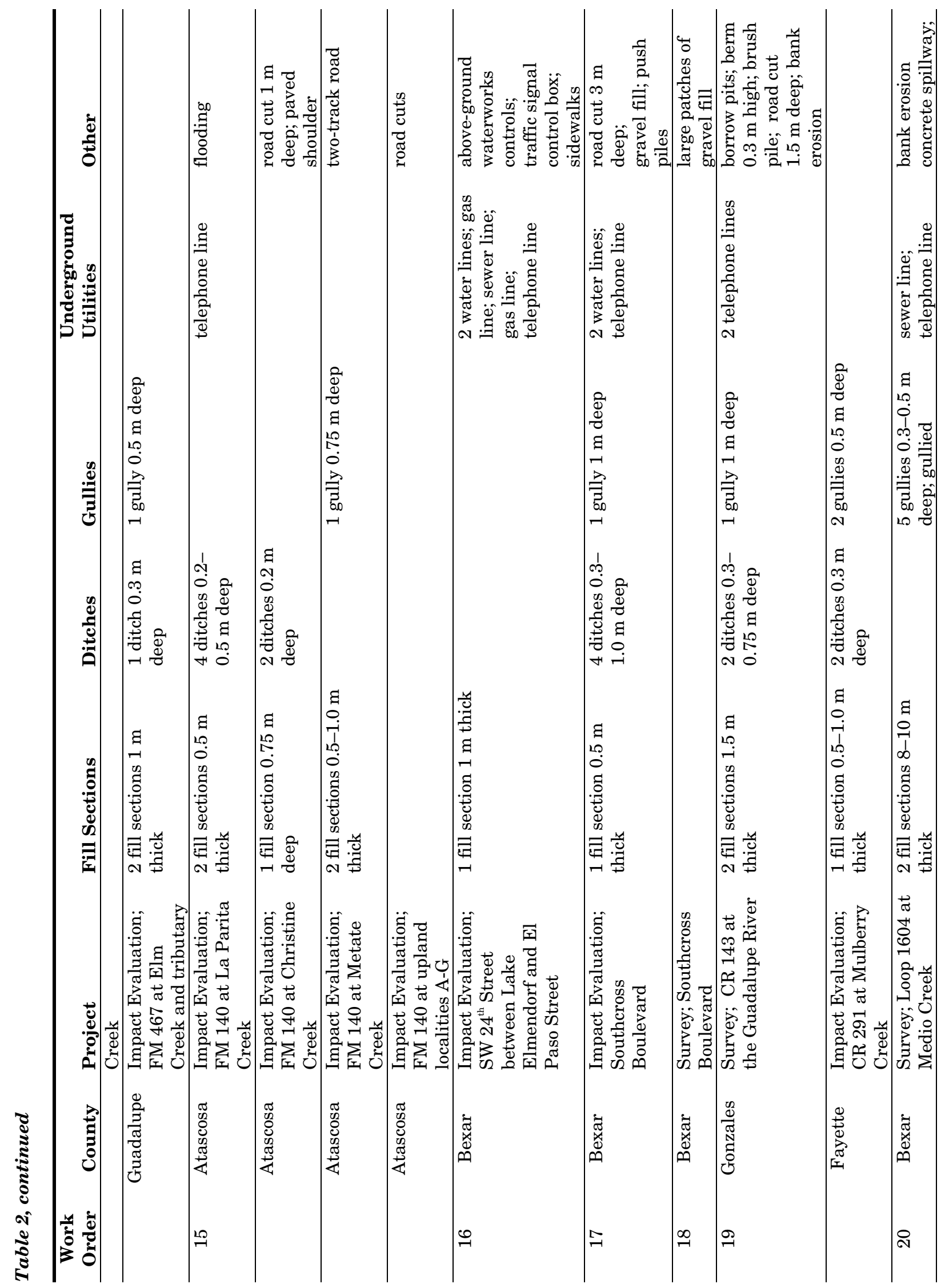




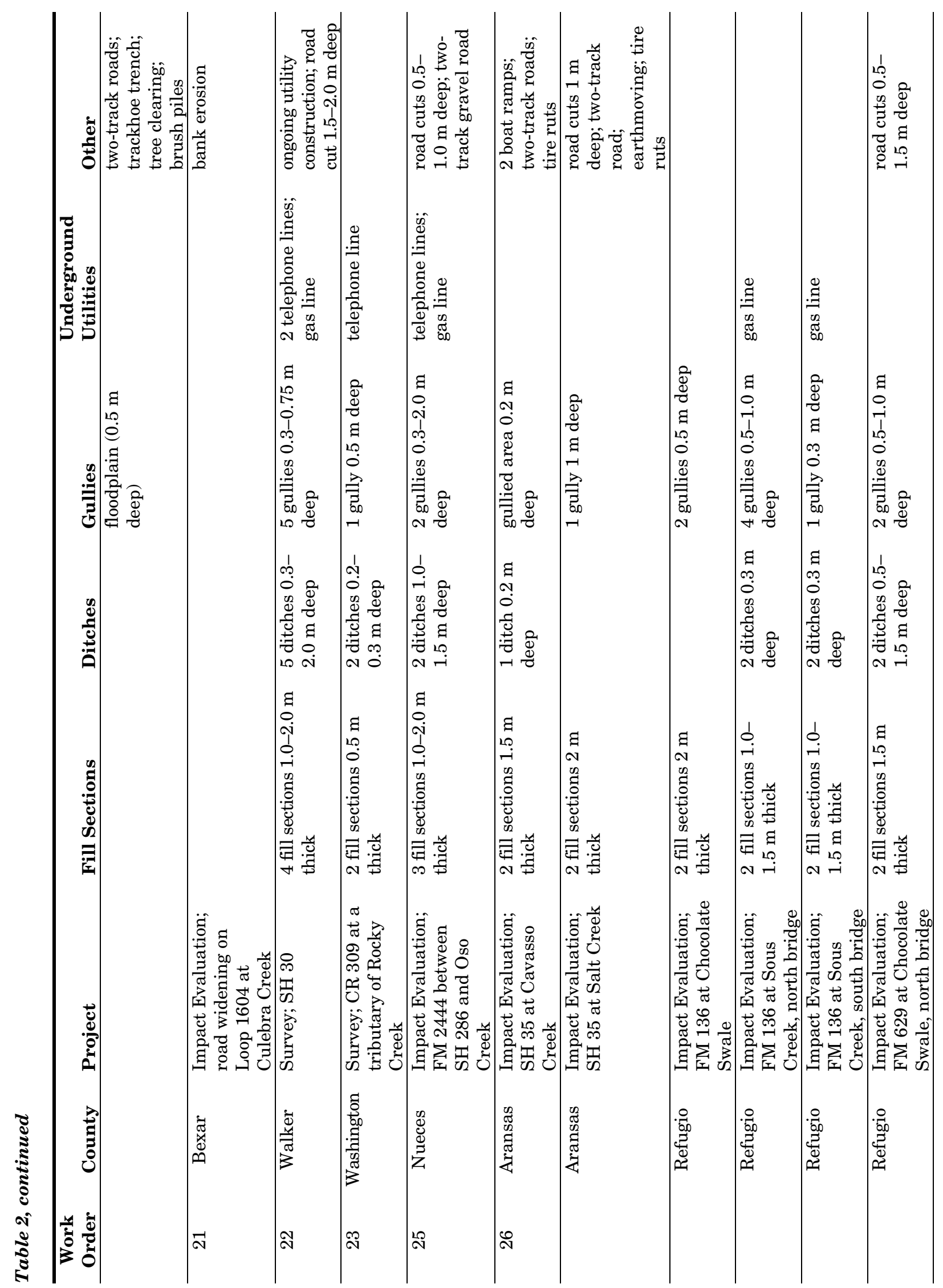




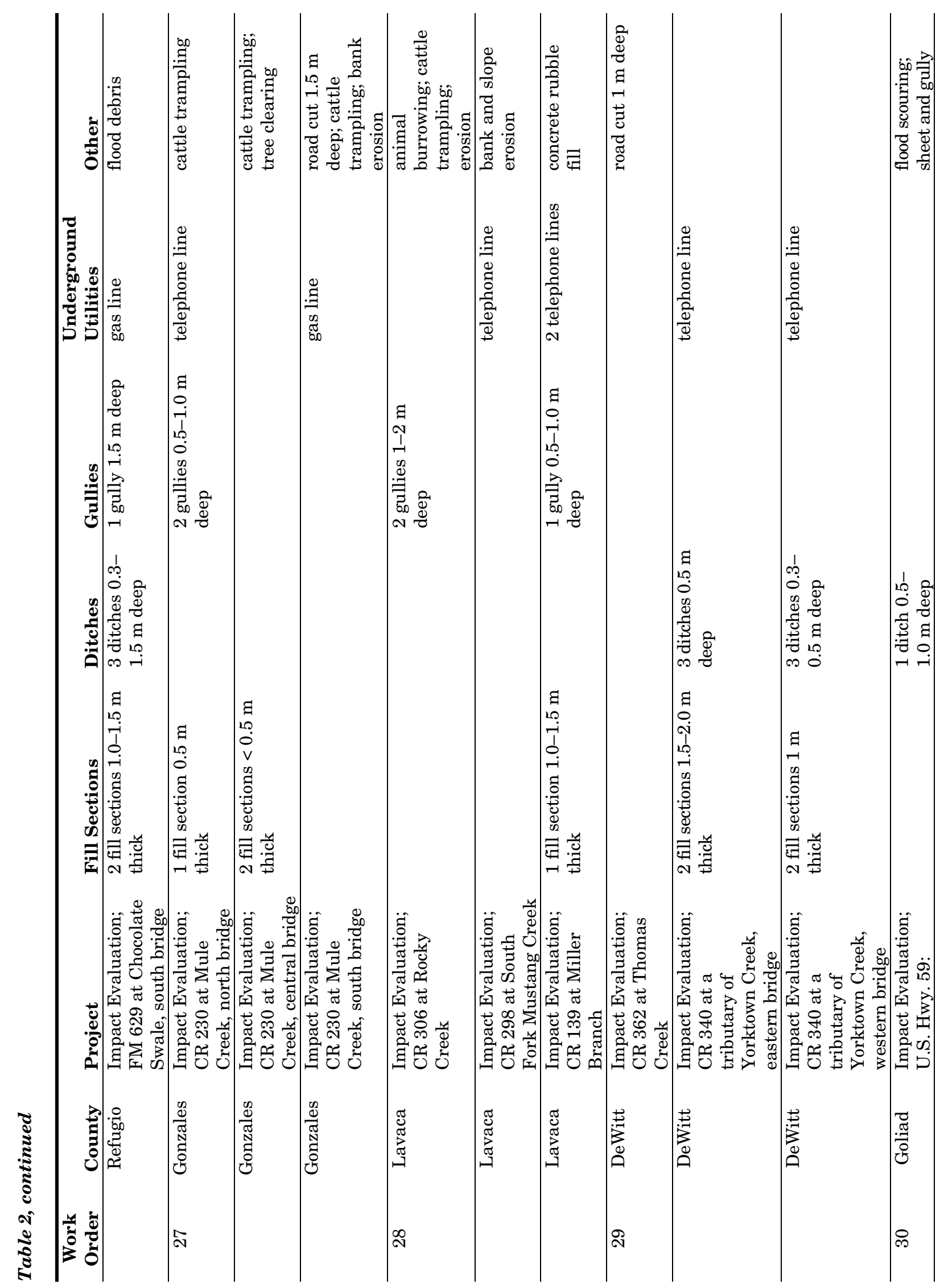




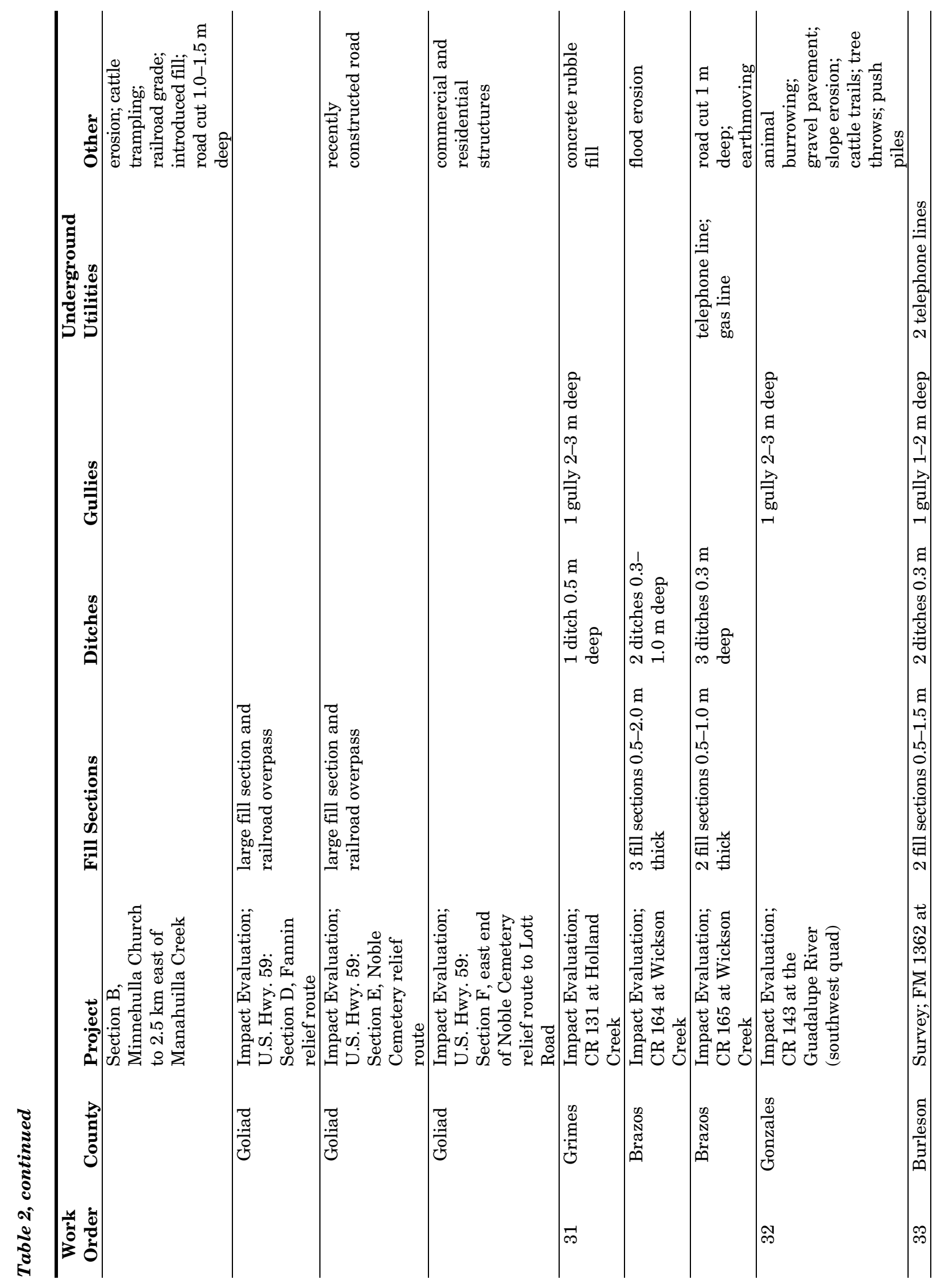




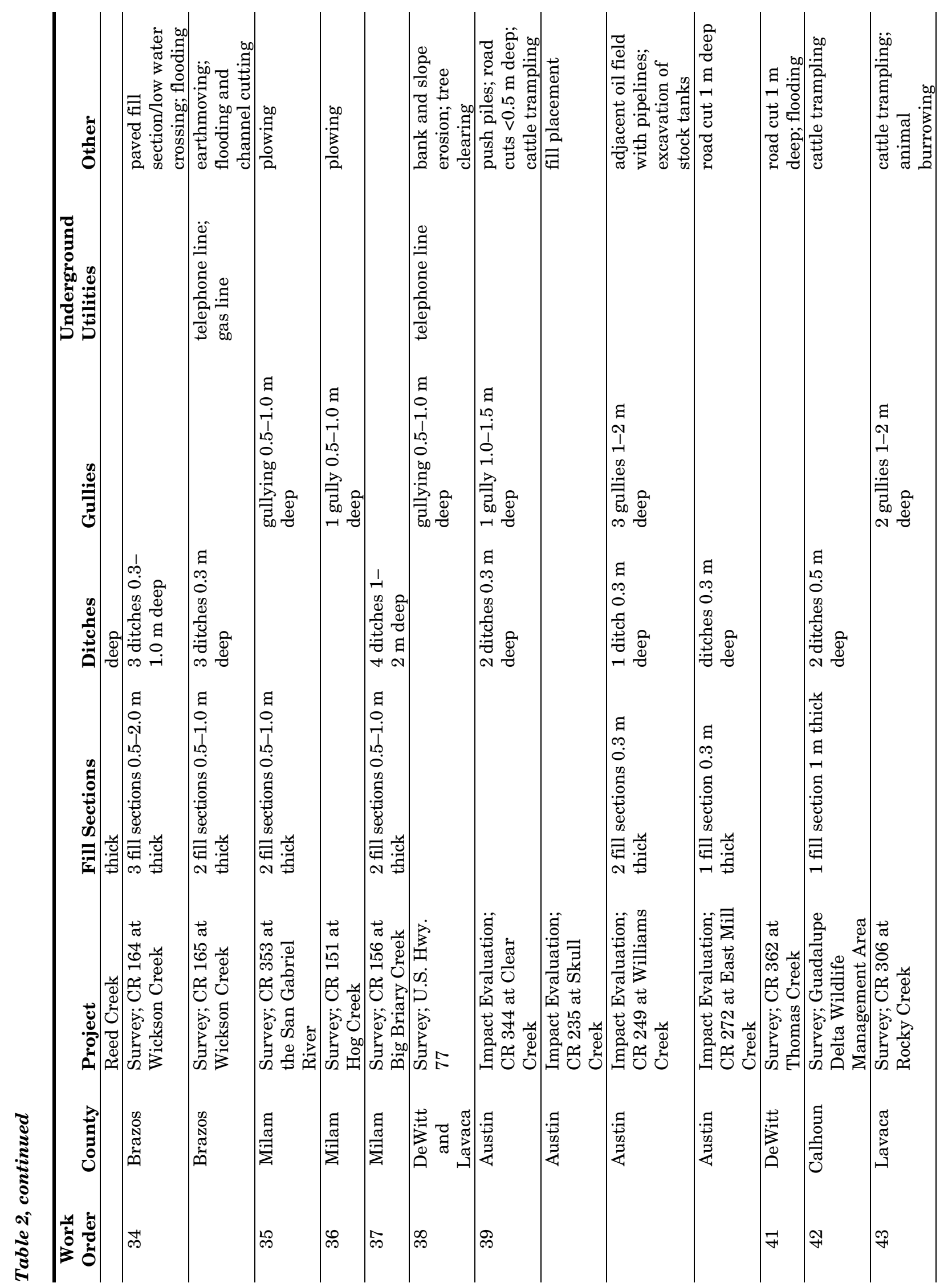




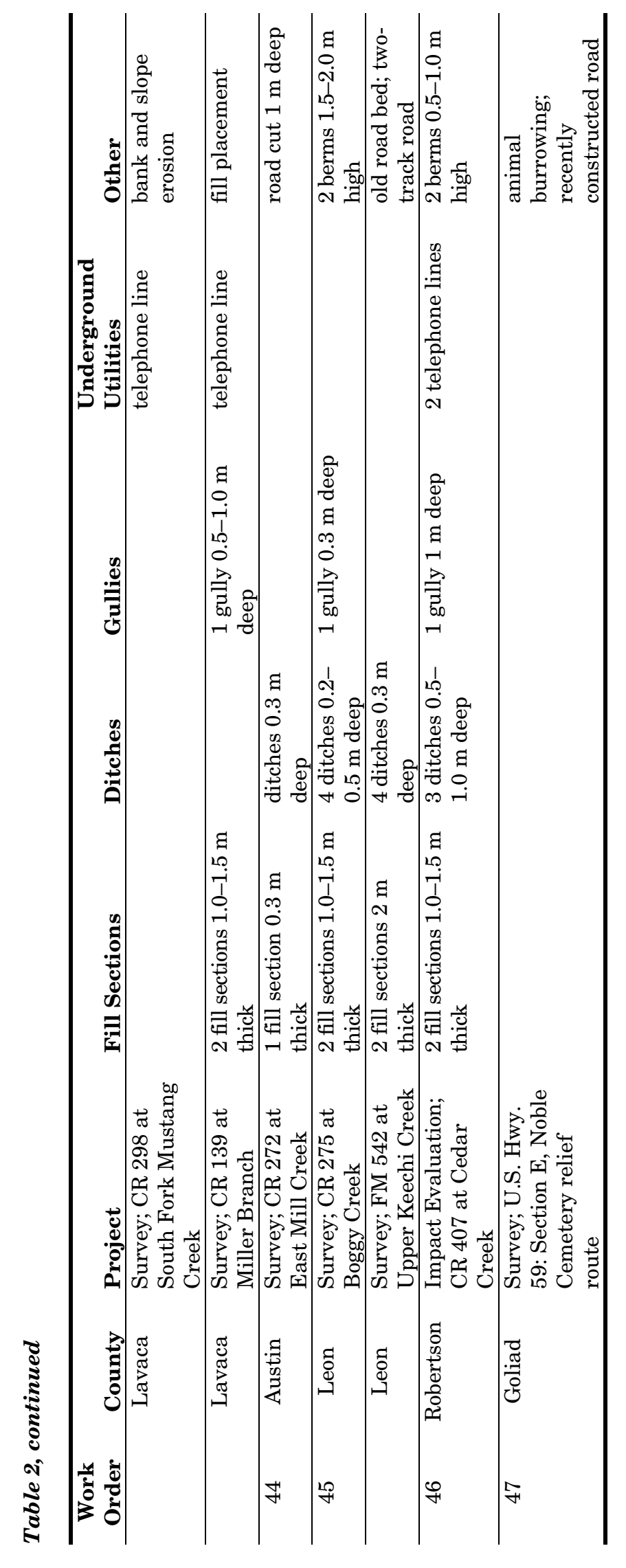


Table 3. Summary of archeological sites investigated

\begin{tabular}{clll}
\hline $\begin{array}{c}\text { Work } \\
\text { Order }\end{array}$ & Site & Materials Observed & Recommendation \\
\hline 20 & $41 \mathrm{BX} 1421$ & $\begin{array}{l}\text { biface, debitage, modified flakes, cores, tested } \\
\text { cobbles, burned rocks, animal bones, mussel } \\
\text { shell }\end{array}$ & test excavations \\
\hline 35 & $41 \mathrm{MM} 373$ & $\begin{array}{l}\text { biface, debitage, core, burned rock feature, } \\
\text { burned rocks, mussel shells, Rabdotus shells }\end{array}$ & test excavations \\
\hline 38 & $41 \mathrm{LC} 13$ & none & $\begin{array}{l}\text { apparently destroyed; no } \\
\text { further work }\end{array}$ \\
\hline 47 & $41 \mathrm{GD} 113$ & $\begin{array}{l}\text { biface, debitage, animal bones, mussel shells, } \\
\text { Rabdotus shells }\end{array}$ & test excavations \\
\hline & & biface, debitage, animal bones & test excavations \\
\hline
\end{tabular}

observed on the surface; no temporally diagnostic artifacts were noted. All of the worked lithics appeared to be Edwards chert. Burned rocks also were observed on the surface, as well as buried up to $97 \mathrm{~cm}$ in the $\mathrm{T}_{2}$ alluvium exposed in a trackhoe trench associated with sewer line construction. Burned rocks, burned bones, and lithics also were observed eroding out of the beveled $\mathrm{T}_{2}$ terrace edge along the tributary cutbank $30 \mathrm{~m}$ south of Medio Creek.

A backhoe trench was placed within the site in the new right of way. A burned rock was observed in the wall at $66 \mathrm{~cm}$, and burned rocks and lithics were noted on the backdirt pile. Two stratigraphic units were observed consisting of fluvial cobbles and pebbles overlain by finegrained sediments. The $\mathrm{T}_{2}$ sediments exhibit a relatively weak soil profile consisting of the following: a 44-cm-thick A horizon consisting of very friable very dark gray (10YR 3/1) silty clay loam with weak medium subangular blocky structure and an abrupt smooth boundary; a 44-cm-thick Bw horizon consisting of dark yellowish brown (10YR 4/4) clay loam with weak coarse subangular blocky structure, many (20 percent) fine irregular carbonate filaments, and an abrupt wavy boundary; and a $2 \mathrm{C}$ horizon consisting of subrounded fluvial pebbles and cobbles in a clay loam matrix at $88+\mathrm{cm}$.

Two shovel tests were placed within the site in the channel easement. One test yielded 20 flakes and 1 bone fragment from $0-20 \mathrm{~cm}$ and 12 flakes and 1 mussel shell fragment from 20 $40 \mathrm{~cm}$. The second test yielded 1 flake from the upper $20 \mathrm{~cm}$ and 3 flakes from $20-40 \mathrm{~cm}$.
Within the proposed channel easement and adjoining new right of way west of Loop 1604, 41BX1421 contains archeological materials in good context. Located on the $\mathrm{T}_{2}$ terrace of Medio Creek, the site encompasses up to $1 \mathrm{~m}$ of finegrained Holocene alluvium with documented subsurface archeological remains. Despite disturbance from recent construction activities, it is estimated that at least 50 percent of 41BX1421 remains intact. Based on the presence of intact subsurface deposits and the high probability of intact cultural features, the site is considered potentially eligible for listing in the National Register of Historic Places and designation as a State Archeological Landmark, pending testing to more fully determine the content, age, and integrity of the buried cultural components.

\section{Work Order 35, $41 M M 373$}

In the northern portion of the CR 353 at the San Gabriel River project area in Milam County, five backhoe trenches were excavated with cultural materials noted in all but one trench. Trench 4 was located east of CR 353 and exposed a $50-\mathrm{cm}$-thick very dark brown (10YR 2/2) silty clay loam A horizon overlying $130 \mathrm{~cm}$ of mottled brown (10YR 5/3) and pale brown (10YR 6/3) silt loam. A possible burned rock and crushed Rabdotus snails were noted at and above the contact of the two soil horizons, but no diagnostic cultural materials were observed. Trench 5 was located on the west side of CR 353 and exhibited a similar profile to Trench 4, 
with cultural materials noted in the upper A horizon and a small burned rock feature and scattered burned rocks in the lower soil horizon at $135 \mathrm{~cm}$. Trench 6 exhibited a similar profile to Trench 5 , with a single piece of burned chert noted at $110 \mathrm{~cm}$. Trenches 7 and 8 , both close to the river, exhibited slightly thicker A horizons $(70 \mathrm{~cm})$. A few pieces of chert debitage and a mussel shell were noted at depths of 120 to $140 \mathrm{~cm}$.

The archeological remains observed in Trenches 5-8 were recorded as 41MM373. The site apparently consists of at least two segregated cultural components. The first consists of several pieces of burned rock, lithic debitage, a chert core, a chert biface fragment, and mussel shells contained within the upper A horizon ( 0 $50 \mathrm{~cm}$ ) in Trench 5 . These materials were noted in the wall of the trench during profiling and in the backdirt during monitoring. No diagnostic artifacts were encountered. The second component is contained within the weakly developed subsoil from 110 to $140 \mathrm{~cm}$ and is represented by a small burned rock feature, two flakes, mussel shells, and two pieces of burned chert. The burned rock feature was exposed in Trench 5 at $135 \mathrm{~cm}$. Trenching was halted when the feature was exposed on the trench floor. The feature measured $45 \times 25 \mathrm{~cm}$ and was between 15 and $20 \mathrm{~cm}$ thick. It consisted of many pieces of small, angular burned rocks with no apparent pattern other than being contained within the charcoal-stained area. A considerable amount of charcoal was noted within the feature but not collected. Scattered burned rocks also were noted on the trench floor ca. $1 \mathrm{~m}$ from the feature. Other cultural materials occurred at approximately the same elevation in other trenches, including a burned chert fragment in the wall of Trench 6 at $120 \mathrm{~cm}$, a mussel shell and two flakes in Trench 7 at 120 to $130 \mathrm{~cm}$, and a piece of burned chert in Trench 8 at $140 \mathrm{~cm}$. No temporally diagnostic artifacts were encountered, hence the ages of these materials are unknown. The site appears to be within the entire northern right of way and likely extends beyond the western and possibly eastern boundary of the northern project area.

The site is buried within fine-grained alluvial sediments and appears to have at least two cultural components with at least one demonstrating good contextual integrity based on the buried burned rock feature. As a result, the site could yield important archeological information and is considered potentially eligible for listing in the National Register of Historic Places and designation as a State Archeological Landmark, pending test excavations to determine more fully the content, age, and integrity of the cultural components.

\section{Work Order 38, 41LC13}

One previously recorded site-41LC13-is reported in the existing right of way on the $\mathrm{T}_{2}$ terrace and upland south of Little Brushy Creek in the U.S. Highway 77 widening project area in Lavaca County. Initially recorded by G. R. Dennis Price (TxDOT) in 1994, the site was observed eroding out of a $1.5-\mathrm{m}$-high and $20-\mathrm{m}$ long road cut east of the road. Price dug four negative shovel tests in the graded road by the cut and one in the road cut. According to records at the Texas Archeological Research Laboratory, the test in the road cut did not produce diagnostic artifacts but did contain "thermally fractured chert, one apparent pebble-gouge, a few good flakes, and a few small fragments of mussel shell." Price also noted what appeared to be noncultural Rabdotus shells associated with these materials. He also observed a "possible hearth or burn area" that included "black sandstone" (but no charcoal) resting on decomposing bedrock between 35 and $60 \mathrm{~cm}$ in the road cut. Based on the one positive shovel test and the possible feature, he considered the site potentially eligible for listing in the National Register of Historic Places and designation as a State Archeological Landmark.

Under Work Order 38, the area of 41LC13 was subjected to careful pedestrian examination. Because visibility in the road cut was good (50 percent) and no artifacts or archeological features were observed, no shovel tests were dug. The $\mathrm{T}_{2}$ terrace and upland surface immediately east of the site also were examined (2550 percent visibility), but no archeological materials were observed. A backhoe trench was excavated in this area ca. $15 \mathrm{~m}$ east of the reported site location, but no archeological materials were encountered. Excavated to a depth of $1.0 \mathrm{~m}$, the trench revealed A-Bk1-Bk2-Cr horizons. The A horizon $(0-20 \mathrm{~cm})$ is very dark grayish brown (10YR 3/2) sandy clay loam. The Bk1 horizon $(20-41 \mathrm{~cm})$ is dark yellowish brown (10YR 4/4) silty clay with coarse irregular soft 
carbonate masses. The Bk2 horizon (41-95 cm) is very pale brown (10YR 8/2) silty clay, contains abundant caliche, and is entirely whitened in some areas. The Cr horizon $(89-95+\mathrm{cm})$ is brown (10YR 5/5) clay mottled yellowish red (5YR 5/6). Because no archeological remains were observed, 41LC13 could not be re-located. It appears that the site may have been limited to the existing right of way and has been destroyed by erosion. Thus, it is considered ineligible for listing in the National Register of Historic Places or designation as a State Archeological Landmark.

\section{Work Order 47, 41GD113 and $41 G D 114$}

In February 2001, avocational archeologist Smitty Schmiedlin provided (through Texas Historical Commission archeologist Mike Davis) preliminary documentation (but not trinomial designations) on 41GD113 and 41GD114 recorded under Work Order 47 for survey of the Noble Cemetery relief route along U.S. Highway 59 in Goliad County. Both sites are low rises into which the landowner reportedly had made small bulldozer cuts. In these cuts, Schmiedlin observed bone fragments, mussel shells, lithics, and charcoal. These sites were examined but not recorded during the June 2001 Impact Evaluation done under Work Order 30.

Site 41GD113 is the western rise. It is located in a pasture ca. $125 \mathrm{~m}$ north of the upper reach of Payton Branch and $150 \mathrm{~m}$ north of the present location of U.S. Highway 59. The rise measures $30 \times 30 \mathrm{~m}$ and stands about $75 \mathrm{~cm}$ high on the upland edge. A thicket of mesquite trees and thick forbs marks the site. This vegetation is distinctive because short-grass pasture surrounds the site. A private road through the pasture cuts the northern end of the site and has destroyed approximately 30 percent of 41GD113. Lithic flakes, one biface fragment, Rabdotus shells, and mussel shell fragments were noted in the drainage ditch along the south side of the road. Otherwise, the site appears intact.

Five shovel tests were dug to $100 \mathrm{~cm}$, and the sixth reached a depth of $80 \mathrm{~cm}$. The tests revealed relatively deep soils on the rise consisting of 60-90 cm of dark gray sandy clay loam above a grayish brown clay loam. Five of the six shovel tests on the site produced 27 pieces of lithic debitage, 2 burned chert fragments, 2 mussel shell umbo fragments, and 4 small pieces of animal bone. Two of the bone fragments appear to be bits of turtle carapace, and the other 2 are unidentifiable. Rabdotus shells and flecks of mussel shells were noted throughout the deposit, with the two umbo fragments coming from $40-60 \mathrm{~cm}$ below the surface in Shovel Tests 3 and 4. Lithic debitage and bone flecks also occur throughout the deposit, with almost half of the debitage (13 flakes) and all of the larger bones coming from Levels 4 and $5(60-100 \mathrm{~cm})$ in Shovel Tests 3-5. Levels $1(0-20 \mathrm{~cm}), 2(20-40 \mathrm{~cm})$, and $3(40-60 \mathrm{~cm})$ in Shovel Tests $1-5$ produced 4 flakes, 6 flakes, and 4 flakes.

Site 41GD114 is located approximately $100 \mathrm{~m}$ east of 41GD113 on the same landform. The site also is on a small rise, approximately $75 \mathrm{~cm}$ in height, that is $30 \mathrm{~m}$ north of Payton Branch and $160 \mathrm{~m}$ north of the present location of U.S. Highway 59 . The rise is ca. $25 \times 30 \mathrm{~m}$ and is marked by a mesquite thicket and tall forbs resembling those found at 41GD113. This site, however, does not appear to have been disturbed recently, and it is estimated that nearly 100 percent remains intact. No sign of the landowner's bulldozer cut Schmiedlin reported was observed.

As at 41GD113, the sediments at 41GD114 are deeper than they are on the surrounding upland surface. They are composed of $40-100 \mathrm{~cm}$ of dark gray sandy clay loam. In Shovel Tests 2 , 4 , and 5 , dark gray clay loam with few to many siliceous gravels underlies the sandy clay loam at $40-60 \mathrm{~cm}$. These three shovel tests were located on the western edge of the rise; none of them produced cultural materials. Only Shovel Tests 1 and 6 produced materials on this rise. These tests were located on the central, highest part of the rise. The materials recovered came from $60-100 \mathrm{~cm}$ below the surface in both tests, with Levels $4(60-80 \mathrm{~cm})$ and $5(80$ $100 \mathrm{~cm}$ ) each yielding four items. The materials recovered from 41GD114 consist of five lithic flakes, one distal end of a biface, and two small bone fragments, one of which appears to be a piece of a turtle carapace. Missing at this site are the Rabdotus and mussel shell fragments observed throughout the deposit at 41GD113. Rabdotus shells are present at 41GD114, but they appear to be concentrated at the surface in the vicinity of Shovel Test 1 and thus may not be cultural.

In terms of landform, soils, vegetation, and 
the kinds of artifacts present, 41GD113 and 41GD114 appear similar. Site 41GD114 produced fewer artifacts and may have not have seen the same intensity of occupation as 41GD113. Both sites, however, appear to have buried cultural deposits. Though sparse, faunal remains are present. These results suggest that both sites may represent small, possibly special-purpose camps located on the edge of an upland drainage.

The processes by which such upland rises form remain obscure (see Abbott [2001:91-97] for a discussion of the archeological significance of apparently similar landforms in the Houston area), but the possibility that they are depositional features indicates that they may contain archeological remains in good context. Based on this possibility and the remains found in the shovel tests, both 41GD113 and 41GD114 are considered potentially eligible for listing in the National Register of Historic Places and designation as State Archeological Landmarks, pending test excavations and geomorphic investigations to more fully determine the content, age, and integrity of the cultural deposits.

\section{Patterns in Site Distributions}

With a sample of just five prehistoric sites (one of which apparently has been destroyed), it is difficult to draw conclusions about patterns in site distributions and associations between site locations and elements of the environment. Nonetheless, it is useful to note that the investigated sites were in a variety of topographic settings near water courses, including a $\mathrm{T}_{2}$ terrace and upland margin, low rises on Pleistocene uplands, a floodplain with relatively thin alluvium in the Balcones Canyonlands, and a floodplain with thicker alluvium on the Blackland Prairie. Two of the sites are in the Corpus Christi District, and one each is in the Bryan, San Antonio, and Yoakum Districts.

The two Corpus Christi District sites (41GD113 and 41GD114) occupy low circular rises on the Pleistocene Lissie Formation overlooking the Payton Branch arm of Coleto Creek Reservoir. These rises appear to be depositional settings and probably are comparable to pimple mounds documented elsewhere on the coastal plain. The cultural deposits at these sites extend to a depth of $100 \mathrm{~cm}$. The single Bryan District site (41MM373) is buried within allu- vium along the San Gabriel River, a short distance upstream from where it joins Brushy Creek. Cultural materials appear to be concentrated at $0-50$ and $110-140 \mathrm{~cm}$; deeper archeological remains could be present as well because the trenches did not extend below $140 \mathrm{~cm}$. The single San Antonio District site (41BX1421) is buried in thinner fine-grained alluvium (90$100 \mathrm{~cm}$ ) atop fluvial pebbles and cobbles along Medio Creek. The single Yoakum District site (41LC13), which apparently has been destroyed, occupied a $\mathrm{T}_{2}$ terrace and upland overlooking Little Brushy Creek. The depth of the cultural deposits is not certain, but they appear to have been restricted to the upper $35-60 \mathrm{~cm}$.

\section{Utility of Existing Methods}

In general, the methods employed for Impact Evaluations and Surveys appear to be consistent with a "reasonable and good faith effort" to comply with federal and state laws governing identification of archeological sites that are eligible for listing in the National Register of Historic Places or designation as State Archeological Landmarks. The level of effort typically required to complete an Impact Evaluation (12 hours for a single bridge replacement) seems appropriate given the intent of this type of work and the generally small project areas. When Impact Evaluations can quickly separate those project areas where survey is truly a good idea from those where sites are very unlikely or almost surely disturbed, they are an efficient and relatively inexpensive measure to guard against the loss of important archeological data.

The levels of effort spent on Surveys and the amounts of work done (i.e., numbers of trenches and shovel tests) also seem appropriate given the sizes of the project areas, although the amount of work can vary based on a variety of factors other than project size (e.g., backhoe accessibility, depth to ground water, landowner permission to trench, extent of disturbance, and number and location of buried utilities that must be avoided during trenching). The work done on these surveys easily meets or exceeds the Texas Historical Commission's archeological survey standards, except in some cases where only trenches were dug. This was the case in some floodplain settings where shovel testing was considered ineffective and inefficient because of the thickness 
of the alluvium or because of dense clay soils. In these cases, the much greater subsurface visibility afforded by the backhoe trenches and the fact that the number of trenches well exceeds the minimum required compensates for the lack of shovel testing.

\section{Evaluation of the Need for Survey}

This final section deals with the related topics of identifying patterns of existing disturbances that affect the need for survey and predicting when field inspections are and are not needed. Based on the work done during this project, these issues can be addressed best by looking at how often survey was deemed warranted when an Impact Evaluation was completed and the factors that contributed to these evaluations. ${ }^{1}$

Of the 71 Impact Evaluations done, 15 led to recommendations that survey was needed before construction, and 56 resulted in recommendations for no survey. All but 2 of those where survey was recommended involved acquisition of new right of way and thus disturbance of areas that previous road construction had not affected. Of the 56 Impact Evaluations in which survey was not recommended, 20 involved new right of way and 36 did not. Breaking these figures down by the type of Transportation Activity and the kind of road shows some interesting patterns.

Two kinds of Transportation Activitiesbridge replacements and road widening projects-and several kinds of roadwayscounty roads, farm-to-market roads, state highways, U.S. highways, and roads in urban areas-are represented in the sample. Of the 38 Impact Evaluations for bridge replacements on county roads, 24 involved new right of way and 14 did not. Of the 24 with new right of way, 11 were considered to warrant survey. On average, these areas of new right of way were no larger (range $=0.08-0.9$ acres; mean $=0.35$ acres) than those on the 13 bridge replacements where survey was not recommended (range $=0.06-1.9$ acres; mean $=0.33$ acres $)$, and thus right of way size did not determine when survey was recommended (although this could have been a factor in some areas with very limited new right of way). Rather, the presence of significant amounts of disturbance, along with the presence of thin allu- vium in some cases, made survey unnecessary.

Of the 14 bridge replacement projects without new right of way on county roads, only 2 were judged to need survey. One of these (Work Order 31, bridge replacement on CR 164 at Wickson Creek) had up to $6 \mathrm{~m}$ of undisturbed existing right of way with Holocene alluvium and the potential for buried archeological remains. The other (Work Order 39, bridge replacement on CR 272 at East Mill Creek) contained less undisturbed existing right of way, but the project area extended onto a terrace or upland knoll where archeological remains were considered likely.

These data show that the presence of new right of way is a partial indicator of where survey is needed in these kinds of projects (i.e., bridge replacements on county roads). The roadways are small, sometimes have relatively limited disturbance within the existing right of way, and generally are in rural areas where adjacent lands are undeveloped and often (but not always) little disturbed. As Work Orders 31 and 39 indicate, however, new right of way is not a perfect indicator of where survey is warranted. This, and the inability to predetermine where significant existing disturbances and thin alluvium might exist in project areas with new right of way, suggest that Impact Evaluations will continue to be the prudent choice on almost all such projects, whether new right of way is involved or not.

Fewer projects involving bridge replacements on larger roads (farm-to-market roads and state highways) were completed-all nine cases involved no new right of way. Larger roads usually have wider rights of way than county roads and thus may have a greater potential to contain archeological sites, but they also tend to be more highly disturbed, which explains why no survey was recommended in any of these

\footnotetext{
${ }^{1}$ A more thorough evaluation of these issues looking at a larger number of projects over a broader geographic area might be instructive and probably could be done best by TxDOT using data from projects done by in-house personnel and contractors. It would be interesting to look at projects in which Impact Evaluations were followed by Surveys (and the rationales for requiring Surveys) and whether the additional work resulted in the discovery of potentially important sites.
} 
nine projects. Two of these (Work Orders 8 and 9 ) were in the western part of the study area where relatively thin gravelly alluvium was documented within disturbed rights of way. The other seven (Work Order 26) were near the coast in Refugio County where extensive fill sections associated with ditches and gullies are common. This sample is too small and too slanted to particular settings to make general statements about the need for survey on such projects.

Impact Evaluations were done for roadwidening projects in urban areas, on farm-tomarket roads, and on a U.S. highway. Of the five projects in urban settings, four involved new right of way and one did not. Only one project, which involved 5.2 acres of new right of way, was considered to warrant survey. Survey was unnecessary in the other areas because of disturbance related to development of adjoining lands. This pattern is likely to pertain generally to projects in urban areas but is not a good basis for concluding that survey is not warranted in all such areas, at least where new right of way is involved.

Of the 15 Impact Evaluations on projects involving widening of farm-to-market roads (six roads total, with multiple Impact Evaluations on three roads), only 1 involved new right of way. Survey was not recommended in any of these 15 areas. In 7 cases, this was because of the lack of appreciable Holocene deposits that could host archeological remains in good context coupled with the presence of moderate to extensive disturbance. Seven other areas, including the one with new right of way, had thicker alluvium but sufficient disturbance to argue against survey. In one case, the Impact Evaluation was done because of a marked grave just outside the existing right of way; no evidence was found to indicate that that grave or any others extended into the project area. Because farm-to-market roads can have rights of way of variable width and exhibiting varying degrees of disturbance, the results of these 15 Impact Evaluations are not sufficient to conclude that surveys generally are not warranted on such projects.

Finally, four Impact Evaluations were done along sections of U.S. Highway 59 in Goliad County where the highway will be widened and, in two places, rerouted to avoid a town and a cemetery. New right of way will be acquired in all four cases, but survey was recommended in only one area. This area, although in a largely upland setting, flanked an arm of Coleto Creek Reservoir and was known to contain sites. Two of the other areas did not warrant survey because they consisted of flat expanses of Pleistocene coastal plain where sites are unlikely. Survey was not recommended for the fourth area because the new right of way extended only a few meters beyond a heavily disturbed railroad grade and contained limited Holocene alluvial deposits. As for most of the other categories of projects, this sample is too small and too skewed to allow general statements about the need for survey on comparable future projects, except that large projects such as this one obviously require careful, case-by-case consideration. 
THIS PAGE INTENTIONALLY LEFT BLANK 


\section{REFERENCES CITED}

Abbott, James T.

2001 Houston Area Geoarcheology: A Framework for Archeological Investigation, Interpretation, and Cultural Resource Management in Houston Highway District. Archeological Studies Program, Report 27. Texas Department of Transportation, Environmental Affairs Division, Austin.

Aronow, S., W. L. Fisher, J. H. McGowen, and V. E. Barnes

1982 Geologic Atlas of Texas, Houston Sheet. Bureau of Economic Geology, The University of Texas at Austin.

Aten, Lawrence E.

1983 Indians of the Upper Texas Coast. Academic Press, New York.

Barnes, V. E., and P. R. Rose

1981 Geologic Atlas of Texas, Llano Sheet. Bureau of Economic Geology, The University of Texas at Austin.

Bement, Leland C., Wayne Bartholomew, Glenn T. Goode, Stephen A. Hall, and David G. Robinson

1989 Excavations at 41BP19, The Kennedy Bluffs Site, Bastrop County, Texas. Contract Reports in Archaeology, Report Number 5. Texas State Department of Highways and Public Transportation, Highway Design Division, Austin.

Birmingham, W. W., and Thomas Hester

1976 Late Pleistocene Archaeological Remains from the Johnson-Heller Site, Texas Coastal Plain. In Papers on Paleo-Indian Archeology in Texas: 1, pp. 15-33. Special Report No. 3. Center for Archaeological Research, The University of Texas at San Antonio.

Black, Stephen L.

1986 The Clemente and Herminia Hinojosa Site, 41JW8: A Toyah Horizon Campsite in Southern Texas. Special Report No. 18. Center for Archaeological Research, The University of Texas at San Antonio. 1989a South Texas Plains. In From the Gulf to the Rio Grande: Human Adaptation in Central, South, and Lower Pecos Texas, by Thomas R. Hester, Stephen L. Black, D. Gentry Steele, Ben W. Olive, Anne A. Fox, Karl J. Reinhard, and Leland C. Bement, pp. 39-62. Research Series No. 33. Arkansas Archeological Survey, Fayetteville.

1989b Central Texas Plateau Prairie. In From the Gulf to the Rio Grande: Human Adaptation in Central, South, and Lower Pecos, Texas, by Thomas R. Hester, Stephen L. Black, D. Gentry Steele, Ben W. Olive, Anne A. Fox, Karl J. Reinhard, and Leland C. Bement, pp. 17-38. Research Series No. 33. Arkansas Archeological Survey, Fayetteville.

Black, Stephen L., and Wayne L. Cox

1983 A Cultural Resource Survey of Dredge Disposal Sites Along the Gulf Intracoastal Waterway, Brazoria and Matagorda Counties, Texas. Archaeological Survey Report No. 124. Center for Archaeological Research, The University of Texas at San Antonio.

Black, Stephen L., Linda W. Ellis, Darrell G. Creel, and Glenn T. Goode

1997 Hot Rock Cooking on the Greater Edwards Plateau: Four Burned Rock Midden Sites in West Central Texas, Volumes 1 and 2. Studies in Archeology 22. Texas Archeological Research Laboratory, The University of Texas at Austin. Archeology Studies Program, Report 2. Environmental Affairs Department, Texas Department of Transportation, Austin.

Black, Stephen L., and A. Joachim McGraw

1985 The Panther Springs Creek Site: Cultural Change and Continuity within the Upper Salado Creek Watershed, South-Central Texas. Archeological Survey Report No. 100. Center for Archaeological Research, The University of Texas at San Antonio.

Bolton, Herbert Eugene

1970 Texas in the Middle Eighteenth Century: 
Studies in Spanish Colonial History and Administration. The Texas State Historical Association and the University of Texas Press, Austin.

Bousman, C. Britt

1998 Paleoenvironmental Change in Central Texas: The Palynological Evidence. Plains Anthropologist 43(164):201-219.

Bowman, Bradley F.

1985 Winnie's Mound (41BU17): A Study in the Prehistory of Burleson County, Texas. Bulletin of the Texas Archeological Society 56:39-74.

Brown, David O.

1983 The Berger Bluff Site (41GD30A): Excavations in the Upper Deposits, 1979. Archaeological Survey Report No. 115. Center for Archaeological Research, The University of Texas at San Antonio.

Brown, Kenneth M.

1996 Berger Bluff. In The New Handbook of Texas, Vol. 1:497-498. The Texas State Historical Association, Austin.

Brown, L. F., Jr., J. L. Brewton, and J. H. McGowen 1975 Geologic Atlas of Texas, Corpus Christi Sheet. Bureau of Economic Geology, The University of Texas at Austin.

Brown, T. E., J. L. Brewton, J. H. McGowen, C. V. Proctor, S. Aronow, and V. E. Barnes

1987 Geologic Atlas of Texas, Beeville-Bay City Sheet. Bureau of Economic Geology, The University of Texas at Austin.

Brown, T. E., N. B. Waechter, F. Owens, I. Howeth, and V. E. Barnes

1976 Geologic Atlas of Texas, Crystal City-Eagle Pass Sheet. Bureau of Economic Geology, The University of Texas at Austin.

Brown, T. E., N. B. Waechter, P. R. Rose, and V. E. Barnes

1974 Geologic Atlas of Texas, San Antonio Sheet. Bureau of Economic Geology, The University of Texas at Austin.

Bruseth, James E., and William A. Martin (editors) 1987 The Bird Point Island and Adams Ranch Sites: Methodological and Theoretical Contributions to North Central Texas Archaeology. Richland Creek Technical Series, Vol. II.Archaeology Research Program, Institute for the Study of Earth and Man, Southern Methodist University, Dallas.
Calhoun, Cecil A.

1999 Majolica and Faience from the Presidio Loreto Site (41VT8). Bulletin of the Texas Archeological Society 70:339-354.

Campbell, T. N.

1947 The Johnson Site: The Type Site of the Aransas Focus of the Texas Coast. Bulletin of the Texas Archeological and Paleontological Society 18:40-75.

1952 The Kent-Crane Site: A Shell Midden on the Texas Coast. Bulletin of the Texas Archeological and Paleontological Society 23:3977.

1958 Archeology of the Central Southern Sections of the Texas Coast. Bulletin of the Texas Archeological Society.27:7-46.

1976 Archaeological Investigations at the Morhiss Site, Victoria County, Texas, 1932-1940. In An Archaeological Survey of Coleto Creek, Victoria and Goliad Counties, Texas, by Anne A. Fox and Thomas R. Hester, pp. 81-85. Archaeological Survey Report No. 18. Center for Archaeological Research, The University of Texas at San Antonio.

1988 Indians of Southern Texas and Northeastern Mexico: Selected Writings of Thomas Nolan Campbell. Texas Archeological Research Laboratory, with the cooperation of the Department of Anthropology, the College of Liberal Arts, and the Institute of Latin American Studies, The University of Texas at Austin.

Campbell, T. N., and T. J. Campbell

1981 Historic Indian Groups of the Choke Canyon Reservoir and Surrounding Area, Southern Texas. Choke Canyon Series, Volume 1. Center for Archaeological Research, The University of Texas at San Antonio.

Carlson, David L., D. Gentry Steele, and A. G. Comuzzie

1984 Mammoth Excavations at the DuewellNewberry Site on the Brazos River in Texas, 1983. Current Research 1:63-64.

Castañeda, Carlos E.

1936- Our Catholic Heritage in Texas, 1519 1958 1936. 7 vols. Von Boeckmann-Jones Co., Austin.

Collins, Michael B.

1968 A Note on Broad Corner-Notched Projectile 
Points Used in Bison Hunting in Western Texas. The Bull Roarer 3(2):13-14. The University of Texas Anthropological Society, Department of Anthropology, The University of Texas at Austin.

1990 The Archaeological Sequence at Kincaid Rockshelter, Uvalde County, Texas. Transactions of the Twenty-Fifth Regional Archeological Symposium for Southeastern New Mexico and Western Texas, pp. 25-34.

1995 Forty Years of Archeology in Central Texas. Bulletin of the Texas Archeological Society 66:361-400.

1998 Early Paleoindian Components. In Wilson-Leonard: An 11,000-Year Archeological Record of Hunter-Gatherers in Central Texas, Volume I, edited and assembled by Michael B. Collins, pp. 123-159. Studies in Archeology 31. Texas Archeological Research Laboratory, The University of Texas at Austin. Archeology Studies Program, Report 10. Environmental Affairs Division, Texas Department of Transportation.

Collins, Michael B., Bruce Ellis, and Cathy Dodt-Ellis 1990 Excavations at the Camp Pearl Wheat Site (41KR243): An Early Archaic Campsite on Town Creek, Kerr County, Texas. Studies in Archeology 6. Texas Archeological Research Laboratory, The University of Texas at Austin.

Collins, Michael B., Glen L. Evans, Thomas N. Campbell, Melissa C. Winans, and Charles E. Mear

1989 Clovis Occupation at Kincaid Rockshelter, Texas. Current Research in the Pleistocene $6: 3-4$.

Collins, Michael B., Jan Guy, and Susan W. Dial

1998 The Archaic Period, 8800 to 1300 B.P. In Wilson-Leonard: An 11,000-Year Archeological Record of Hunter-Gatherers in Central Texas, Volume I, edited and assembled by Michael B. Collins, pp. 211270. Studies in Archeology 31. Texas Archeological Research Laboratory, The University of Texas at Austin. Archeology Studies Program, Report 10. Environmental Affairs Division, Texas Department of Transportation.

Collins, Michael B., Thomas R. Hester, and Pamela J. Headrick

1992 Engraved Cobbles from the Gault Site,
Central Texas. Current Research in the Pleistocene 9:3-4.

Corbin, James E.

1974 A Model for Cultural Succession for the Coastal Bend Area of Texas. Bulletin of the Texas Archeological Society 45:29-54.

1976 The Archaic of the Texas Coast. In The Texas Archaic: A Symposium, edited by Thomas R. Hester, pp. 91-97. Special Report No. 2. Center for Archaeological Research, The University of Texas at San Antonio.

Cox, Kim A., and Herman A. Smith

1988 Kent Crane Revisited. La Tierra 15(3):24-28.

Davis, Michael W., Dan K. Utley, Steve A. Tomka, and Solveig A. Turpin

1987 Continuing Cultural Resource Investigations in the Calvert Prospect: The 1986 Season. Research Report No. 95. Texas Archeological Survey, The University of Texas at Austin.

Davis, Mike, and Jim Bruseth

2000 The Fort St. Louis Archeological Project, October 1999 through Mid-February 2000. Current Archeology in Texas 2(1):14.

Day, D. William

1984 Archeological Mitigation at the Doyle Martin Site, 41LN178, and the P. I. Ridge Site, 41FT52, Leon and Freestone Counties, Texas. Document No. 82209. Espey, Huston and Associates, Inc., Austin.

Dering, Phil

1999 Earth-Oven Plant Processing in Archaic Period Economies: An Example from a Semi-arid Savannah in South-Central North America. American Antiquity 64(4):659-674.

Diamond, David D., David H. Riskind, and Steve L. Orzell

1987 A Framework for Plant Communities Classification and Conservation in Texas. Texas Journal of Science 39(3):203-221.

Dibble, David S., and Dessamae Lorrain

1968 Bonfire Shelter: A Stratified Bison Kill Site, Val Verde County, Texas. Miscellaneous Papers No. 1. Texas Memorial Museum, The University of Texas at Austin.

Ensor, H. Blaine, and Catherine S. Mueller-Wille 1988 Excavations at the Bull Pen Site, 
41BP280, Colorado River Drainage, Bastrop County, Texas. Contract Reports in Archaeology, Report Number 3. Texas State Department of Highways and Public Transportation, Highway Design Division, Austin.

Espey, Huston and Associates, Inc.

1984 Archeological Mitigation at the Doyle Martin Site, 41LN178, and the P. I. Ridge Site, 41FT52, Leon and Freestone Counties, Texas. Document No. 82209. Espey, Huston and Associates, Inc., Austin.

Fenneman, Nevin M.

1931 Physiography of Western United States. McGraw-Hill Book Company, Inc., New York.

1938 Physiography of Eastern United States. McGraw-Hill Book Company, Inc., New York.

Fields, Ross C.

1995 The Archeology of the Post Oak Savannah of East Central Texas. Bulletin of the Texas Archeological Society 66:301-330.

Fields, Ross C. (editor)

1987 Excavations at the Alley Road Site (41LN30), Jewett Mine Project, Leon County, Texas. Reports of Investigations No. 61. Prewitt and Associates, Inc., Austin.

1990 Excavations at the Charles Cox, Lambs Creek Knoll, and Buffalo Branch Sites, Jewett Mine Project, Leon and Freestone Counties, Texas. Reports of Investigations No. 70. Prewitt and Associates, Inc., Austin.

Fields, Ross C., and L. Wayne Klement

1995 Excavations at the Cottonwood Springs Site, Jewett Mine Project, Leon County, Texas. Reports of Investigations No. 102. Prewitt and Associates, Inc., Austin.

Fields, Ross C., L. Wayne Klement, C. Britt Bousman, Steve A. Tomka, Eloise F. Gadus, and Margaret A. Howard

1991 Excavations at the Bottoms, Rena Branch, and Moccasin Springs Sites, Jewett Mine Project, Freestone and Leon Counties, Texas. Reports of Investigations No. 82. Prewitt and Associates, Inc., Austin.

Fox, Anne A., and Thomas R. Hester

1976 Archaeological Survey of Coleto Creek,
Victoria and Goliad Counties, Texas. Archaeological Survey Report No. 18. Center for Archaeological Research, The University of Texas at San Antonio.

Fox, Anne A., S. L. Black, and S. James

1979 Intensive Survey and Testing of Archaeological Sites on Coleto Creek, Victoria and Goliad Counties, Texas. Archaeological Survey Report No. 67. Center for Archaeological Research, The University of Texas at San Antonio.

Fox, Daniel E.

1979 The Lithic Artifacts of Indians at the Spanish Colonial Missions, San Antonio, Texas. Special Report No. 8. Center for Archaeological Research, The University of Texas at San Antonio.

Fritz, Gayle

1975 Matagorda Bay Area, Texas: A Survey of the Archaeological and Historical Resources. Research Report No. 45. Texas Archeological Survey, The University of Texas at Austin.

Fullem, Bruce B.

1977 The Black Hopper Site. Report No. 10. State Department of Highways and Public Transportation, Highway Design Division, Austin.

Gadus E. Frances, Marie E. Blake, Martha Doty Freeman, and Karl Kibler

1999 National Register Testing of Prehistoric and Historic Sites and Survey of Placement Areas, Channel to Victoria, Calhoun and Victoria Counties, Texas. Reports of Investigations No. 121. Prewitt and Associates, Inc., Austin.

Gadus, E. Frances, Jennifer K. McWilliams, and Ross C. Fields

2001 Data Recovery Excavations at the McGuire's Garden Site (41FT425), Jewett Mine, Freestone County, Texas. Draft Report. Prewitt and Associates, Inc., Austin.

Gilmore, Kathleen Kirk

1996a San Francisco Xavier de Horcasitas Mission. In The New Handbook of Texas, Vol. 5:849. The Texas State Historical Association, Austin.

1996b San Ildefonso Mission. In The New Handbook of Texas, Vol. 5:853-854. The Texas State Historical Association, Austin. 
Goode, Glenn T

1991 Late Prehistoric Burned Rock Middens in Central Texas. In The Burned Rock Middens of Texas: An Archeological Symposium, edited by Thomas R. Hester, pp. 71-93. Studies in Archeology 13. Texas Archeological Research Laboratory, The University of Texas at Austin.

Hall, Grant D.

1981 Allens Creek: A Study in the Cultural Prehistory of the Brazos River Valley, Texas. Research Report No. 61. Texas Archeological Survey, The University of Texas at Austin.

1995a A Perspective on Some Prehistoric Cemeteries in Texas: Loma Sandia in the Regional Setting. In Archeological Investigations at the Loma Sandia Site (41LK28). A Prehistoric Cemetery and Campsite in Live Oak County, Texas, by Anna Jean Taylor and Cheryl Lynn Highley, Vol. 1, pp. 47-56. Studies in Archeology 20. Texas Archeological Research Laboratory, The University of Texas at Austin.

1995b Prehistoric Cemeteries on the Texas Central Coastal Plain: Interpretations and Hypotheses. In Archeological Investigations at the Loma Sandia Site (41LK28). A Prehistoric Cemetery and Campsite in Live Oak County, Texas, by Anna Jean Taylor and Cheryl Lynn Highley, Vol. 2, pp. 633-647. Studies in Archeology 20. Texas Archeological Research Laboratory, The University of Texas at Austin.

Hall, Grant D., Stephen L. Black, and Carol Graves 1981 The Archaeological Investigations at Choke Canyon Reservoir, South Texas: The Phase I Findings. Choke Canyon Series: Vol. 5. Center for Archaeological Research, The University of Texas at San Antonio.

Hall, Grant D., Thomas R. Hester, and Stephen L. Black

1986 The Prehistoric Sites at Choke Canyon Reservoir, South Texas: Results of Phase II Archaeological Investigations. Choke Canyon Series: Volume 10. Center for Archaeological Research, The University of Texas at San Antonio.

Henderson, Jerry, and Glenn T. Goode

1991 Pavo Real: An Early Paleoindian Site in
South-Central Texas. Current Research in the Pleistocene 8:26-28.

Hester, Thomas R.

1976 Late Pleistocene Aboriginal Adaptations in Texas. In Papers on Paleo-Indian Archaeology in Texas: I, pp. 1-10. Special Report No. 3. Center for Archaeological Research. The University of Texas at San Antonio.

1980 A Survey of Paleo-Indian Remains Along the Texas Coast. In Papers on the Archaeology of the Texas Coast, edited by L. Highley and T. R. Hester, pp. 1-22. Special Report 11. Center for Archaeological Research, The University of Texas at San Antonio.

1989 Historic Native American Populations. In From the Gulf to the Rio Grande: Human Adaptation in Central, South, and Lower Pecos, Texas, by Thomas R. Hester, Stephen L. Black, D. Gentry Steele, Ben W. Olive, Anne A. Fox, Karl J. Reinhard, and Leland C. Bement, pp. 77-84. Research Series No. 33. Arkansas Archeological Survey, Fayetteville.

1995 The Prehistory of South Texas. Bulletin of the Texas Archeological Society 66:427459.

1999 Artifacts, Archeology, and Cabeza de Vaca in Southern Texas and Northeastern Mexico. Bulletin of the Texas Archeological Society 70:17-28.

Hester, Thomas R., and Michael B. Collins

1969 Burials from the Frisch Auf! Site: 41FY2 Texas Journal of Science 20(3):261-272.

Hindes, Kay V., Anne E. Fox, and E. H. Schmiedlin 1999 An Overview of Test Excavations and Documentary Research at 41VT10, the Tonkawa Bank Site, Victoria City Park, Victoria Texas. Bulletin of the Texas Archeological Society 70:79-96.

Houk, Brett A., Steve Tomka, Britt Bousman, C. K. Chandler, Bruce Moses, Marcie Renner, and Mike Lyons

1997 The Greenbelt Core: A Polyhedral Blade Core from San Antonio, Texas. Current Research in the Pleistocene 14:104-106.

Huebner, Jeffery A.

1988 The Archaeology of Blue Bayou: A Late Prehistoric and Archaic Mortuary Site, 
Victoria County, Texas. M.A. thesis, Department of Anthropology, The University of Texas at San Antonio.

1991 Late Prehistoric Bison Populations in Central and South Texas. Plains Anthropologist 36(137):343-358.

Jelks, Edward B.

1962 The Kyle Site: A Stratified Central Texas Aspect Site in Hill County, Texas. Archaeology Series No. 5. Department of Anthropology, The University of Texas at Austin.

Johnson, LeRoy, Jr.

1994 The Life and Times of Toyah-Culture Folk As Seen from the Buckhollow Encampment, Site 31KM16, of Kimble County, Texas. Office of the State Archeologist Report 38. Texas Department of Transportation and Texas Historical Commission, Austin.

1995 Past Cultures and Climates at Jonas Terrace: 41ME29 of Medina County, Texas. Report No. 40. Office of the State Archeologist, Texas Historical Commission, Austin.

Johnson, LeRoy, and Glenn T. Goode

1994 A New Try at Dating and Characterizing Holocene Climates, as Well as Archeological Periods, on the Eastern Edwards Plateau. Bulletin of the Texas Archeological Society 65:1-51.

Johnson, LeRoy, Jr., Dee Ann Suhm, and Curtis D. Tunnell

1962 Salvage Archeology of Canyon Reservoir: The Wunderlich, Footbridge, and Oblate Sites. Bulletin No. 5. Texas Memorial Museum, The University of Texas at Austin.

Katz, Paul R.

1987 Archaeological Mitigation at 41BX300, Salado Creek Watershed, South-Central Texas. Archaeological Survey Report No. 130. Center for Archaeological Research, The University of Texas at San Antonio.

Keller, John E., and L. Janice Campbell (compilers) 1984 Patterns in Prehistoric Settlement: Examining the Distribution of Sites in a Portion of the Colorado River Valley, The Colorado Coastal Plains Project, Fayette and Colorado Counties, Texas. Report of Investigations No. 83-11. New World Research, Inc., Pollock, Louisiana.
Kelley, J. C., and T. N. Campbell

1942 What are the Burnt Mounds of Texas? American Antiquity 7(3):319-322.

Kerr, Anne C., and Susan W. Dial

1998 Statistical Analysis of Unfluted Lanceolate and Early Bifurcate Stem Projectile Points. In Wilson-Leonard: An 11,000-Year Archeological Record of Hunter-Gatherers in Central Texas, Volume II, edited and assembled by Michael B. Collins, pp. 447-505. Studies in Archeology 31. Texas Archeological Research Laboratory, The University of Texas at Austin. Archeology Studies Program, Report 10. Environmental Affairs Division, Texas Department of Transportation.

Kibler, Karl W., and Ann M. Scott

2000 Archaic Hunters and Gatherers of the Balcones Canyonlands: Data Recovery Excavations at the Cibolo Crossing Site (41BX377), Camp Bullis Military Reservation, Bexar County, Texas. Reports of Investigations No. 126. Prewitt and Associates, Inc., Austin.

Kleinbach, Karl, Gemma Mehalchick, James T. Abbott, and J. Michael Quigg

1995 Other Analyses. In NRHP Significance Testing Of 57 Prehistoric Archeological Sites On Fort Hood, Texas, Volume II, edited by James T. Abbott and W. Nicholas Trierweiler, pp. 765-842. Archeological Resource Management Series, Research Report No. 34. United States Army Fort Hood.

Kotter, Steven M., Patience E. Patterson, Dan K. Utley, and Henry B. Moncure

1991 Final Report of Cultural Resource Investigations at the Cummins Creek Mine, Fayette County, Texas. Studies in Archeology 11. Texas Archeological Research Laboratory, The University of Texas at Austin.

LBJ School of Public Affairs

1978 Preserving Texas' Natural Heritage. Project Report 31. Natural Heritage Policy Research Project, The University of Texas at Austin.

Lukowski, Paul D.

1988 Archaeological Investigations at 41BX1, Bexar County, Texas. Archaeological Survey Report No. 135. Center for Archaeological Research, The University of Texas at San Antonio. 
Mallouf, Michael G.

1979 Archeological Investigations at Lake Limestone. Research Report No. 71. Texas Archeological Survey, The University of Texas at Austin.

Mallouf, Robert J., Daniel E. Fox, and Alton Briggs 1973 An Assessment of the Cultural Resources of Palmetto Bend Reservoir, Jackson County, Texas. Archeological Survey Report Number 11. Texas Historical Commission and Texas Water Development Board.

McGraw, A. Joachim, John W. Clark Jr., and Elizabeth A. Robbins

1991 A Texas Legacy, The Old San Antonio Road and the Caminos Reales, A Tricentennial History, 1691-1991. Texas Department of Transportation, Environmental Affairs Department, Austin.

McGregor, Daniel E., and James E. Bruseth (editors) 1987 Hunter-Gatherer Adaptations Along the Prairie Margin: Site Excavations and Synthesis of Prehistoric Archaeology. Richland Creek Technical Series, Vol. III. Archaeology Research Program, Institute for the Study of Earth and Man, Southern Methodist University, Dallas.

McGraw, A. Joachim, and Kay Hindes

1987 Chipped Stone and Adobe: A Cultural Resources Assessment of the Proposed Applewhite Reservoir, Bexar County, Texas. Archeological Survey Report No. 163. Center for Archeological Research, The University of Texas at San Antonio.

McKinney, Wilson W.

1981 Early Holocene Adaptations in Central and Southwestern Texas: The Problem of the Paleoindian-Archaic Transition. Bulletin of the Texas Archeology Society 52:91-120.

Meltzer, David J., and Michael R. Bever

1995 Paleoindians of Texas: An Update on the Texas Clovis Fluted Point Survey. Bulletin of the Texas Archeological Society $66: 47-81$.

Newcomb, W. W., Jr.

1961 The Indians of Texas. University of Texas Press, Austin.

1993 Historic Indians of Central Texas. Bulletin of the Texas Archeological Society 64:1-63.
Peterson, Fredrick A.

1965 The Erwin's Bridge Site at Somerville Reservoir, Burleson County, Texas. Texas Archeological Salvage Project, The University of Texas at Austin.

Prewitt, Elton R.

1981 Cultural Chronology in Central Texas. Bulletin of the Texas Archeological Society 52:65-89.

1985 From Circleville to Toyah: Comments on Central Texas Chronology. Bulletin of the Texas Archeological Society 54:201238.

Prewitt, Elton R., Susan V. Lisk, and Margaret A. Howard

1986 National Register Assessments of the Swan Lake Site, 41AS16, on Copano Bay, Aransas County, Texas. Reports of Investigations No. 56. Prewitt and Associates, Inc., Austin.

Proctor, C. V., Jr., T. E. Brown, J. H. McGowen, and N. B. Waechter

1981 Geologic Atlas of Texas, Austin Sheet. Bureau of Economic Geology, The University of Texas at Austin.

Proctor, C. V., Jr., T. E. Brown, N. B. Waechter, S. Aronow, M. K. Pieper, and V. E. Barnes

1979 Geologic Atlas of Texas, Seguin Sheet. Bureau of Economic Geology, The University of Texas at Austin.

Proctor, C. V., Jr., J. H. McGowen, and W. T. Haenggi 1970 Geologic Atlas of Texas, Waco Sheet. Bureau of Economic Geology, The University of Texas at Austin.

Ricklis, Robert A.

1988 Archeological Investigations at the McKinzie Site (41NU221) Nueces County, Texas: Description and Contextual Interpretations. Bulletin of the Texas Archeological Society 58:1-76.

1989 Historical Cultural Ecology of the Karankawan Indians of the Central Texas Coast: A Case Study in the Roots of Adaptive Change. Ph.D. dissertation, Department of Geography, The University of Texas at Austin.

1995 Prehistoric Occupation of the Central and Lower Texas Coast: A Regional Overview. Bulletin of the Texas Archeological Society 66:265-300. 
1996 The Karankawa Indians of Texas. An Ecological Study of Cultural Tradition and Change. University of Texas Press, Austin.

1999 The Spanish Colonial Missions of Espiritu Santo (41GD1) and Nuestra Señora del Rosario (41GD2), Goliad, Texas: Exploring Patterns of Ethnicity, Interaction, and Acculturation. Bulletin of the Texas Archeological Society 70:132-168.

Robinson, David G., and Solveig A. Turpin

1993 Hunter-Gatherer Mobility and Settlement in the Brazos Uplands: Archeology in the Calvert Mine, Robertson County, EastCentral Texas. Studies in Archeology 14. Texas Archeological Research Laboratory, The University of Texas at Austin.

Roemer, Erwin, Jr., and Shawn Bonath Carlson 1987 Excavations at 41BU16: State Highway 21 at the Brazos River, Burleson County, Texas. Contract Reports in Archaeology, Report Number 1. Texas State Department of Highways and Public Transportation, Highway Design Division, Austin.

Rogers, Robert

1993 Data Recovery of Three Prehistoric Sites at the Gibbons Creek Third Five-Year Mine Permit Area, Grimes County, Texas. Document No. 910529. Espey, Huston and Associates, Inc., Austin.

1994 Excavations at Site 41GM224 in Gibbons Creek Lignite Mine Permit 38A Area, Grimes County, Texas. Document No. 930476. Espey, Huston and Associates, Inc., Austin.

1995 Excavations at Sites 41GM166, 41GM281 and 41GM282 at the Gibbons Creek Lignite Mine, Grimes County, Texas. Document No. 940611. Espey, Huston and Associates, Inc., Austin.

1997 National Register Testing at Site 41LE120, Lee County, Texas. Document No. 970348. Espey, Huston and Associates, Inc., Austin.

1999 Excavations at the Walleye Creek Site (41LE57), Lee County, Texas. Document No. 981670. Espey, Huston and Associates, Inc., Austin.

Rogers, Robert, and Steve Kotter

1995 Archaeological Investigations at the Chesser Site (41LE59), Lee County, Texas.
Document No. 950209. Espey, Huston and Associates, Inc., Austin.

Scott, Robert F., IV, and Daniel E. Fox

1982 Excavations at Sites 41LK31/32 and $41 L K 202$ in the Choke Canyon Reservoir, South Texas. Choke Canyon Series: Volume 8. Center for Archaeological Research, The University of Texas at San Antonio.

Sellards, E. H.

1940 Pleistocene Artifacts and Associated Fossils from Bee County, Texas. Bulletin of the Geological Society of America 51:1627-1658.

Shelby, C. A., M. K. Pieper, S. Aronow, W. L. Fisher, J. H. McGowen, and V. E. Barnes

1968a Geologic Atlas of Texas, Beaumont Sheet. Bureau of Economic Geology, The University of Texas at Austin.

Shelby, C. A., M. K. Pieper, and A. C. Wright

1968b Geologic Atlas of Texas, Palestine Sheet. Bureau of Economic Geology, The University of Texas at Austin.

Shum, Raymond W.

1980 The La Paloma Mammoth Site, Kenedy County, Texas. In Papers on the Archaeology of the Texas Coast, edited by Lynn Highley and Thomas R. Hester, pp. 79104. Special Report No. 11. Center for Archaeological Research, The University of Texas at San Antonio.

Skelton, Duford W.

1977 Archeological Investigations at the Fayette Power Project, Fayette County, Texas. Research Report No. 60. Texas Archeological Survey, The University of Texas at Austin.

Sorrow, William M.

1969 Archeological Investigations at the John Ischy Site: A Burned Rock Midden in Williamson County, Texas. Papers of the Texas Archeological Salvage Project No. 18. The University of Texas at Austin.

Spearing, Darwin

1991 Roadside Geology of Texas. Mountain Press Publishing Company, Missoula, Montana.

Steele, D. Gentry

1986 Analysis of Vertebrate Faunal Remains. in The Clemente and Herminia Hinojosa Site, 41JW8: A Toyah Horizon Campsite 
in Southern Texas, by Stephen L. Black, pp. 108-136. Special Report No. 18. Center for Archaeological Research, The University of Texas at San Antonio.

Steele, D. Gentry, and C. A. Hunter

1986 Analysis of Vertebrate Faunal Remains from 41MC222 and 41MC296, McMullen County, Texas. In The Prehistoric Sites at Choke Canyon Reservoir, South Texas: Results of Phase II Archaeological Investigations, by G. D. Hall, T. R. Hester, and S. L. Black, pp. 452-502. Choke Canyon Series: Volume 10. Center for Archaeological Research, The University of Texas at San Antonio.

Story, Dee Ann

1968 Archeological Investigations at Two Central Texas Gulf Coastal Sites. Report Number 13. State Building Commission Archeological Program, Austin.

1985 Adaptive Strategies of Archaic Cultures of the West Gulf Coastal Plain. In Prehistoric Food Production in North America, edited by R. I. Ford, pp. 19-56. Anthropological Papers 75. Museum of Anthropology, University of Michigan, Ann Arbor.

1990 Cutural History of the Native Americans. In The Archeology and Bioarcheology of the Gulf Coastal Plain, by Dee Ann Story, Janice A. Guy, Barbara A. Burnett, Martha Doty Freeman, Jerome C. Rose, D. Gentry Steele, Ben W. Olive, and Karl J. Reinhard, pp. 163-366. Research Series No. 38. Arkansas Archeological Survey, Fayetteville.

Suhm, Dee Ann

1960 A Review of Central Texas Archeology. Bulletin of the Texas Archeological Society 29:63-107.

Suhm, Dee Ann, Alex D. Krieger, and Edward B. Jelks 1954 An Introductory Handbook of Texas Archeology. Bulletin of the Texas Archeological Society, Vol. 25.

Takac, Paul R.

1991 Underwater Excavations at Spring Lake: A Paleoindian Site in Hays County, Texas. Current Research in the Pleistocene 8:46-48.

Taylor, Anna Jean, and Cheryl Lynn Highley 1995 Archeological Investigations at the Loma Sandia Site (41LK28). A Prehistoric Cem- etery and Campsite in Live Oak County, Texas, Vol. 1 and 2. Studies in Archeology 20. Texas Archeological Research Laboratory, The University of Texas at Austin.

Thoms, Alston V., and Steven W. Ahr

1996 Archaeological Studies at Birch Creek Unit and Yegua Creek Fishing-Access Area, Lake Somerville State Park, Burleson County, Texas, Interim Report, September 1996. Center for Environmental Archaeology, Texas A\&M University, College Station.

Thoms, Alston V., David D. Kuehn, Ben W. Olive, John E. Dockall, Patricia A. Clabaugh, and Rolfe Mandel

1996 Early and Middle Holocene Occupations at the Richard Beene Site: The 1995 Southern Texas Archaeological Association Field School Project. La Tierra 23(4):8-36.

Thoms, A. V., and R. D. Mandel

1991 The Richard Beene Site: A Deeply Stratified Paleoindian to Late Prehistoric Occupation in South-Central Texas. Current Research in the Pleistocene 9:42-44.

Tomka, Steve A., Timothy K. Perttula, and Robert J. Hard

1997 Archaeology of the Rio Grande and Central Coastal Plains, Texas: A Planning Document (draft). Archaeological Survey Report No. 266. Center for Archaeological Research, The University of Texas at San Antonio.

Toomey III, Rickard S., Michael D. Blum, and Salvatore Valastro Jr.

1993 Late Quaternary Climates and Environments of the Edwards Plateau, Texas. Global and Planetary Change 7:299-320.

Waechter, N. B., F. E. Lozo Jr., and V. E. Barnes 1977 Geologic Atlas of Texas, Del Rio Sheet. Bureau of Economic Geology, The University of Texas at Austin.

Walter, Tamra L.

1999 A Preliminary Report of the 1997 TAS Field School Excavations in Area A at Mission Espiritu Santo de Zuniga (41VT11), Victoria County, Texas. Bulletin of the Texas Archeological Society 70:97-121.

Wandsnider, L.

1997 The Roasted and the Boiled: Food 
Composition and Heat Treatment with Special Emphasis on Pit-Hearth Cooking. Journal of Anthropological Archaeology $16: 1-48$.

Weinstein, Richard A.

1992 Archaeology and Paleogeography of the Lower Guadalupe River/San Antonio Bay Region: Cultural Resources Investigations Along the Channel to Victoria, Calhoun and Victoria Counties, Texas. Coastal Environments, Inc., Baton Rouge.

Weir, Frank A.

1976 The Central Texas Archaic. Ph.D. dissertation, Department of Anthropology,
Washington State University, Pullman.

Wesolowsky, Al B., Thomas R. Hester, and Douglas R. Brown

1976 Archeological Investigations at the Jetta Court Site (41TV151) Travis County, Texas. Bulletin of the Texas Archeological Society 47:25-87.

Willey, Gordon R., and Philip Phillips

1958 Method and Theory in American Archaeology. University of Chicago Press, Chicago.

Wilson, E. W.

1930 Burnt Rock Mounds of Southwest Texas. Bulletin of the Texas Archaeological and Paleontological Society 2:59-63. 
APPENDIX A: GLOSSARY OF TECHNICAL TERMS 
THIS PAGE INTENTIONALLY LEFT BLANK 
Adze: Tool whose cutting edge is at a right angle to the handle and that is used in working wood.

Arrow point: Point used to tip an arrow, which is propelled by a bow.

Biface: Piece of conchoidally fracturing stone that has had flakes removed from both faces to create a tool.

Burin: Chisel-like tool presumed to have been used in working bone, antler, and wood.

Dart point: Point used to tip a throwing spear or dart, which is propelled by an atlatl.

Debitage: Debris generated by the removal through percussion or pressure of flakes, chips, and chunks to make stone tools.

Fill section: Introduced fill used to elevate the approaches to a bridge above the surrounding terrain.

Flake: Generally thin piece of conchoidally fracturing stone with a positive bulb of percussion showing that it was removed from the parent piece by percussion or pressure.

Gouge: Generally thick, bifacially modified tool presumed to have been used like an adze.

Grog: Crushed fired clay added as temper to clay used in making ceramic vessels.

Impact Evaluation: Onsite inspection documenting existing damage or other conditions that may preclude the presence of intact archeological deposits within the project area for a proposed Transportation Activity.

Mano: Handheld stone used, usually with a metate, to grind plant parts such as seeds.

Megafauna: Very large animal.

Metate: Anvil of stone used, usually with a mano, to grind plant parts such as seeds.

Midden: Accumulation of occupational debris, particularly organic remains.

Projectile point: Inclusive term for arrow and dart points.

Scraper: Tool with generally thick, unifacially modified edges used to work hides, bone, and wood.

Sherd: A piece of broken pottery.

Survey: Fieldwork to locate archeological remains within the project area for a proposed Transportation Activity, including on-foot examination of the surface, shovel testing, and trenching by mechanical means where appropriate.

Survey with Geoarcheological Evaluation: Fieldwork to locate archeological remains within the project area for a proposed Transportation Activity, including examining and record trench walls or other exposures by a geomorphologist, quaternary geologist, physical geographer, soil scientist, or archeologist with the formal training and experience to apply the principles of geology to the evaluation of the pedological, stratigraphic, geomorphic, anthrogenic, and other conditions affecting the physical integrity of archeological deposits and the interpretation of archeological materials. 
Temper: Nonplastic materials added to clay to decrease the risk of cracking when firing ceramic vessels.

Transportation Activity: any proposed project involving the development, design, construction, or maintenance of the state's intermodal transportation system. 
APPENDIX B: LETTERS AND LETTER REPORTS FOR IMPACT EVALUATIONS AND SURVEYS 
THIS PAGE INTENTIONALLY LEFT BLANK 
The interim reports for the Impact Evaluations and Surveys are on the included CD-ROM. Authors of the reports include Amy M. Holmes, Ross C. Fields, E. Frances Gadus, and Christopher W. Ringstaff. 
THIS PAGE INTENTIONALLY LEFT BLANK 